\title{
Penyelesaian tenurial perkebunan kelapa sawit di kawasan hutan untuk kepastian investasi dan keadilan
}

Lukas R Wibowo

Ismatul Hakim

Heru Komarudin

Dewi Ratna Kurniasari

Donny Wicaksono

Beni Okarda 

Working Paper 247

\title{
Penyelesaian tenurial perkebunan kelapa sawit di kawasan hutan untuk kepastian investasi dan keadilan
}

\author{
Lukas R Wibowo \\ Pusat Penelitian dan Pengembangan Sosial Ekonomi Kebijakan dan Perubahan Iklim (P3SEKPI), Badan Penelitian \\ Pengembangan dan Inovasi (BLI), Kementerian Lingkungan Hidup dan Kehutanan (KLHK) \\ Ismatul Hakim \\ P3SEKPI, BLI, KLHK \\ Heru Komarudin \\ CIFOR \\ Dewi Ratna Kurniasari \\ P3SEKPI, BLI, KLHK \\ Donny Wicaksono \\ P3SEKPI, BLI, KLHK \\ Beni Okarda \\ CIFOR
}


Working Paper 247

(C) 2019 Pusat Penelitian Kehutanan Internasional (CIFOR)

(c) (1) Materi dalam publikasi ini berlisensi di dalam Creative Commons Attribution 4.0 International (CC BY 4.0), http://creativecommons.org/licenses/by/4.0/

DOI: 10.17528/cifor/007337

Wibowo LR, Hakim I, Komarudin H, Kurniasari DR, Wicaksono D dan Okarda B. 2019. Penyelesaian tenurial perkebunan kelapa sawit di kawasan hutan untuk kepastian investasi dan keadilan. Working Paper 247. Bogor, Indonesia: CIFOR.

\section{CIFOR}

Jl. CIFOR, Situ Gede

Bogor Barat 16115

Indonesia

$\mathrm{T}+62(251) 8622-622$

F +62 (251) 8622-100

E cifor@cgiar.org

\section{cifor.org}

Kami ingin berterima kasih kepada para donatur yang telah mendukung penelitian ini melalui kontribusinya terhadap Dana CGIAR. Untuk daftar donor dapat dilihat dalam: https://www.cgiar.org/funders/

Pandangan yang diungkapkan dalam publikasi ini berasal dari penulis dan bukan merupakan pandangan CIFOR, para penyunting, lembaga asal penulis atau penyandang dana maupun para peninjau buku. 


\section{Daftar isi}

Ucapan terima kasih $\quad$ v

English summary $\quad$ vi

1 Pendahuluan 1

1.1 Latar belakang 1

1.2 Tujuan dan metode 2

2 Perkebunan kelapa sawit dan kawasan hutan 4

2.1 Sejarah perkembangan investasi kehutanan dan perkebunan: Titik berat pada aspek
politik dan ekonomi

$\begin{array}{lll}2.2 & \text { Perkebunan kelapa sawit yang berasal dari pelepasan kawasan hutan } & 6\end{array}$

3 Praktik dan strategi pengadaan dan penguasaan lahan untuk perkebunan sawit $\quad 8$

3.1 Proses investasi dan perizinan perkebunan kelapa sawit $\quad 8$

$\begin{array}{llr}3.2 & \text { Perkebunan kelapa sawit terindikasi dalam kawasan hutan } & 10\end{array}$

3.3 Mengapa perkebunan kelapa sawit di kawasan hutan terjadi? $\quad 11$

$\begin{array}{ll}\text { 3.4 Praktik dan strategi masyarakat dalam penguasaan lahan } & 15\end{array}$

4 Perkembangan perkebunan kelapa sawit dan permasalahan tenurial di Kalimantan Tengah 19

4.1 Perkembangan perkebunan kelapa sawit di Kalimantan Tengah 19

$\begin{array}{lll}4.2 & \text { Peta konflik tenurial perkebunan kelapa sawit } 20\end{array}$

5 Perkembangan perkebunan kelapa sawit dan permasalahan tenurial di Kalimantan Barat 27

$\begin{array}{lll}5.1 & \text { Perkembangan perkebunan kelapa sawit di Kalimantan Barat } & 27\end{array}$

5.2 Peta konflik tenurial perkebunan kelapa sawit 28

6 Bagaimana pandangan para pihak terhadap perkebunan kelapa sawit di dalam kawasan hutan? $\quad 32$

7 Kebijakan penyelesaian penguasaan perkebunan kelapa sawit dalam kawasan hutan 33

7.1 Pelepasan dan tukar menukar kawasan hutan 34

7.2 Pola penyelesaian penguasaan dan pemanfaatan tanah dalam kawasan hutan oleh masyarakat 35

$\begin{array}{lll}7.3 & \text { Kebijakan terkait lainnya } & 42\end{array}$

7.4 Kebijakan penyelesaian masalah tenurial di tingkat daerah 43

7.5 Kebijakan dan prospek penyelesaian masalah tenurial ke depan $\quad 44$

8 Evaluasi implementasi kebijakan penyelesaian tenurial perkebunan kelapa sawit 45

8.1 Pelepasan atau tukar menukar kawasan $\quad 45$

8.2 Tanah Objek Reforma Agraria (TORA) 46

8.3 Perhutanan sosial $\quad 48$

8.4 Amnesti tanah: Opsi penyelesaian tenurial 49

9 Kesimpulan dan rekomendasi $\quad 51$

$\begin{array}{ll}\text { Daftar pustaka } & 53\end{array}$ 


\section{Daftar gambar dan tabel}

\section{Gambar}

1 Sebaran, luas dan produksi perkebunan kelapa sawit di berbagai provinsi

2 Luas kawasan hutan yang dilepaskan untuk perkebunan berdasarkan provinsi (Oktober 2018) 6

3 Diagram alir proses perolehan perizinan perkebunan dan persetujuan usaha perkebunan kelapa sawit

4 Akar masalah ekspansi perkebunan sawit dalam kawasan hutan

5 Penilaian responden terhadap kebijakan penyelesaian perkebunan kelapa sawit di kawasan hutan dari 3 periode pemerintahan yang berbeda $(n=86)$

6 Penyebab ekspansi sawit di kawasan hutan (Data diolah 2017; $\mathrm{n}=86$ )

7 Faktor lain dari ekspansi perkebunan kelapa sawit dalam kawasan hutan 15

8 Sebaran dan luasan kawasan hutan Provinsi Kalimantan Tengah

9 Perkembangan luas dan produksi perkebunan kelapa sawit rakyat, negara dan swasta tahun 2015-2017 di Provinsi Kalimantan Tengah

10 Perkembangan investasi di Provinsi Kalimantan Tengah (triliun Rp)

11 Dinamika konflik ruang dan keterlanjuran perkebunan kelapa sawit

12 Areal HGU perkebunan kelapa sawit di kawasan hutan dan izin pengelolaan hutan di Provinsi Kalimantan Tengah

13 Peta perkebunan kelapa sawit dalam kawasan hutan di Provinsi Kalimantan Tengah

13 Peta perkebunan kelapa sawit dalam kawasan hutan di Provinsi Kalimantan Tengah

15 Sebaran perkebunan kelapa sawit rakyat di Kabupaten (a) Kotawaringin Barat dan (b) Pulang Pisau

16 Rencana dan realisasi pembangunan perkebunan kelapa sawit antara tahun 2008 sampai 2025 di Provinsi Kalimantan Barat

17 Perkembangan luas dan produksi perkebunan kelapa sawit yang dikelola oleh perusahaan negara, swasta dan rakyat dari tahun 2015 sampai 2017 di Provinsi Kalimantan Barat

18 Peta perkebunan kelapa sawit dalam kawasan hutan di Provinsi Kalimantan Barat

19 Peta perkebunan kelapa sawit dalam kawasan hutan dan TORA di Kabupaten Landak, Provinsi Kalimantan Barat

\section{Tabel}

1 Kawasan hutan menurut TGHK (1984) 5

2 Jumlah unit dan luas perkebunan termasuk perkebunan kelapa sawit dalam kawasan hutan $\quad 10$

3 Luas perkebunan kelapa sawit rakyat di Kabupaten Kotawaringin Barat 25

4 Luas perkebunan kelapa sawit rakyat di Kabupaten Pulang Pisau 25

5 Sumber TORA sesuai SK Menteri Lingkungan Hidup dan Kehutanan No. 180/2017 dan revisi perubahannya

6 Luas areal indikatif TORA di Provinsi Kalimantan Barat dan Kalimantan Tengah 38

7 Sebaran kebun sawit di kawasan hutan di Kalimantan Tengah di berbagai sumber TORA $\quad 39$

8 Sebaran sumber TORA di setiap kabupaten di Provinsi Kalimantan Tengah dan Kalimantan Barat 


\section{Ucapan terima kasih}

Penulis menyampaikan terima kasih kepada Dr. Syaiful Anwar sebagai Kepala Pusat Litbang Sosial Ekonomi Kebijakan dan Perubahan Iklim (P3SEKPI) yang telah memfasilitasi izin penelitian dan memberikan masukan atas hasil penelitian. Penulis juga berterima kasih kepada Dr. Pablo Pacheco sebagai team leader proyek penelitian Governing Oil Palm Landscapes for Sustainability (GOLS) atas arahan dan dukungan terhadap kerjasama penelitian antara CIFOR dengan P3SEKPI. Terima kasih juga disampaikan kepada Dr. Donald Tambunan dari USAID yang telah memfasilitasi kegiatan penelitian ini.

Tidak lupa kami sampaikan terima kasih kepada seluruh nara sumber baik yang mewakili instansi pemerintah di pusat dan daerah, perusahaan, akademisi, lembaga swadaya masyarakat dan asosiasi. Penulis sangat berhutang budi atas kesediaan para nara sumber untuk berbagi informasi dan pengetahuan melalui wawancara individu. Bahan-bahan analisis dan usulan rekomendasi yang tertuang dalam laporan ini juga didasarkan pada hasil penelitian lapangan, sintesis hasil diskusi kelompok terfokus dan lokakarya dengan tema "Kepastian Tenurial dan Optimalisasi Dana Sawit dalam Rangka Mendorong Praktik-praktik Pengelolaan Sawit Berkelanjutan” yang diselenggarakan pada 4 April 2018 di Palangka Raya dan pada 9 Mei 2018 di Pontianak, serta lokakarya dengan tema "Linking Science to Policy: Peran Penelitian di dalam Penyelesaian Tenurial Sawit di Kawasan Hutan" pada 22 November 2018 di Bogor.

Penulis juga berhutang budi kepada rekan-rekan tim peneliti dari P3SEKPI dan CIFOR yang telah memberikan masukan sejak tahap perancangan dan penyusunan metode sampai tahap analisis dan penulisan. Penelitian ini merupakan bagian dari kegiatan penelitian Governing Oil Palm Landscapes for Sustainability (GOLS) yang dilaksanakan secara kolaborasi antara P3SEKPI dan CIFOR dengan pendanaan dari USAID dalam Program Terrestrial Biodiversity. 


\section{English summary}

Despite its large contribution to the Indonesian economy, the palm oil sector has had to contend with illegal plantations that overlap state forest lands, making actors concerned face legal hurdles in getting their plantations certified and considered sustainable. Of 14.03 million ha of palm oil plantations, around $21 \%$ or 2.5 million ha appear to occupy state forest lands and are considered illegal according to prevailing regulations. Smallholder plantations in trouble with the law constitute 1.7 million ha, while another 800,000 ha are controlled by companies. In resolving these tenure conflicts, the government has already put in place some policies to give companies the opportunity to obtain permission from the Ministry of Environment and Forestry for forest conversion or land swaps. These policies also grant local communities land ownership through agrarian reform or greater use rights to land through social forestry schemes. The aim is to create a good climate for investment and satisfy equality principles for people.

The paper aims to promote better understanding as to why and how these tenure issues occur and to assess how different actors use their strategies for controlling state forest land, by either legal or illegal means. It also assesses the implementation of policies already in place such as those that deal with forest conversion and land swap, agrarian reform and social forestry, and aims to resolve these tenure issues by identifying the challenges that impede the effective implementation of the policies. Based on the field observation and stakeholder input, this paper offers some policy options for resolving tenure issues.

Research - on which this paper is based - used various data collection and analysis methods. Drawing on case studies in Central Kalimantan and West Kalimantan, we first review the history and give updates on the development of oil palm plantations in the two provinces and discuss the strategies used by companies and local communities to take control over lands. With the help of spatial imagery analysis, we present the extent and spatial distribution of overlap between oil palm plantations and state forest areas, corroborating previous assumptions on the magnitude of the tenure case. We analyzed relevant secondary literature and government as well as company documents and collected primary data through in-depth as well as semistructured interviews with 40 reviewees and 86 respondents, respectively, concerned with issues around tenure, land, forestry and the oil palm industry. In order to better understand how various stakeholders view the tenure and oil palm issues and to solicit input on how existing policies can be made effective in resolving the tenure issues, we engaged participants representing various groups at national, sub-national and local levels in a series of focus group discussions and at one national workshop.

The paper identifies some reasons why oil palm plantations were established illegally on state forest land. Maladministration, lack of compliance with licensing procedure, lack of coordination and legal disputes over forest areas between the Ministry of Environment and Forestry and local (provincial and district) governments have mainly been responsible for the tenure case. In addition, incomplete forest area gazettement; people's encroachment over state forest areas, jealously motivated by the inequality of power, authority and ownership over land; ineffective implementation of the policies for forest conversion and land swap; and the slow pace of conflict resolution have all contributed to the continued illegal cases.

Considering lessons learned from the unsuccessful implementation of policies in the past, the paper argues that if tenure issues around oil palm plantations and state forest land were to be resolved effectively, it is important that we build 'no-gray' areas that prevent actors from doing profitable and legal business in the oil palm sector, creating certainty for investment and justice for smallholders. Phased but stringent approaches are needed to make sure that all companies whose plantations are 
already located on state forest land obtain legal forest conversion permits from the ministry. Priority should be given, however, to those companies highly committed to applying good agricultural practices and preventing further deforestation and adverse social impacts.

Similarly, smallholders whose plantations have illegally been developed on state forest land are given a chance to clear their status of lands through schemes called designated land for agrarian reform or Tanah Objek Reforma Agraria (TORA) or social forestry. The TORA scheme has been intensively recognized by the government as an effective means to giving local people greater access to and ownership of lands. It is, however, important that we take account of the heterogeneous typology of smallholders when addressing tenure issues involving farmers or local people. This is to ensure that policy implementation reaches the right target. The discrepancy between allocated lands under TORA and the spatial distribution of smallholder oil palm plantations across the provinces also need to be taken into account in the coming map update.

In addition, a new regulation concerning the usage of or rental scheme regarding state forest areas needs to be introduced to make sure that the state would not lose revenue and that involved actors would be held responsible for illegally encroaching state forest areas by paying compensation. While strict law enforcement could be a final instrument to resolve the tenure issues, land amnesty by giving forgiveness to those who depend heavily for their livelihoods on encroached lands, applied in combination with existing policies, could be considered a breakthrough. 


\section{Pendahuluan}

\subsection{Latar belakang}

Perluasan perkebunan kelapa sawit dengan cepat menjadi fenomena global (Colchester \& Chao, 2011). Proses produksi, pengolahan dan perdagangan minyak sawit saat ini telah berkembang menjadi jaringan kompleks yang melibatkan beragam aktor, mulai dari petani kecil, perusahaan perkebunan, industri pengolahan, pemerintah di berbagai tingkat, lembaga swadaya masyarakat dan lainnya. Jaringan tersebut membentuk tata kelola polisentris di berbagai tingkat dan melibatkan berbagai pelaku dengan kewenangannya, yang terikat oleh hubungan global-lokal (Arts, Leroy, \& van Tatenhove, 2006; Colchester \& Chao, 2011) dan berbagai inisiatif, mekanisme dan sistem keberlanjutan yang membentuk sebuah rejim transnasional yang kompleks (Pacheco, Schoneveld, Dermawan, Komarudin, \& Djama, 2018). Interaksi aktor dan sistem pengambilan keputusan terkait industri perkebunan sawit, berimplikasi pada hak-hak atas tanah dan perubahan penggunaan lahan (Myers, Sanders, Larson, Prasti, \& Ravikumar, 2016).

Pasar yang berkembang pesat untuk biofuel dan minyak nabati, terutama di Cina, India, Eropa Timur, dan Timur Tengah serta Amerika Serikat telah mendorong masuknya investasi besar di negara-negara produsen di Asia Tenggara, Afrika dan Amerika Latin (Colchester \& Chao, 2011; Colchester, Jiwan, \& Chao, 2013). Investasi skala besar tersebut menyebabkan semakin meningkatnya laju transfer dan pengambilalihan lahan dari pemiliknya, seperti masyarakat lokal dan adat demi kepentingan pengembangan perkebunan kelapa sawit (Colchester et al., 2013; Deininger \& Byerlee, 2011; Li, 2017; Semedi \& Bakker, 2014)

Para petani di sekitar perkebunan skala besar menjadi termotivasi ikut membuka kebun sawit dengan luas yang bervariasi, baik mereka yang awalnya menjadi mitra kontrak dengan perusahaan (Deininger \& Byerlee, 2011; Simmons, Winters, \& Patrick, 2005)maupun petani swadaya dengan dukungan sumber daya dan modal sendiri. Sebagai dampak dari perkembangan tersebut, laju perluasan sawit rakyat tahunan bahkan diduga lebih tinggi dibanding laju perluasan yang dilakukan perusahaan besar (Lee et al., 2014). Secara faktual, bisnis sawit menghasilkan keuntungan besar yang memicu produsen untuk semakin memperluas operasinya (Susanti, 2016; Wicke, Sikkema, Veronika, \& Faaij, 2011). Tidak mengejutkan bila kemudian terjadi proses transformasi penggunaan lahan dan kawasan yang secara bertahap terintegrasi ke dalam pasar global (Beckert, Dittrich, \& Adiwibowo, 2014).

Kontestasi ruang spasial dan lahan untuk perkebunan sawit di masa mendatang tampaknya akan tetap berlangsung, termasuk di Indonesia yang saat ini menjadi negara produsen dan pengekspor minyak sawit terbesar di dunia. Asumsi ini berdasarkan pada rencana pemerintah pada 2015 yang menargetkan peningkatan produksi minyak sawit mentah dua kali dari produksi saat itu menjadi 40 juta ton pada tahun 2020 (Kompas, 2015; Pusat Kebijakan Kerjasama Perdagangan Internasional, 2015), yang membutuhkan tambahan luas 6 juta ha perkebunan kelapa sawit (Gingold, 2010). Terbangunnya industri pengolahan dengan kapasitas yang meningkat serta program hilirisasi industri CPO (Kompas, 2015) akan mendorong kebutuhan untuk memenuhi pasokan bahan baku, yang seringkali tidak selalu dapat dipenuhi dari perkebunan yang ada.

Besarnya peran industri minyak sawit di dalam menopang perekonomian nasional dan semakin meningkatnya kinerja sektor perkebunan ternyata dihadapkan pada berbagai tantangan yang kompleks. Salah satu tantangan tersebut adalah adanya perkebunan kelapa sawit atau lahan untuk perkebunan yang dikuasai perusahaan, perseorangan atau kelompok masyarakat yang berada secara ilegal di atas kawasan hutan. Dari total luas perkebunan kelapa sawit nasional yang mencapai 14,03 juta ha, sekitar 2,5 juta ha atau $21 \%$ nya terindikasi berada di dalam kawasan hutan, yang terdiri dari perkebunan yang 
dikuasai perusahaan swasta/BUMN seluas 800 ribu ha dan perkebunan rakyat 1,7 juta ha (Direktorat Jenderal Perkebunan, 2017). Presiden juga mengindikasikan bahwa di Pulau Kalimantan saja terdapat kurang lebih 4 juta ha kawasan hutan tumpang tindih dengan kawasan perkebunan. ${ }^{1}$ Sementara, dari total luas perkebunan kelapa sawit di Provinsi Riau yang mencapai 4,44 juta ha, sekitar 2,42 juta ha diantaranya adalah dikelola petani, dan dari luas tersebut sekitar 1,3 juta ha atau $56 \%$ nya diklaim berada dalam kawasan hutan. ${ }^{2}$

Aspek legalitas penguasaan (tenurial) lahan merupakan aspek krusial yang menjadi bagian penting tata kelola perkebunan kelapa sawit yang baik. Permasalahan tidak jelasnya legalitas dan tenurial, baik yang dihadapi perusahaan maupun petani berimplikasi pada aspek kepastian berusaha, legalitas dan legitimasi produk-produk perkebunan yang dihasilkan. Selain itu, aspek legalitas lahan menjadi salah satu kendala penting di dalam proses sertifikasi minyak sawit berkelanjutan. Di sisi lain, penguasaan kawasan hutan secara ilegal dan tidak terselesaikannya permasalahan tenurial menyebabkan hilangnya penerimaan negara dan terhambatnya akses bagi investor dan petani untuk meningkatkan produktivitas (Bronkhorst et al., 2017).

\subsection{Tujuan dan metode}

Paper ini bertujuan untuk memahami dengan lebih baik mengapa dan bagaimana penguasaan lahan untuk perkebunan sawit terjadi di dalam kawasan hutan. Mengacu pada kerangka pendekatan yang dikembangkan Hall (2011), tujuan paper penelitian ini adalah untuk menganalisis praktik dan strategi beragam aktor di dalam menguasai dan memperluas lahan perkebunan kelapa sawit, terutama yang masuk ke dalam kawasan hutan. Sementara sebagian besar penelitian sebelumnya lebih fokus pada penguasaan lahan skala besar oleh perusahaan, paper ini sejalan dengan Hall (2011) yang juga melihat peranan signifikan aktor petani atau pekebun dalam menguasai lahan yang akan dijadikan kebun sawit.

Paper ini juga bertujuan untuk menilai implementasi kebijakan pelepasan dan tukar menukar kawasan hutan untuk penggunaan non kehutanan, moratorium perizinan sawit, reforma agraria atau Tanah Obyek Reforma Agraria (TORA) dan perhutanan sosial yang bertujuan untuk menyelesaikan masalah penguasaan lahan ini. Selain itu, paper ini bertujuan mengidentifikasi tantangan-tantangan yang menghambat efektifitas pelaksanaan kebijakan. Pada akhir, paper ini menawarkan beberapa opsi kebijakan dan terobosan dalam upaya mendorong penyelesaian masalah tenurial perkebunan sawit berdasarkan bukti dan fakta yang ditemukan di lapangan.

Paper ini disusun berdasarkan penelitian yang dilakukan sepanjang tahun 2017 dengan mengambil studi kasus di Kalimantan Tengah dan Kalimantan Barat, yang keduanya merupakan penghasil utama minyak sawit. Penelitian ini menggunakan metode wawancara mendalam (indepth interview), dengan melibatkan 40 responden dan wawancara semi terstruktur (semi structured) dengan melibatkan 86 responden, yang terkait dengan isu-isu tenurial, lahan, sektor kehutanan dan perkebunan kelapa sawit. Beberapa seri diskusi kelompok terfokus dan satu lokakarya dilakukan dengan melibatkan peserta yang mewakili beragam kelompok untuk memahami lebih dalam pandangan berbagai pihak terhadap permasalahan tenurial perkebunan kelapa sawit dan kawasan hutan, dan opsi-opsi penyelesaiannya. Dalam diskusi kelompok terfokus juga digali persoalan-persoalan yang terkait soal lahan dan perizinan, yang menjadi bagian penting dari tata kelola pengembangan perkebunan kelapa sawit. Setiawan, Maryudi, Purwanto, \& Lele (2016) menyatakan bahwa kompleksitas tenurial perkebunan kelapa sawit bukan hanya terkait dengan hal-hal teknis administrasi alokasi dan penggunaan lahan hutan dan rezim perizinan saja, tetapi juga dengan masalah tata kelola pengembangan perkebunan kelapa sawit.

1 Disampaikan Presiden Jokowi pada saat membuka rapat terbatas tentang kebijakan satu peta di Kantor Presiden, Kompleks Istana Kepresidenan, Jakarta, Senin (5/2/2018). http://nasional.kompas.com/read/2018/02/05/16191641/jokowi-dikalimantan-4-juta-hektar-hutan-tumpang-tindih-dengan-perkebunan

2 Hasil penelitian Tim IT APKASINDO Riau (https://perkebunannews.com/2017/04/15/56-persen-perkebunan-sawitrakyat-di-riau-ada-di-kawasan-hutan/) 
Observasi lapangan di beberapa kabupaten terpilih di kedua provinsi juga dilakukan untuk memahami lebih dalam konteks yang diteliti melalui pengamatan praktik-praktik penguasaan lahan dan kondisi perkebunan kelapa sawit yang berada di kawasan hutan. Untuk melengkapi hasil wawancara dan diskusi kelompok terfokus, kami juga melakukan analisis data sekunder dan berbagai dokumen kebijakan terkait tata kelola perkebunan kelapa sawit berkelanjutan, yang dikeluarkan oleh pemerintah pusat dan pemerintah daerah maupun perusahaan. Analisis dilakukan untuk melihat berbagai pandangan para pihak dan sejauh mana efektivitas instrumen dan pendekatan kebijakan di dalam menyelesaikan permasalahan tenurial perkebunan kelapa sawit di kawasan hutan.

Sebaran perkebunan kelapa sawit yang berada di dalam kawasan hutan diketahui dengan menggunakan metode analisis data spasial yang mencakup data overlay, attribute data processing, penggabungan dan pemisahan data spasial terhadap berbagai peta tematik seperti peta kawasan hutan, peta indikatif alokasi kawasan hutan untuk penyediaan sumber Tanah Objek Reforma Agraria (TORA), peta rupa bumi, digital elevation model (DEM) dari citra Shuttle Radar Topography Mission (SRTM) dan peta perkebunan kelapa sawit hasil interpretasi citra satelit. Pada tahap akhir, dilakukan penghitungan luas area hasil analisis data spasial dan pembuatan layout peta hasil analisis. 


\section{Perkebunan kelapa sawit dan kawasan hutan}

Minyak sawit merupakan komoditas strategis yang menjadi sumber penghasil devisa negara, penyediaan lapangan kerja dan peningkatan kesejahteraan masyarakat. Kinerja komoditas perkebunan kelapa sawit pada tahun 2017 ditunjukan dengan pencapaian luas perkebunan yang saat ini tercatat 14,03 juta ha dan produksi 37,8 juta ton. Dari luasan tersebut, perkebunan yang dikelola oleh perusahaan besar swasta mencapai 7,7 juta ha (54,9\%), BUMN 710,000 ha (5\%) dan rakyat 5,6 juta ha (40\%) (Direktorat Jenderal Perkebunan, 2018a). Gambar 1 menyajikan sebaran, luas dan produksi perkebunan kelapa sawit di berbagai provinsi.

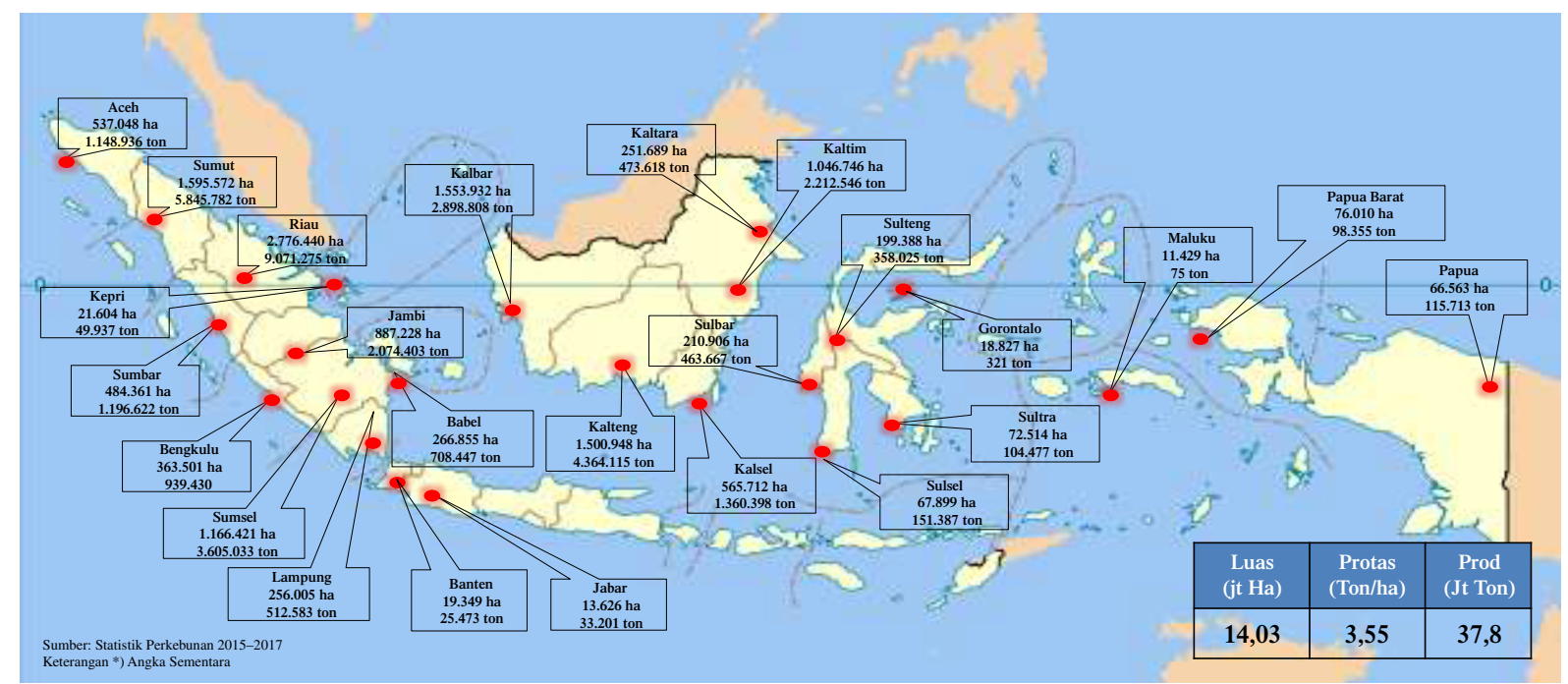

Gambar 1. Sebaran, luas dan produksi perkebunan kelapa sawit di berbagai provinsi

Sumber: (Direktorat Jenderal Perkebunan, 2018b)

\subsection{Sejarah perkembangan investasi kehutanan dan perkebunan: Titik berat pada aspek politik dan ekonomi}

Tinjauan sejarah investasi di sektor kehutanan dan perkebunan sangat berguna dalam memahami perkembangan dan sebaran perkebunan kelapa sawit, yang sebagian keberadaanya pada akhirnya diketahui berada di dalam kawasan hutan. Titik awal perjalanan investasi sumberdaya hutan adalah ketika sekitar tahun 1970an, pemerintah memberikan izin konsesi pemanfaatan hutan di luar Jawa kepada sejumlah badan usaha Hak Pengusahaan Hutan (HPH). Pemerintah dalam hal ini Menteri Pertanian yang bertugas menangani urusan kehutanan mengeluarkan Keputusan Menteri Pertanian No. 291/Kpts/Um/1970 tentang Penetapan Areal Kerja Pengusahaan Hutan sebagai Hutan Produksi (Djajapertjunda dan Djamhuri 2013). Pada saat itu, kepentingan politik dan ekonomi merupakan satusatunya pertimbangan utama dalam mengelola hutan dengan tujuan untuk mendapatkan hasil hutan kayu dan hasil hutan bukan kayu.

Untuk menghindari tumpang tindih antara kawasan hutan produksi dengan kawasan yang direncanakan oleh sektor lain, Direktorat Jenderal Kehutanan pada tahun 1981 mengambil inisiatif membuat peta 
kesepakatan sementara antara instansi terkait seperti Departemen Pertanian, Departemen Pekerjaan Umum dan Departemen Dalam Negeri. Peta tersebut berkaitan dengan penetapan batas-batas hutan yang direncanakan sebagai kawasan hutan sesuai fungsinya, dan juga hutan yang dapat dikonversi untuk kepentingan sektor perkebunan dan transmigrasi. Pertimbangan dalam penetapan batas-batas tersebut juga lebih berdasarkan pada kepentingan untuk memenuhi sasaran kebijakan ekonomi politik, baik sektor transmigrasi, pertambangan, pembangunan infrastruktur atau lainnya. Kesepakatan yang kemudian dikenal dengan Tata Guna Hutan Kesepakatan (TGHK) terjadi pada 1984, yang terwujud dalam luasan kawasan hutan yang terbagi ke dalam beberapa fungsi hutan. Setelah peta melewati beberapa penyempurnaan, dihasilkan sebaran luasan hutan berdasarkan fungsinya seperti disajikan pada Tabel 1.

Tabel 1. Kawasan hutan menurut TGHK (1984)

\begin{tabular}{llc}
\hline No & Fungsi hutan & \multicolumn{1}{l}{ Luas (ha) } \\
\hline 1 & Hutan Lindung (HL) & 30.316 .100 \\
2 & Hutan Konservasi (HK) & 18.725 .215 \\
3 & Hutan Produksi Terbatas (HPT) & 30.525 .300 \\
4 & Hutan Produksi (HP) & 33.866 .600 \\
5 & Hutan Produksi Konversi (HPK) & 19.000 .000 \\
Total & & 132.433 .215 \\
\hline
\end{tabular}

Sumber: Djajapertjunda dan Djamhuri (2013)

Peta TGHK digunakan sebagai bahan pertimbangan dalam pengambilan keputusan tentang perubahan status hutan menjadi kawasan non-hutan, yang diakomodasi dalam kawasan hutan dengan fungsi hutan produksi yang dapat dikonversi (HPK). Pelepasan kawasan hutan untuk keperluan lain, termasuk untuk perkebunan, diatur pertama kali pada 1980 melalui Keputusan Menteri Pertanian No. 764/Kpts/Um/10/1980 yang saat itu juga mempertimbangkan pentingnya pembangunan, kemajuan ekonomi dengan tetap menjaga kelestarian lingkungan. Pembangunan perkebunan kelapa sawit yang berperan dalam membuka wilayah yang terisolasi dan membuka lapangan pekerjaan dilakukan dengan memadukan antara perkebunan utama yang disebut dengan inti, yang dikelilingi secara terintegrasi dengan perkebunan pendukung yang disebut plasma, melalui Perkebunan Inti Rakyat (PIR) yang mulai diperkenalkan pada tahun 1977. Melalui Instruksi Presiden No. 1/1986, pembangunan perkebunan dipadukan dengan program transmigrasi, yang dikenal dengan nama PIR-TRANS.

Meningkatnya investasi di sektor perkebunan kelapa sawit yang diiringi oleh semakin luasnya areal perkebunan tidak terlepas dari peranan kebijakan pemerintah dalam mendorong perluasan. Keputusan Menteri Kehutanan dan Perkebunan No. 107/1999, misalnya, mengatur peningkatan batas luasan Izin Usaha Perkebunan dari hanya 200 ha menjadi 1000 ha. Batasan luas lahan usaha budidaya perkebunan tersebut kemudian diubah melalui Keputusan Menteri Pertanian No. 357/2002 menjadi maksimum 20.000 ha dalam satu provinsi atau 100.000 ha untuk seluruh Indonesia bagi satu perusahaan atau group perusahaan, yang disertai kewajiban membangun kerjasama kemitraan dengan perusahaan skala kecil dan menengah yang dinamakan PIR- Kredit Koperasi Primer untuk Anggotanya (PIR-KKPA). Batasan paling luas sampai 100.000 ha untuk setiap perusahaan kembali dipertegas melalui Peraturan Menteri Pertanian No. 26/2017. Peraturan ini menimbulkan kontroversi dan banyak menerima sorotan publik, karena luasnya lahan yang dapat dikuasai sebuah perusahaan, dianggap berpotensi hanya dijadikan sekedar cadangan lahan atau land bank, tidak untuk diusahakan bagi perkembangan perkebunan secara serius. Dalam kurun waktu 20 tahun antara 1990 sampai 2010, perkebunan kelapa sawit berkembang dari sekitar 1,1 juta ha menjadi 7,8 juta ha, dan menjadi 14,03 juta ha saat ini.

Dalam tiga tahun antara 2010 sampai 2013, areal yang dialokasikan untuk perkebunan sawit meningkat sebesar 35\%, dari 7,8 juta ha menjadi 10 juta ha atau setara dengan peningkatan sebesar 
520.000 ha per tahun (Djajapertjunda dan Djamhuri 2013). Peningkatan tersebut juga seiring dengan diberlakukannya kebijakan otonomi daerah yang memberi kewenangan lebih besar kepada pemerintah daerah untuk mengeluarkan izin prinsip dan izin lokasi untuk usaha perkebunan sawit. Pemberian izin bagi investor yang tidak terkendali dan tidak memperhatikan tahapan-tahapan prosedur menjadi salah satu penyebab mengapa kemudian banyak perkebunan kelapa sawit yang diketahui berada dalam kawasan hutan. Sebagian investor membuka lahan dan menanam kelapa sawit hanya dengan berbekal izin prinsip atau izin lokasi saja, padahal izin pelepasan dari Kementerian Lingkungan Hidup dan Kehutanan masih dalam tahap penyelesaian atau bahkan belum dimiliki.

Lonjakan luasan perkebunan kelapa sawit seperti yang ada sekarang ini ternyata tidak terlepas dari insentif yang diberikan pemerintah. Bahkan sejak 1996, Presiden Soeharto ternyata sudah mencanangkan Indonesia menjadi produsen dan eksportir terbesar di dunia mengalahkan Malaysia dengan cara meningkatkan luas perkebunan kelapa sawit menjadi dua kali lipat, atau 5,5 juta ha pada tahun 2000, yang tersebar di Sumatera, Kalimantan, Sulawesi dan Irian Jaya (Papua). Setengah dari luas perkebunan tersebut dialokasikan bagi perusahaan-perusahaan swasta asing.

\subsection{Perkebunan kelapa sawit yang berasal dari pelepasan kawasan hutan}

Melalui prosedur legal, angka luasan kawasan hutan yang telah berubah menjadi areal perkebunan kelapa sawit semakin meningkat. Dari luas perkebunan kelapa sawit yang saat ini mencapai 14,03 juta ha (Direktorat Jenderal Perkebunan, 2018a), sekitar 5.418.413 ha berasal dari kawasan hutan melalui proses pelepasan, yang diberikan kepada 518 unit perusahaan (Direktorat Pengukuhan dan Penatagunaan Kawasan Hutan, 2018a). Ini berarti luasan perkebunan kelapa sawit yang berasal dari kawasan hutan mencapai 38,6\%. Provinsi Kalimantan Tengah menempati ranking kedua setelah Riau di dalam hal luasan (Gambar 2).

Daya tarik komoditas kelapa sawit seiring dengan meningkatnya harga minyak di pasar global memberi peluang semakin besarnya tekanan terhadap hutan, yang mengakibatkan berkurangnya kawasan hutan. Pengurangan hutan terjadi, baik melalui proses legal pelepasan kawasan hutan untuk

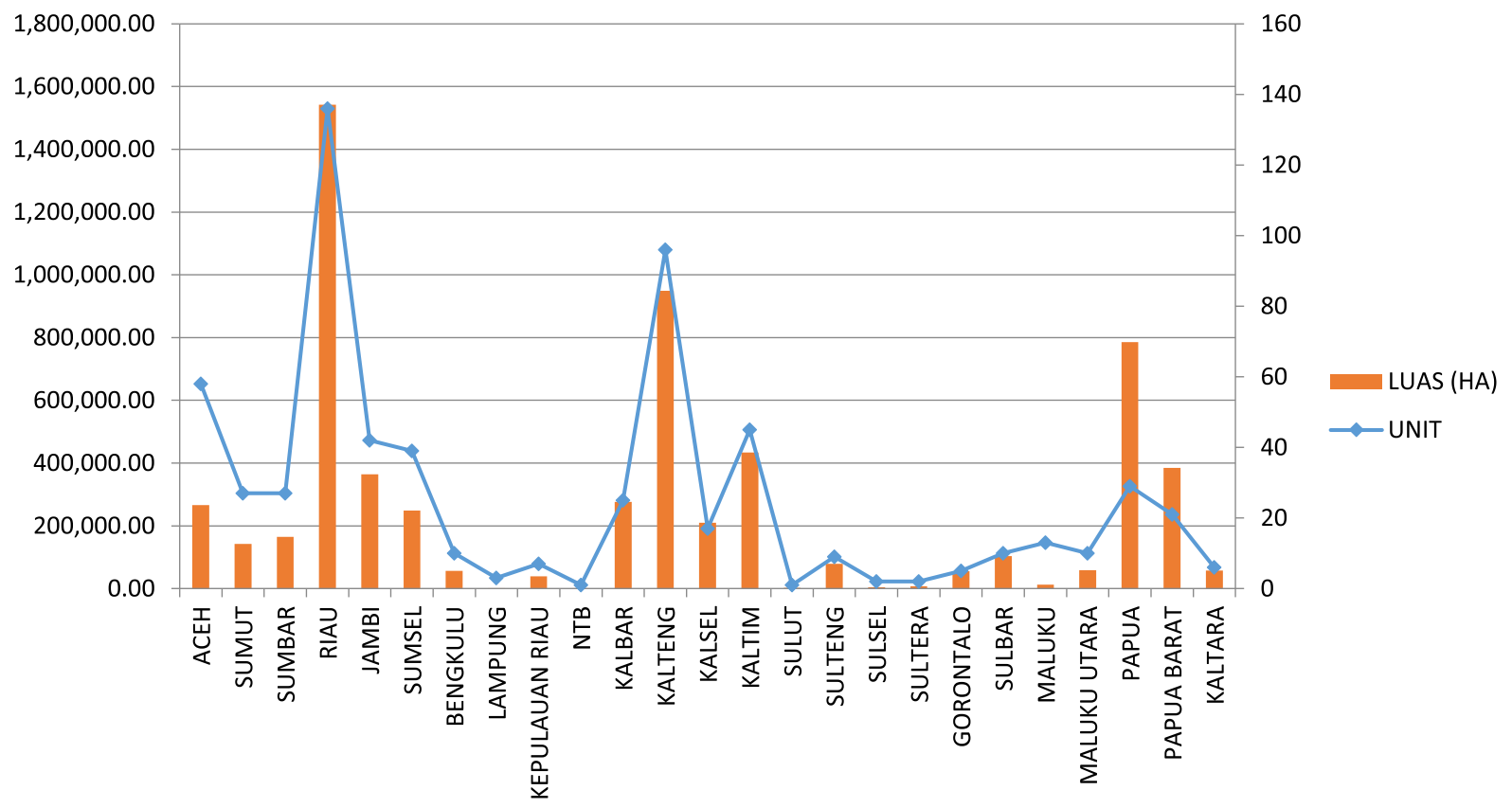

Gambar 2. Luas kawasan hutan yang dilepaskan untuk perkebunan berdasarkan provinsi (Oktober 2018) 
perkebunan, maupun akibat perkebunan-perkebunan kelapa sawit ilegal yang diketahui berada di dalam kawasan hutan. Konflik Perluasan perkebunan kelapa sawit ilegal tersebut telah memicu terjadinya beragam konflik, yang melibatkan antar pihak seperti masyarakat dengan perusahaan, dan masyarakat dengan pemerintah. Selain konflik, tumpang tindih antar penggunaan dan pemanfaatan lahan juga seringkali terjadi.

Proses pelepasan kawasan hutan untuk kepentingan di luar kehutanan tampaknya akan tetap berlanjut di masa-masa mendatang. Berdasarkan Rencana Kehutanan Tingkat Nasional (RKTN) tahun 2011-2030 (Kementerian Kehutanan RI, 2011), hasil analisis spasial dan rasionalisasi kawasan hutan menunjukkan bahwa sampai dengan tahun 2030, total seluas 18 juta ha kawasan hutan dapat dialokasikan untuk kepentingan pembangunan sektor non kehutanan. Alokasi kawasan hutan tersebut dimaksudkan untuk memenuhi tuntutan dinamika pembangunan nasional dan kebutuhan masyarakat dengan tetap mempertimbangkan optimalisasi distribusi fungsi dan manfaat kawasan hutan, dan menaati peraturan perundangan yang berlaku. 


\section{Praktik dan strategi pengadaan dan penguasaan lahan untuk perkebunan sawit}

\subsection{Proses investasi dan perizinan perkebunan kelapa sawit}

Praktik pengadaan, penguasaan dan perluasan lahan untuk perkebunan kelapa sawit setidaknya berlangsung melalui lima ranah. Pertama, pengadaan lahan untuk perkebunan dilakukan melalui proses tata ruang dan perubahannya, yang di dalamnya termasuk proses pelepasan kawasan hutan dengan perizinan dari Kementerian Lingkungan Hidup dan Kehutanan. Kedua, melalui jalur regulasi dan mekanisme perizinan. Ketiga, lahan-lahan untuk perkebunan dikuasai melalui jalur masyarakat, terutama dengan memanfaatkan sistem patronase dengan elit lokal. Keempat, penguasaan lahan dilakukan melalui skema kemitraan dengan masyarakat lokal yang memang menjadi kewajiban investor dalam mengembangkan usahanya. Melalui skema kemitraan, investor memperluas perkebunan dengan memfasilitasi pembangunan kebun untuk masyarakat, yang berada di luar Izin Usaha Perkebunan mereka. ${ }^{3}$ Praktik tersebut diduga dimanfaatkan untuk pengadaan lahan dengan harga murah (Kompas, 2016). Kelima, melalui jalur politik, terutama lobi-lobi politik dan bisnis.

Seperti disajikan pada Gambar 3, tahapan pertama bagi investor adalah mengajukan izin lokasi kepada pemerintah daerah setempat. Berdasarkan pengalaman investor, lamanya pengurusan izin lokasi paling lambat 3 tahun, dan keterlambatan proses umumnya disebabkan proses pelepasan lahannya yang bermasalah. Dengan berbekal izin lokasi, investor mulai melakukan pembebasan lahan dan menyelesaikan hak-hak atas tanah, termasuk dengan masyarakat. Izin lokasi berlaku hanya 3 tahun dan dapat diperpanjang 1 tahun. Investor dapat memperoleh IUP dengan syarat $50 \%$ plus $1 \%$ lahannya sudah harus clear and clean.

Setelah izin lokasi diperoleh, investor melakukan proses analisis dampak lingkungan (AMDAL) dan mengajukan izin lingkungan. Secara paralel berlangsung proses penataan batas dan persetujuan pelepasan kawasan hutan, terutama yang lokasi perkebunannya berasal dari kawasan hutan dengan fungsi HPK.

Dengan kelengkapan izin AMDAL, izin lingkungan dan izin pelepasan kawasan hutan, investor mengajukan Izin Usaha Perkebunan (IUP). Tidak semua perusahaan yang sudah memegang izin lokasi akan memperoleh IUP dengan luasan yang sama yang tertera dalam izin lokasi. Dari luasan 20 ribu ha, misalnya, maka bila ada lahan-lahan yang peruntukannya tidak sesuai dengan tata ruang akan dikeluarkan dari luasan yang diajukan dalam izin lokasi.

Dengan memiliki IUP, investor sudah boleh melakukan kegiatan persiapan usaha perkebunan termasuk pembukaan lahan, persemaian dan membangun fasilitas. Pada lahan-lahan dengan potensi tegakan pohon, maka investor harus mengajukan Izin Pemanfaatan Kayu (IPK) kepada instansi kehutanan setempat sebelum pembukaan lahan dan pohon-pohon kayu ditebang dan diangkut.

Setelah memperoleh IUP, investor harus mengajukan Hak Guna Usaha (HGU) kepada Badan Pertanahan Nasional, dengan persyaratan izin pelepasan kawasan. Balai Pemantapan Kawasan Hutan (BPKH) berperan untuk menelaah lahan yang dimohonkan dan hasil telahaannya kemudian menjadi bahan pertimbangan teknis bagi Badan Pertanahan Nasional untuk mengeluarkan HGU.

3 Pasal 15 Peraturan Menteri No. 98/Permentan/Ot.140/9/2013 tentang Pedoman Perizinan Usaha Perkebunan. 


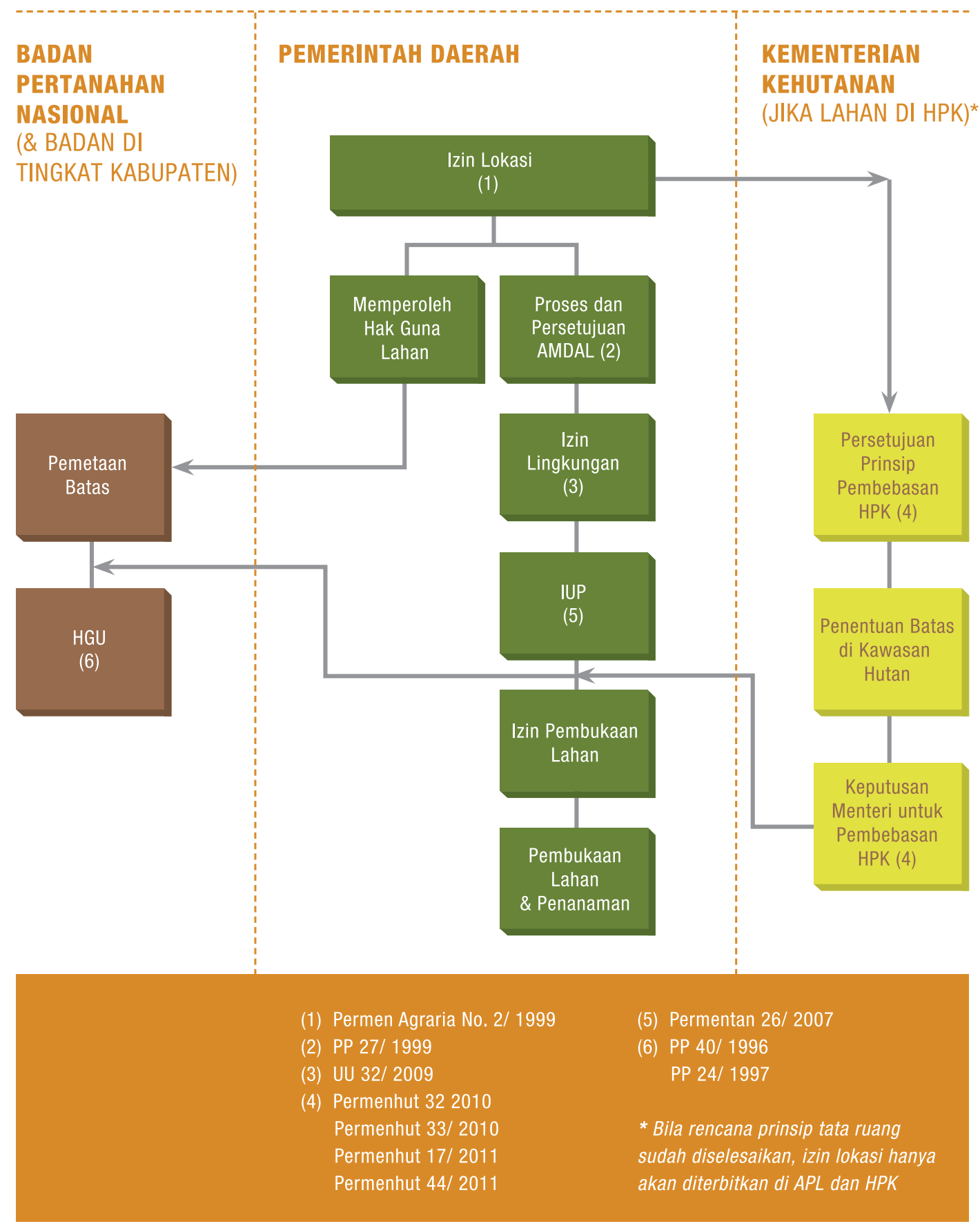

Gambar 3. Diagram alir proses perolehan perizinan perkebunan dan persetujuan usaha perkebunan kelapa sawit

Sumber: (Paoli et al., 2013)

Dalam proses investasi perkebunan sawit, tidak semua perusahaan mengikuti proses dari proses awal atau dari mendapatkan izin prinsip atau pun lokasi. Tidak sedikit perusahaan yang tidak mau melalui tahap-tahap mekanisme perizinan yang dipandang sangat rumit. Sebagian perusahan, misalnya dari Malaysia, cenderung menempuh langkah dengan membeli izin lokasi dari perusahaan lain. Seringkali, cara-cara yang tidak melalui tahapan interaksi dengan masyarakat tersebut berujung konflik dengan masyarakat ketika perusahaan bersangkutan sudah mulai beroperasi. Di beberapa kasus diketahui, janji-janji yang disampaikan kepada masyarakat dan belum dipenuhi oleh perusahaan sebelumnya, menjadi pemicu konflik karena perusahaan yang baru merasa tidak berkewajiban untuk memenuhinya. 


\subsection{Perkebunan kelapa sawit terindikasi dalam kawasan hutan}

Dari luas total perkebunan kelapa sawit nasional yang mencapai 14,03 juta ha (Direktorat Jenderal Perkebunan, 2018a), sekitar 2,5 juta ha atau $21 \%$ dari luas total perkebunan terindikasi berada di dalam kawasan hutan, yang terdiri dari perkebunan yang dikuasai perusahaan swasta/BUMN seluas 800 ribu ha dan perkebunan rakyat 1,7 juta ha (Direktorat Jenderal Perkebunan, 2017). Perkebunan tersebut tidak hanya berada di dalam areal yang berstatus fungsi hutan produksi yang dapat dikonversi (tanpa terlebih dahulu melalui proses pelepasan kawasan), tetapi juga masuk ke kawasan hutan produksi, hutan lindung dan bahkan hutan konservasi.

Direktorat Penelitian dan Pengembangan Kedeputian Bidang Pencegahan KPK RI (2016) menemukan bahwa banyak izin perkebunan kelapa sawit, baik IUP maupun HGU, yang tidak sesuai dengan peruntukan lahan dan tumpang tindih. Sekitar 880.000 ha HGU perkebunan kelapa sawit berada di dalam kawasan hutan, yang sudah diperuntukkan bagi izin usaha IUPHHK hutan tanaman (534.512 ha) dan IUPHHK hutan alam (349.664 ha). Sumber lain menunjukkan bahwa luas perkebunan kelapa sawit di dalam kawasan hutan melebihi data yang dikeluarkan dan Dirjen Perkebunan, yakni mencapai 3,5 juta ha dan bahkan lebih luas. Auriga (2018) menyatakan bahwa dari sekitar total luas perkebunan kelapa sawit yang mencapai 16.829 .282 ha, sekitar 20,6\% nya berada di dalam kawasan hutan yang tersebar di berbagai provinsi di Indonesia (Tabel 2). Riau dan Kalimantan Tengah adalah dua provinsi dengan areal perkebunan kelapa sawit terluas yang terindikasi berada di dalam kawasan hutan.

Dalam rapat terbatas tentang kebijakan satu peta, Presiden Jokowi ${ }^{4}$ menyatakan bahwa di Pulau Kalimantan terdapat kurang lebih 4 juta ha kawasan hutan yang tumpang tindih dengan kawasan perkebunan. Pernyataan tersebut setidaknya mengkonfirmasi perkiraan luasnya tumpang tindih di provinsi-provinsi di Kalimantan seperti tertuang pada Tabel 2. Di Provinsi Riau, luas perkebunan kelapa sawit mencapai 4.44 juta ha, dan sekitar 2,42 juta ha diantaranya adalah kebun rakyat. Dari luas kebun rakyat tersebut, sekitar 1,3 juta ha atau 54\% nya ditengarai berada di dalam kawasan hutan. Luas perkebunan rakyat yang diduga berada dalam kawasan hutan ini jauh melebihi luas perkebunan perusahaan yang diperkirakan berada dalam kawasan hutan, seperti disajikan pada Tabel $2 .{ }^{5}$

Data dari Komisi Kehutanan DPR menunjukkan bahwa sekitar 1,5 juta ha lahan milik perusahaan perkebunan kelapa sawit di Provinsi Kalimantan Tengah terindikasi ilegal karena menggunakan kawasan hutan (Tempo, 2016). Panitia Kerja Pengalihan Lahan Kehutanan yang dibentuk untuk menyelesaikan kasus tumpang tindih lahan tersebut mengkonfirmasi adanya lahan seluas 40 ribu ha yang dikuasai oleh tiga perusahan, yang berdasarkan penafsiran citra satelit terbukti jelas-jelas masuk ke dalam kawasan hutan produksi.

Terdapat beragam data total luasan perkebunan kelapa sawit dan luasan perkebunan kepala sawit di dalam kawasan hutan yang dikeluarkan oleh lembaga yang berbeda, baik pemerintah maupun non pemerintah. Saat ini pemerintah tengah menginisiasi proses rekonsiliasi data dalam rangka menghasilkan data resmi dan tunggal. Terlepas dari itu, angka-angka luasan tersebut perlu divalidasi keakuratannya dan isu keberadaan perkebunan kelapa sawit di dalam kawasan hutan perlu mendapatkan perhatian dan dicari solusi kebijakannya dengan mendasarkan pada fakta dan bukti lapangan yang kuat.

\footnotetext{
4 "Seperti informasi yang saya terima di Pulau Kalimantan, terdapat lebih kurang 4 juta hektare kawasan hutan tumpang tindih dengan kawasan perkebunan," kata Jokowi saat membuka rapat terbatas tentang kebijakan satu peta, di Kantor Presiden, Kompleks Istana Kepresidenan, Jakarta, Senin (5/2/2018). http://nasional.kompas.com/read/2018/02/05/16191641/ jokowi-di-kalimantan-4-juta-hektar-hutan-tumpang-tindih-dengan-perkebunan

5 https://perkebunannews.com/2017/04/15/56-persen-perkebunan-sawit-rakyat-di-riau-ada-di-kawasan-hutan/
} 
Tabel 2. Jumlah unit dan luas perkebunan termasuk perkebunan kelapa sawit dalam kawasan hutan

\begin{tabular}{|c|c|c|c|c|c|c|c|c|c|}
\hline \multirow[t]{2}{*}{ Kode } & \multirow[t]{2}{*}{ Provinsi } & \multicolumn{8}{|c|}{ Luas areal (ha) } \\
\hline & & Total & $\begin{array}{l}\text { Areal } \\
\text { Penggunaan } \\
\text { Lain (APL) }\end{array}$ & $\begin{array}{l}\text { Kawasan Suaka Alam/ } \\
\text { Kawasan Pelestarian } \\
\text { Alam (KSA/KPA) }\end{array}$ & $\begin{array}{l}\text { Hutan } \\
\text { Lindung } \\
\text { (HL) }\end{array}$ & $\begin{array}{l}\text { Hutan } \\
\text { Produksi } \\
\text { Terbatas (HPT) } \\
\end{array}$ & $\begin{array}{l}\text { Hutan } \\
\text { Produksi } \\
\text { (HP) }\end{array}$ & $\begin{array}{l}\text { Hutan Produksi } \\
\text { Konversi (HPK) }\end{array}$ & $\begin{array}{l}\text { Total Perkebunan } \\
\text { Kelapa Sawit di dalam } \\
\text { Kawasan Hutan }\end{array}$ \\
\hline 11 & Aceh & 974,860 & 925,510 & 6,060 & 12,879 & 2,599 & 22,646 & 5,166 & 49,350 \\
\hline 12 & Sumatera Utara & $2,254,488$ & $1,923,775$ & 8,462 & 21,752 & 49,863 & 202,300 & 48,336 & 330,714 \\
\hline 13 & Sumatera Barat & 552,066 & 492,902 & 1,399 & 11,278 & 4,127 & 17,284 & 25,076 & 59,164 \\
\hline 14 & Riau & $3,251,477$ & $2,020,007$ & 34,619 & 54,352 & 250,115 & 353,361 & 539,023 & $1,231,470$ \\
\hline 15 & Jambi & 949,667 & 854,358 & 2,562 & 5,085 & 10,647 & 69,089 & 7,926 & 95,309 \\
\hline 16 & Sumatera Selatan & $1,354,053$ & $1,135,627$ & 16,458 & 3,066 & 24,099 & 121,905 & 52,898 & 218,425 \\
\hline 17 & Bengkulu & 516,939 & 474,229 & 3,225 & 4,073 & 22,062 & 3,996 & 9,354 & 42,709 \\
\hline 18 & Lampung & 347,772 & 321,986 & 415 & 1,459 & 1,637 & 22,275 & & 25,786 \\
\hline 19 & Kep. Bangka Belitung & 311,120 & 259,682 & 1,247 & 8,621 & & 41,570 & & 51,439 \\
\hline 32 & Jawa Barat & 15,485 & 15,222 & 85 & & 104 & 74 & & 263 \\
\hline 36 & Banten & 18,869 & 17,218 & & 181 & 450 & 1,020 & & 1,650 \\
\hline 61 & Kalimantan Barat & $1,830,018$ & $1,715,286$ & 1,299 & 7,076 & 13,041 & 69,895 & 23,421 & 114,731 \\
\hline 62 & Kalimantan Tengah & $1,837,708$ & 853,164 & 11,638 & 31,664 & 62,627 & 401,459 & 477,156 & 984,544 \\
\hline 63 & Kalimantan Selatan & 476,541 & 403,352 & 5,006 & 914 & 511 & 39,049 & 27,709 & 73,190 \\
\hline 64 & Kalimantan Timur & $1,298,196$ & $1,190,409$ & 20,982 & 5,130 & 1,199 & 73,754 & 6,722 & 107,788 \\
\hline 65 & Kalimantan Utara & 300,186 & 272,274 & & 643 & 593 & 26,246 & 430 & 27,911 \\
\hline 72 & Sulawesi Tengah & 113,796 & 105,896 & 1,071 & 634 & 184 & 1,811 & 4,200 & 7,899 \\
\hline 73 & Sulawesi Selatan & 49,104 & 39,538 & 36 & 3,856 & 4,682 & 764 & 228 & 9,565 \\
\hline 74 & Sulawesi Tenggara & 60,133 & 39,318 & 156 & 167 & 786 & 12,498 & 7,208 & 20,814 \\
\hline 75 & Gorontalo & 12,079 & 8,134 & 974 & 413 & 1,550 & 744 & 264 & 3,945 \\
\hline 76 & Sulawesi Barat & 128,767 & 122,595 & & 1,634 & 1,557 & 925 & 2,056 & 6,172 \\
\hline 81 & Maluku & 12,949 & 11,048 & & & & & 1,901 & 1,901 \\
\hline 82 & Maluku Utara & 4,190 & 4,077 & & & & 24 & 89 & 113 \\
\hline 91 & Papua Barat & 50,589 & 43,104 & & & 1,694 & 518 & 5,273 & 7,485 \\
\hline \multirow[t]{2}{*}{94} & Papua & 108,232 & 106,122 & & 32 & 723 & 870 & 485 & 2,111 \\
\hline & Indonesia & $16,829,284$ & $13,354,833$ & 115,694 & 174,909 & 454,850 & $1,484,077$ & $1,244,921$ & $3,474,448$ \\
\hline
\end{tabular}




\subsection{Mengapa perkebunan kelapa sawit di kawasan hutan terjadi?}

Terjadinya kasus-kasus perkebunan kelapa sawit perusahan dalam kawasan hutan dan beroperasinya perusahaan atau perkebunan rakyat tidak bisa dilihat secara hitam putih dan hanya semata karena disebabkan oleh pelanggaran ketentuan peraturan perundang-undangan oleh pelaku usaha atau pekebun sawit. Adalah penting untuk merunut dari sejarah kawasan hutan dan faktor-faktor pengaruh lainnya. Beberapa faktor yang menjadi penyebab adalah: Pertama, berubah-ubahnya kebijakan nasional dan daerah terkait dengan peruntukan tata ruang dan kawasan hutan telah menciptakan berbagai penafsiran dan keputusan alokasi lahan-lahan untuk kebun, yang pada akhirnya menciptakan konflik ruang dalam kawasan hutan. Kasus tersebut sangat jelas terlihat dari apa yang terjadi di Provinsi Kalimantan Tengah. Kedua, tumpang tindih terjadi karena batas fisik kawasan hutan yang tidak jelas, mengingat saat ini belum $100 \%$ kawasan hutan dikukuhkan. ${ }^{6}$ Setelah izin pelepasan kawasan hutan diberikan, umumnya pemohon tidak serta merta melakukan tata batas ulang, sehingga kondisi tersebut memberi peluang terjadinya kesalahan di dalam proses penetapan batas antara kawasan hutan dengan areal penggunaan lain. Pemetaan batas yang hanya di atas kertas dan tidak disertai dengan pengecekan lapangan, yang menjadi fenomena umum di sekitar tahun 2009 dan 2010, memungkinkan kesalahan tersebut terjadi.

Ketiga, belum adanya batas-batas yang jelas antara kawasan hutan dengan wilayah desa dan belum jelasnya tata ruang dan tata guna lahan desa sering mengakibatkan terjadi tumpang tindih antara perkebunan dengan lahan-lahan yang diklaim oleh desa atau pun warga desa sebagai lahan pertanian atau perladangan mereka. Contoh kasus dapat ditemukan di Desa Dabong, Kabupaten Kubu Raya, Kalimantan Barat.

Keempat, pada saat pembukaan lahan, karena ketidakjelasan peta, oknum perusahaan perkebunan atau kontraktor yang disewa menempatkan patok batas di lapangan yang tidak sesuai dengan koordinat yang tertuang di dalam peta. Pergeseran patok batas di lapangan yang hanya $50 \mathrm{~m}$ saja berakibat sangat besar jika panjangnya mencapai $10 \mathrm{~km}$. Ketika lokasi perkebunan berdekatan dengan kawasan hutan, maka pergeseran batas berpotensi mengakibatkan tumpang tindih.

Kelima, praktik yang juga diduga terjadi adalah modus dengan memanfaatkan oknum masyarakat untuk membuka hutan dalam rangka memenuhi kewajiban perusahaan memfasilitasi pembangunan kebun masyarakat seluas 20\% dari luas IUP mereka. Masyarakat dibujuk untuk membuka lahan di sekitar perkebunan perusahaan, dengan iming-iming bahwa perusahaan yang menutup biaya yang dibutuhkan untuk proses administrasinya, termasuk melengkapi surat-surat. Secara de facto, perusahaan mengendalikan lahan tersebut, tetapi secara de jure, mereka tidak mempunyai dasar hukum untuk menguasainya. Praktik ini terjadi bukan hanya karena dorongan dari pihak perusahaan, tetapi juga karena sistem sosial masyarakat yang cenderung mulai rapuh.

Kelima, menurut salah satu narasumber yang mendalami ekonomi politik sawit, modus perusahaan dalam memperluas perkebunan sawitnya adalah dengan terlebih dahulu membentuk koperasi dengan pengurus dari unsur-unsur masyarakat yang cenderung mendukung pembukaan investasi. Melalui koperasi tersebut, perusahaan melalui staf perusahaan atau operator melakukan intervensi dengan mempengaruhi pengurus koperasi atau aktor-aktor lain yang terkait agar membuka lahan-bahkan pada beberapa kasus dengan cara membakar-dan menanaminya dengan sawit. Narasumber lain menyatakan bahwa praktik-praktik yang tidak sesuai prosedur seringkali dilakukan oleh perusahaan karena mereka tahu aparatnya lemah. Tidak jelasnya batas kawasan di lapangan dan dorongan untuk memperluas kebun tanpa mengikuti prosedur, kasus-kasus yang terjadi seperti digambarkan pada

6 (Data 2014 baru mencapai $62 \%$ ).

7 Menurut responden yang berpengalaman bekerja di perkebunan, sekitar tahun 2009-2010, pemetataan batas sering di atas kertas. Cek lapangan jarang dilakukan karena biayanya mahal dan lokasinya berat. 
faktor keempat dan kelima sering berujung lahan-lahan yang dibuka dan kebun-kebun yang dibangun berada dalam kawasan hutan.

Kasus di Buayan, Kecamatan Meliau, Kabupaten Sanggau menunjukkan dua pendekatan yang dilakukan perusahaan dalam memperoleh lahan-lahan untuk perkebunan: pendekatan lunak dan keras. Dalam pendekatan pertama, perusahaan memanfaatkan fasilitas dari pemerintah setempat dan elit-elit lokal. Semedi \& Bakker (2014) dan Li (2017) menggambarkan bahwa untuk memenuhi kebutuhan lahan, perusahaan membangun kerjasama dengan pemerintah daerah dalam menjalankan program Perkebunan Inti Rakyat-Transmigrasi (PIR-Trans). Pihak perusahaan bekerja dengan broker lokal dan oknum pemerintah membujuk masyarakat untuk melepaskan lahan mereka dengan imbalan kebun sawit dalam program PIR-Trans. Petani-petani dengan kepemilikan tanah yang cocok untuk tanaman sawit ditunjuk oleh pemerintah untuk menjadi peserta program dan diminta untuk menyerahkan 7,5 ha lahan mereka sebagai ganti paket yang terdiri dari 2 ha kebun sawit, 0,5 ha lahan perumahan, rumah kayu dan jatah hidup. Sisa 5 ha akan dibagi menjadi paket yang identik untuk transmigran, dengan sisa 2,5 ha untuk bidang inti perusahaan, jalan, kantor, pabrik pengolahan dan perumahan untuk staf dan pekerja perkebunan. Petani yang berpartisipasi dalam skema ini dipaksa untuk menyetujui pinjaman bank sebesar Rp11,6 juta untuk menutup biaya pengerjaan lahan menjadi kebun sawit.

Untuk memperoleh dukungan, perusahaan biasanya bekerja erat dengan pihak pemerintah daerah dalam memperlancar proses peralihan lahan dari masyarakat karena memang transfer tanah menjadi tanggung jawab pemerintah. Elit desa dan orang berpengaruh biasanya direkrut sebagai mandor dan staf hubungan masyarakat yang ditugasi meyakinkan petani bahwa budidaya kelapa sawit akan baik untuk masa depan mereka dan program pemerintah perlu didukung. Berbagai janji juga disampaikan kepada masyarakat (Prabowo, Maryudi, Senawi, \& Imron, 2017; Semedi \& Bakker, 2014).

Salah satu cara untuk meyakinkan petani agar mau menyerahkan tanahnya, staf perusahaan menunjukkan keberhasilan para pekerja dari Jawa yang bekerja untuk perusahaan. Contoh keberhasilan para pekerja dari Jawa ini menjadi alat mujarab agar petani dan penduduk lokal terbujuk mau menerima sawit dan menyerahkan lahannya untuk dikelola perusahaan melalui skema perkebunan inti rakyat (Semedi \& Bakker, 2014). Informasi yang disebarkan adalah bahwa dengan bekerja atau berkebun sawit maka mereka bisa menyekolahkan anak-anaknya, menerima upah rutin dan akan dianggap maju dan makmur. Ketika pendekatan lunak gagal berfungsi, maka tidak sedikit perusahaan yang mengubah pendekatannya dengan menggunakan cara-cara intimidatif, dengan mulai mengancam masyarakat yang tidak mendukung program pemerintah sebagai bentuk-bentuk melawan pemerintah (Prabowo et al., 2017; Semedi \& Bakker, 2014). Seringkali perusahaan juga meminta kepala dusun untuk mendata lahan-lahan secara kolektif yang akan diserahkan masyarakat ke perusahaan. Seringkali petani tidak memliliki pilihan lain selain memberikan data kepada kepala dusun, terlebih pihak perusahaan sudah mempunyai izin resmi untuk berinvestasi membangun kebun di wilayah mereka (Semedi \& Bakker, 2014).

Dalam penelitiannya di Kalimantan Barat, Prabowo et al. (2017) menemukan fakta bahwa praktik penguasaan lahan oleh perusahaan sawit dilakukan melalui paksaan, penerapan insentif dan disinsentif serta pemberian informasi dalam bentuk janji-janji. Dalam kasus di Sanggau, bentuk paksaan terjadi ketika ada perubahan politik desentralisasi yang lebih memberi kewenangan kepada pemerintah kabupaten. Peraturan-peraturan daerah yang menguntungkan posisi perusahaan, tidak hanya perusahaan yang bergerak di perkebunan kelapa sawit, dimanfaatkan untuk memperluas penguasaan lahan. Kontestasi dan persaingan antar kekuatan dan aktor atas lahan terjadi, yang diindikasikan dengan banyaknya lahan-lahan tumpang tindih. Yang menang dari kontestasi ini, seperti yang terjadi pada kasus di Sanggau, adalah pihak-pihak yang mempunyai sumberdaya yang besar dan diuntungkan oleh momentum perubahan struktural politik. Bentuk-bentuk insentif dan dinsinsentif sering digunakan untuk membangun dukungan kolektif dari masyarakat, dan demikian juga informasi dalam bentuk janji-janji, misalnya untuk merekrut masyarakat lokal sebagai tenaga kerja, memberi royalti, disebarkan untuk menjinakkan kesadaran kritis masyarakat. Pendekatan intimidatif sering ditemukan terjadi di Kalimantan Tengah. Salah seorang responden dari akademisi yang banyak meneliti perkebunan sawit di provinsi tersebut membenarkan fenomena tersebut di atas. 
Hasil analisis persepsi para pihak menunjukkan bahwa akar masalah terjadinya kasus-kasus perkebunan sawit di kawasan hutan antara lain terkait dengan soal ketimpangan struktural $(36,13 \%)$, keserakahan ekonomi (29,41\%), kemiskinan (15,97\%) dan lainnya (18,49\%) (Gambar 4). Ketimpangan struktur dalam hal penguasaan, kepemilikan dan pemanfaatan lahan merupakan masalah akut yang diakibatkan masih dominannya penguasaan perusahaan skala besar terhadap perkebunan. Keserakahan ekonomi juga menjadi bagian dari akar masalah yang didorong oleh liberalisasi pasar dan masih belum optimalnya kontrol negara. Masalah kemiskinan juga muncul dimana ada sekitar 10 juta lebih masyarakat miskin yang tinggal di sekitar dan dalam hutan. Sedangkan akar masalah lainnya adalah terkait dengan tata kelola dan kepemimpinan politik.

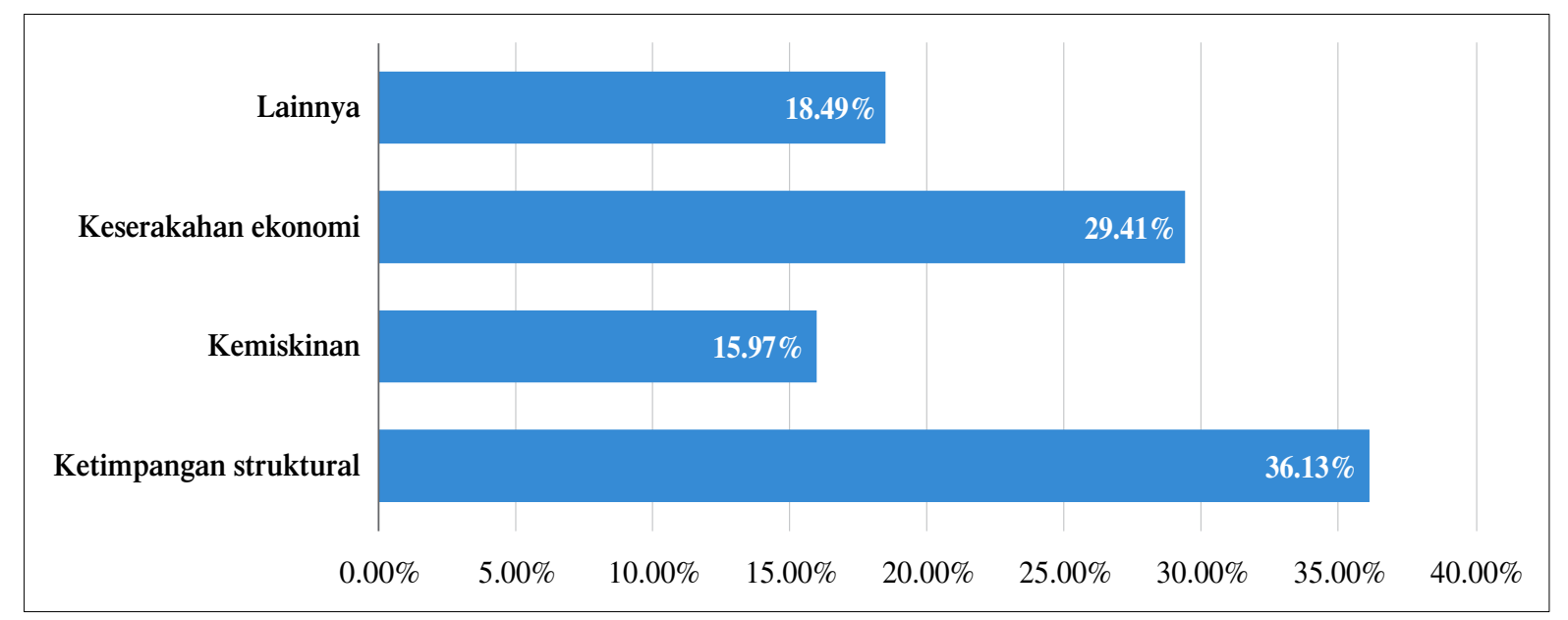

Gambar 4. Akar masalah ekspansi perkebunan sawit dalam kawasan hutan

Sumber: Data primer (2017)

Berdasarkan wawancara dengan 86 responden, baik di tingkat pusat maupun di tingkat daerah di Kalimantan Tengah dan Kalimantan Barat, diperoleh data persepsi terhadap penyelesaian tenurial perkebunan kelapa sawit pada beberapa periode pemerintahan dan faktor-faktor penyebab tumpang tindih perkebunan kelapa sawit di kawasan hutan. Gambar 5 menyajikan kecenderungan meningkatnya performa penyelesaian konflik tenurial melalui berbagai pilihan kebijakan yang dilakukan pemerintah, namun implementasi dari kebijakan-kebijakan tersebut masih belum memenuhi harapan publik, dengan rata-rata nilainya hanya 6,2 .

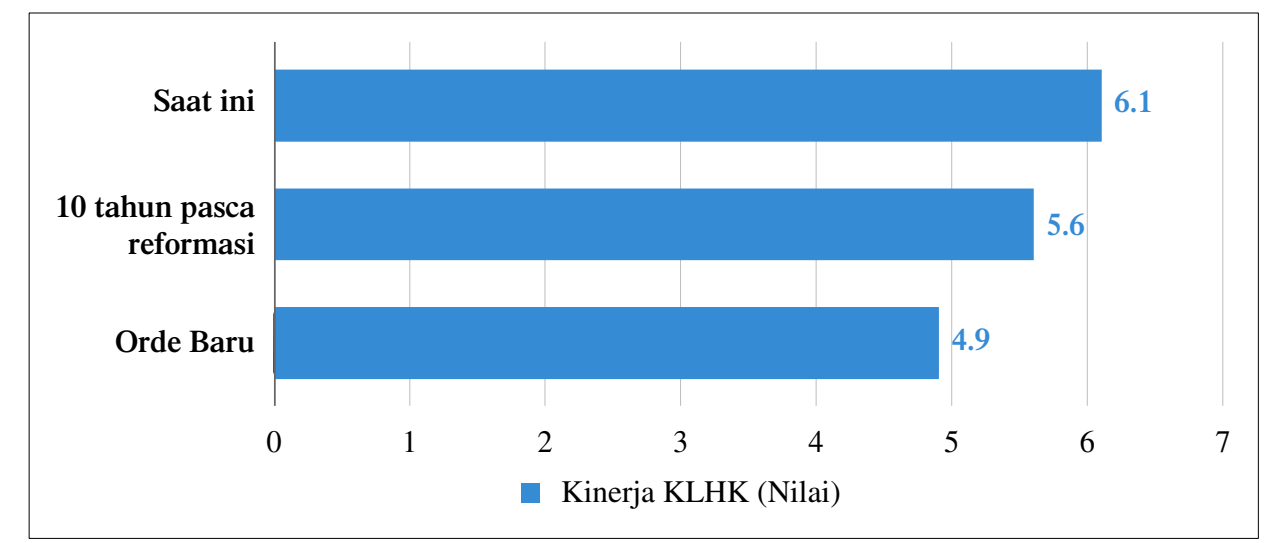

Gambar 5. Penilaian responden terhadap kebijakan penyelesaian perkebunan kelapa sawit di kawasan hutan dari 3 periode pemerintahan yang berbeda $(n=86)$

Sumber: Data primer (2017) 
Menurut responden, faktor-faktor penyebab terjadinya tumpang tindih perkebunan kelapa sawit di kawasan hutan secara berturut-turut adalah lemahnya instrumen regulasi $(30,51 \%)$, yang diikuti oleh belum optimalnya sinergi penanganan masalah oleh pemerintah pusat dan daerah $(25,32 \%)$, belum efektifnya pengawasan pemerintah $(24,02 \%)$ dan belum efektifnya penegakan hukum $(20,12 \%)$ (Gambar 6).

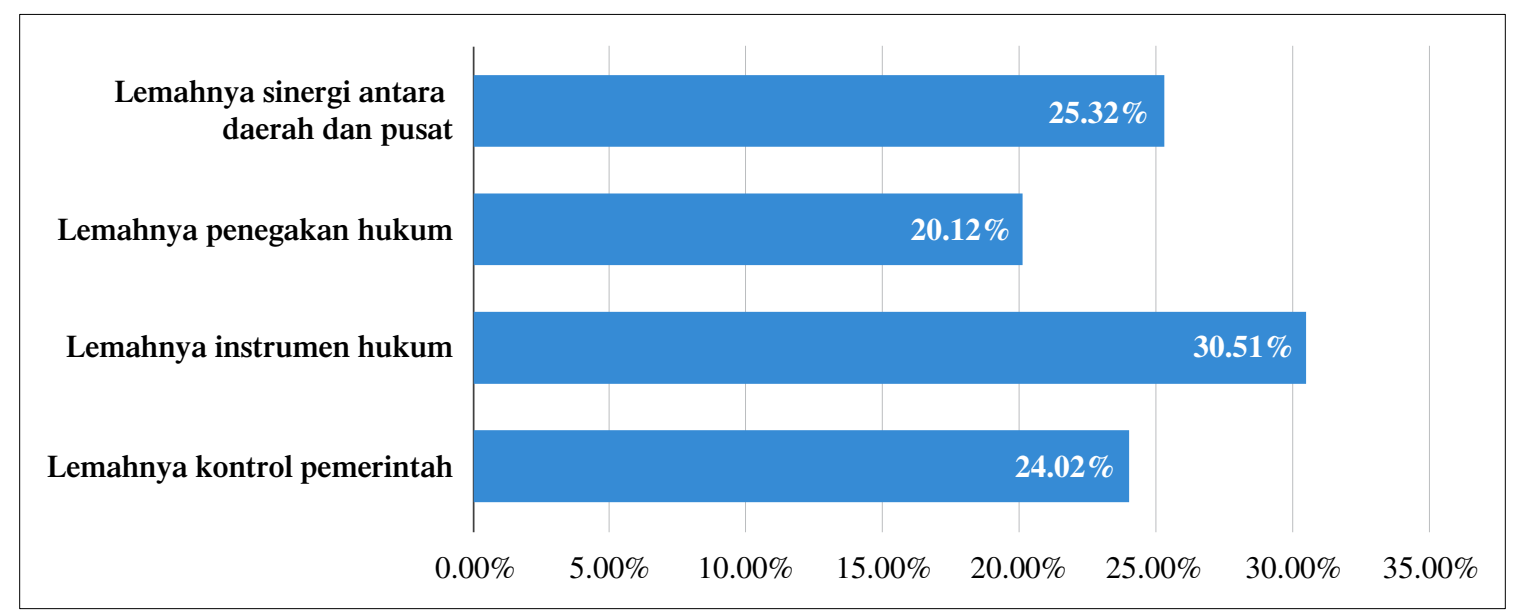

Gambar 6. Penyebab ekspansi sawit di kawasan hutan (Data diolah 2017; n=86)

Sumber: Data primer (2017)

Selain aspek tata kelola, faktor-faktor penyebab lain juga memiliki korelasi dengan perluasan perkebunan kelapa sawit di kawasan hutan, seperti diilustrasikan pada Gambar 7. Faktor sosial menduduki posisi yang paling tinggi $(35,54 \%)$, yang meliputi kecemburuan sosial, terbangunnya mitos sawit sebagai satu-satunya komoditas yang paling menguntungkan dan paparan informasi yang tidak utuh yang diterima oleh masyarakat. Faktor ekonomi menduduki posisi kedua $(33,88 \%)$ yang berkorelasi dengan meningkatnya penguasaan kawasan hutan untuk kepentingan perkebunan kelapa sawit. Banyak petani termotivasi untuk membuka lahan di kawasan hutan karena cepatnya keuntungan yang telah diterima dengan harga yang relatif stabil. Faktor lain adalah politik $(30,58 \%)$, khususnya terkait dengan pemilihan umum kepala daerah yang berkelindan dengan upaya konsolidasi sumberdaya material untuk kekuasan politik.

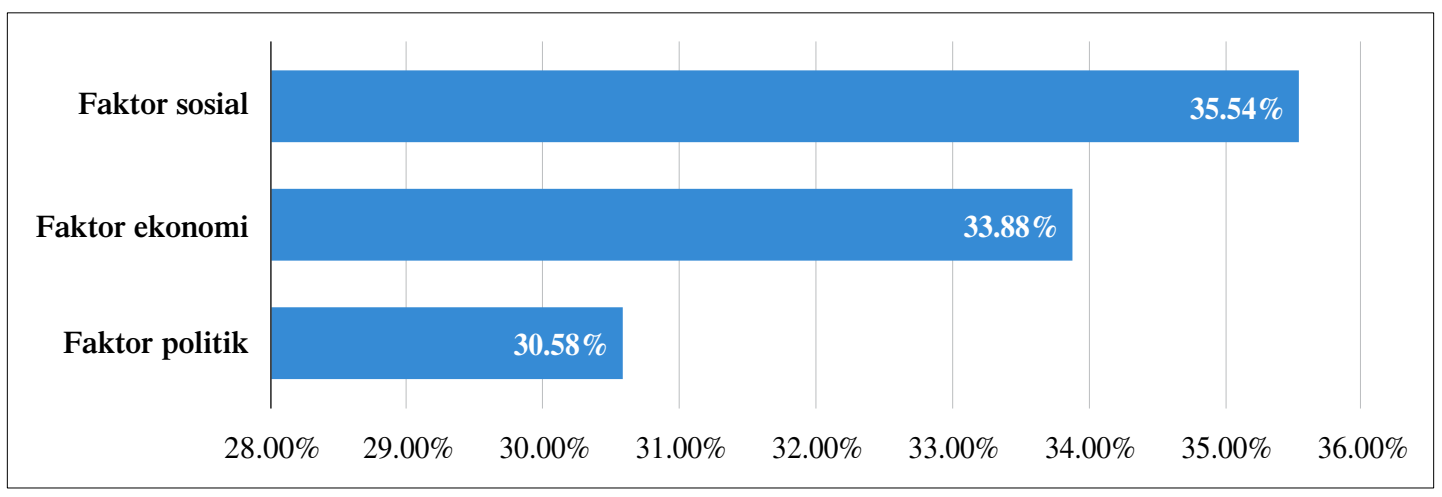

Gambar 7. Faktor lain dari ekspansi perkebunan kelapa sawit dalam kawasan hutan

Sumber: Data primer (2017) 


\subsection{Praktik dan strategi masyarakat dalam penguasaan lahan}

Perkebunan kelapa sawit rakyat mulai aktif berkembang sejak pemerintahan Orde Baru pada tahun 1970an yang didukung oleh Bank Dunia melalui skema Perkebunan Inti Rakyat (PIR). Program PIR ini menjadi sarana pembangunan sosial dan ekonomi lokal dan bagian dari penguatan integrasi politik wilayah luar Jawa (Molenaar, Persch-Orth, Lord, Taylor, \& Harms, 2013). Perkembangan PIR terkait dengan keberadaan perusahaan perkebunan milik negara dan perusahaan swasta yang berperan dalam memberikan input sarana produksi, bantuan teknis dan keuangan. Ketika biaya pembangunan plasma telah dibayarkan kembali ke perusahaan, penguasaan formal lahan dikembalikan ke petani yang telah menyerahkan lahannya untuk program ini. Akibat adanya kritik internasional, dalam periode 1980an skema tersebut tidak aktif lagi dikembangkan oleh pemerintah melalui perusahaan perkebunan negara (J. F. McCarthy, Gillespie, \& Zen, 2012), dan perusahaan besar swasta kemudian mulai mengambil alih peran aktif mengembangkan plasma (Zen, Barlow, Gondowarsito, \& McCarthy, 2016).

Luas perkebunan sawit rakyat melalui skema PIR di seluruh wilayah Indonesia diperkirakan mencapai 700,000 ha (Badrun, 2011) sampai 900,000 ha (Zen et al., 2016). Secara keseluruhan, perkebunan rakyat mencakup lebih dari $40 \%$ dari total luas perkebunan kelapa sawit dan 35\% dari total minyak mentah produksi minyak kelapa sawit nasional (Direktorat Jenderal Perkebunan, 2015). Data terbaru perkebunan sawit rakyat menunjukkan luasannya telah mencapai 5,6 juta ha (Direktorat Jenderal Perkebunan, 2018a), yang tersebar di 18 provinsi (Daemeter Consulting, 2015) dan mayoritas dari perkebunan rakyat tersebut termasuk dalam kategori swadaya (Jelsma, Schoneveld, Zoomers, \& van Westen, 2017).

Di Kalimantan Tengah, perkebunan rakyat telah mencapai luas 143.058 ha, produksi 235.921 ton dengan tingkat produktivitas 2,1 ton per ha. Petani yang terlibat di dalam usaha perkebunan rakyat tersebut tercatat 61.828 orang. Di Kalimantan Barat, total luas perkebunan sawit rakyat mencapai 365.215 ha dengan produksi 543.084 ton. Tingkat produktivitas kebun rakyat di Kalimantan Barat lebih rendah yakni 1,9 ton per ha, dengan petani yang terlibat sebanyak 110.557 (Direktorat Jenderal Perkebunan, 2015).

Perkebunan swadaya umumnya berkembang tanpa dukungan dari pemerintah (J. F. McCarthy \& Zen, 2016). Kurangnya bantuan dan dukungan dari pemerintah disebabkan karena perkebunan sawit swadaya banyak berada di luar jangkauan kendali pemerintah. Pekebun swadaya umumnya sangat menggantungkan pada lahan-lahan yang belum jelas hak legalitasnya. Hal ini berbeda dengan pekebun plasma yang status lahannya jelas, karena diperoleh berbarengan dengan (menjadi bagian dari) lahan yang dimohonkan perusahaan melalui rosedur peraturan perundang-undangan yang berlaku terkait izin lokasi, pelepeasan kawasan dan HGU. Pemasaran hasil TBS dari pekebun swadaya juga cenderung tidak jelas dan tetap dan sangat tergantung pada keberadaan middleman yang mempunyai hubungan dengan pabrik perusahaan. Petani swadaya seringkali dianggap sebagai petani yang terbelakang dan marginal dibandingkan dengan halnya petani PIR yang dicirikan dengan sistem pertanian modern (J. F. McCarthy \& Zen, 2016). Dalam rantai pasok, peran pekebun swadaya sangat penting namun keberadaan kebun yang tersebar dan jaringan perdagangan TBS yang cukup kompleks menjadi tantangan di dalam memastikan tingkat penelusuran produk yang berkelanjutan (traceability), seperti yang dituntut dalam sistem sertifikasi seperti RSPO (Jelsma et al., 2017).

Belum ada definisi yang tepat untuk petani sawit rakyat, tetapi dalam praktiknya cenderung merujuk pada kriteria luas lahan yang dikuasai dan tenaga kerja buruh yang berasa dari keluarga petani itu sendiri (Cramb \& Sujang, 2016). (Roundtable on Sustainable Palm Oil, 2016) mendefinisikan petani sawit skala kecil sebagai petani yang menanam sawit bersama-sama dengan tanaman subsisten lainnya, dimana keluarga petani mengerjakan sebagian besar pekerjaan berkebun dan kebun sawit tersebut menjadi sumber pendapatan utama, dengan luasan kebun sawit kurang dari 50 ha. Pekebun swadaya dicirikan dengan kebebasan untuk memilih cara mereka mengerjakan lahan, jenis tanaman dan cara-cara mereka mengelola kebun. Mereka tidak terikat kontrak dengan pabrik pengolahan atau asosiasi dan juga kurang menerima dukungan dan bantuan penyuluhan dari instansi pemerintah. 
Menteri Pertanian melalui Peraturan Menteri Pertanian No.98/Permentan/OT.140/9/2013 mengatur jenis dan perizinan usaha perkebunan dan secara khusus mendefinisikan pekebun sebagai perorangan warga negara Indonesia yang melakukan usaha perkebunan dengan skala usaha tidak mencapai skala tertentu. Tidak ada batasan pasti luasan yang dapat diusahakan oleh pekebun sawit, tetapi diatur dalam peraturan tersebut bahwa usaha budidaya tanaman perkebunan dengan luas kurang dari 25 ha didaftarkan oleh bupati dan pemiliknya diberikan Surat Tanda Daftar Perkebunan (STD-B).

Praktik dan strategi masyarakat dalam menguasai lahan umumnya diawali dengan cara membuka lahan, baik yang mereka yakini sebagai miliknya, warisan dari pendahulunya maupun yang tidak jelas kepemilikannya. Mereka membabat tegakan kayu dan melakukan pembersihan yang kemudian diikuti penanaman. Saat membuka lahan, termasuk di lahan-lahan yang kemudian diketahui berada di dalam kawasan tahun, mereka biasanya lebih dulu memasang patok-patok kayu untuk menandai calon lahanlahan mereka. Kalau ada satu anggota masyarakat yang melakukan pematokan, tidak lama kemudian biasanya diikuti oleh anggota masyarakat lainnya. Masyarakat tergerak untuk membuka lahan di dalam kawasan hutan biasanya setelah mendengar informasi akan adanya pendirian perusahaan perkebunan sawit.

Tidak semua warga memiliki motivasi yang sama dalam membuka kebun sawit. Sebagian warga hanya ingin menjual lahannya ke perusahaan, dan bukan untuk ditanami sendiri. Sebagian lain membuka dan menggunakan lahan tersebut sebagai alat klaim milik nenek moyang mereka dengan menanam pepaya atau pisang, sehingga kalau ada pengecekan, klaim mereka bisa dibuktikan dengan tanaman pisang atau pepaya mereka. Masyarakat bermodal kecil biasanya mencari lahan dengan cara memanfaatkan hubungan dengan teman atau elit lokal untuk melakukan jual beli lahan. Sedangkan petani bermodal dengan penguasan lahan lebih luas dari 25 ha biasanya memanfaatkan orang-orang lokal untuk membuka dan mengusahakan lahan dan menempatkan mereka sebagai buruh atau pendukung dalam proses pencalonan dalam pemilihan kepala daerah atau calon legislatif.

Untuk memperkuat dasar hukum, berbarengan dengan saat mereka membuka lahan atau ketika akan melakukan penanaman, para pekebun sawit mengurus surat keterangan dari kantor desa berbekal informasi terbatas yang mereka miliki. Bentuk legalitas kepemilikan pekebun atas lahan sawit terdiri dari berbagai bentuk, sebagian ada yang memiliki sertifikat hak milik (SHM), tetapi sebagian besar pekebun hanya mempunyai bukti legalitas dalam bentuk surat keterangan tanah (SKT), surat pernyataan tanah (SPT) atau surat keterangan tanah adat (SKTA) (Jelsma et al., 2017; Winrock International, 2017).

Pelaku pembuka lahan di dalam kawasan hutan melibatkan jaringan yang luas, tidak hanya masyarakat lokal tetapi juga banyak pendatang Semedi \& Bakker (2014) menegaskan bahwa banyak investor kota yang tertarik dengan investasi kebun sawit di wilayah-wilayah pedalaman seperti di Buayan, Kabupaten Sanggau, Kalimantan Barat. Adanya kemudahan membuka lahan di kawasan hutan dan daya tarik keuntungan yang diperoleh dari usaha kebun sawit telah memicu arus migrasi yang signifikan atau dalam bentuk eksodus seperti orang-orang Sumatera yang umumnya memiliki daya bertahan hidup luar biasa sekalipun harus tinggal di daerah-daerah pedalaman. ${ }^{8}$ Berdasarkan penelitian di Riau, Jelsma et al. (2017) menemukan bahwa di daerah pedalaman dan bukaan baru hanya $26,4 \%$ perkebunan sawit rakyat yang berada di APL, sementara sebagian besar sisanya berpotensi tumpang tindih dengan kawasan hutan. Investor atau pemilik kebun di daerah pedalaman dengan penguasaan yang rata-rata jauh lebih luas dari pekebun umumnya, sekitar $78,2 \%$ nya berasal dari luar kabupaten. Etnis dari Sumatera Utara juga tercatat menguasai $54 \%$ dari seluruh suku pemilik kebun yang dikategorikan investor besar dengan kepemilikan kebun lebih dari 15 ha. Santoso (2018) menggambarkan booming komoditas sawit yang menyebabkan terjadinya perburuan lahan dan perambahan kawasan hutan yang cukup masif oleh masyarakat di Kab. Aceh, yang kemudian memicu komersialisasi dan jual beli lahan hutan dari warga tempatan kepada para pendatang, yang disebutnya sebagai ekonomi perjudian.

8 Berdasarkan wawancara dengan nara sumber dari sebuah LSM nasional 
Seorang aktivis agraria menjelaskan bahwa apa yang telah dilakukan oleh masyarakat dengan merambah hutan untuk dibangun kebun sawit sesungguhnya merupakan pilihan rasional mereka karena tidak mempunyai pilihan lain. Umumnya masyarakat kecil hanya membuka lahan sekitar 2-4 ha untuk dibangun kebun sawit dalam rangka memenuhi kebutuhan mereka sendiri, namun tidak menutup kemungkinan adanya beberapa orang yang melakukan akumulasi lahan. Li (2017) menyatakan bahwa meskipun tidak ada data resmi terkait dengan kebun sawit seperti ini, tetapi banyak kebun sawit ilegal seluas 50-500 ha yang dimiliki dan dijalankan oleh oknum pejabat. Schoneveld et al. (n.d.) menunjukkan bahwa dua kelompok petani sawit swadaya, yakni petani usahawan dan elit lokal, dengan rata-rata penguasaan areal yang luas antara 7 sampai 15 ha, cenderung membangun kebunnya di dalam kawasan hutan.

Penelitian baru-baru ini menunjukkan ada peningkatan kelas petani 'elit' lokal melalui proses akumulasi lahan dan modal. Untuk menghindari kewajiban memiliki izin usaha, para elit ini membagi area perkebunan mereka ke beberapa nama yang luasannya kurang dari batas 25 ha untuk didaftarkan. Petani semacam itu secara efektif menjadi 'tuan tanah' yang baru muncul dan umumnya memiliki sumber pendapatan yang lain, juga sering memegang posisi kekuasaan dalam sistem sosial dan politik lokal. Luas hak kepemilikan tanah yang sesuai untuk petani kecil saat ini tidak jelas dan membutuhkan investigasi lebih lanjut (Daemeter Consulting, 2015).

Meluasnya perkebunan sawit oleh petani swadaya berbarengan dengan kemunculan aktor-aktor baru yang mengoperasikan kebun sawit dengan luas ratusan hektar. Pembangunan kebun di wilayah pedalaman secara spontan ini berada di luar kendali pemerintah. Observasi lapangan menemukan fenomena bahwa perluasan perkebunan sawit oleh petani swadaya dan aktor-aktor individual lain melibatkan spekulan lahan dan transfer lahan secara masif. Masyarakat lokal memainkan peran penting dalam memfasilitasi ekspansi lahan perkebunan sawit tersebut. Data lapangan tahun 2013 mengungkapkan bahwa $71 \%$ petani sawit swadaya membeli lahan dari masyarakat lokal dan sebagian besar dari mereka adalah para komunitas migran (Budidarsono, Sirait, \& Pradhan, 2014). Tidak jelasnya legalitas lahan membuat harga lahan menjadi murah (Krishna, Kubitza, Pascual, \& Qaim, 2017). Lebih jauh lagi, 13\% petani sawit lokal memperoleh lahan dengan cara mengokupasi lahanlahan terlantar sekitar desa mereka (Budidarsono et al., 2014; Krishna et al., 2017).

Tidak ada data yang dapat dipercaya tentang luas lahan petani tanpa sertifikat hak milik (SHM) yang dikeluarkan oleh Badan Pertanahan Nasional. Asosiasi Petani Kelapa Sawit Indonesia memperkirakan bahwa 90\% dari luas kebun plasma tidak mempunyai alas legal formal. Hasil studi SPKS menunjukkan hanya $27 \%$ saja dari petani responden yang mempunyai hak atas lahan (Winrock International, 2017). Pemilik kebun umumnya enggan untuk mengurus SHM karena prosesnya yang panjang dan berbiaya tinggi, yakni sekitar Rp 4 juta per dua hektar bidang tanah, dan mereka juga khawatir tanah mereka akan dikenai pajak (Daemeter Consulting, 2015; Jelsma et al., 2017). 


\section{Perkembangan perkebunan kelapa sawit dan permasalahan tenurial di Kalimantan Tengah}

\subsection{Perkembangan perkebunan kelapa sawit di Kalimantan Tengah}

Berdasarkan Peraturan Daerah No 5/2015 tentang Rencana Tata Ruang Wilayah Provinsi Kalimantan Tengah Tahun 2015-2035 dan Peraturan Menteri Kehutanan No. 529/Menhut-II/2012 tentang penunjukan areal hutan di wilayah Provinsi Kalimantan Tengah, dari luas wilayah provinsi yang mencapai lebih dari 15,3 juta ha, sekitar $83 \%$ nya atau 12,7 juta adalah kawasan hutan. Gambar 8 menyajikan peta sebaran dan luasan kawasan hutan di berbagai fungsi. Dari luas kawasan hutan tersebut, sekitar 2,5 juta merupakan Hutan Produksi Konversi (HPK) yang potensial untuk dialokasikan bagi pembangunan di luar kehutanan, termasuk perkebunan. Luas Areal Penggunaan Lain (APL) yang sudah dialokasikan untuk perkebunan kelapa sawit dan peruntukan lainnya mencapai 2,5 juta ha.

Secara historis, Sulaeman (2009) menceritakan bahwa perkebunan kelapa sawit di Kalimantan Tengah mulai berkembang pada tahun 1981 menyusul hasil identifikasi yang dilakukan Lembaga Penelitian Tanah (LPT) Bogor yang menunjukkan bahwa sekitar 3.195.000 ha dari luas wilayah 15.356.700 ha di provinsi ini cocok untuk dikembangkan untuk berbagai jenis tanaman.
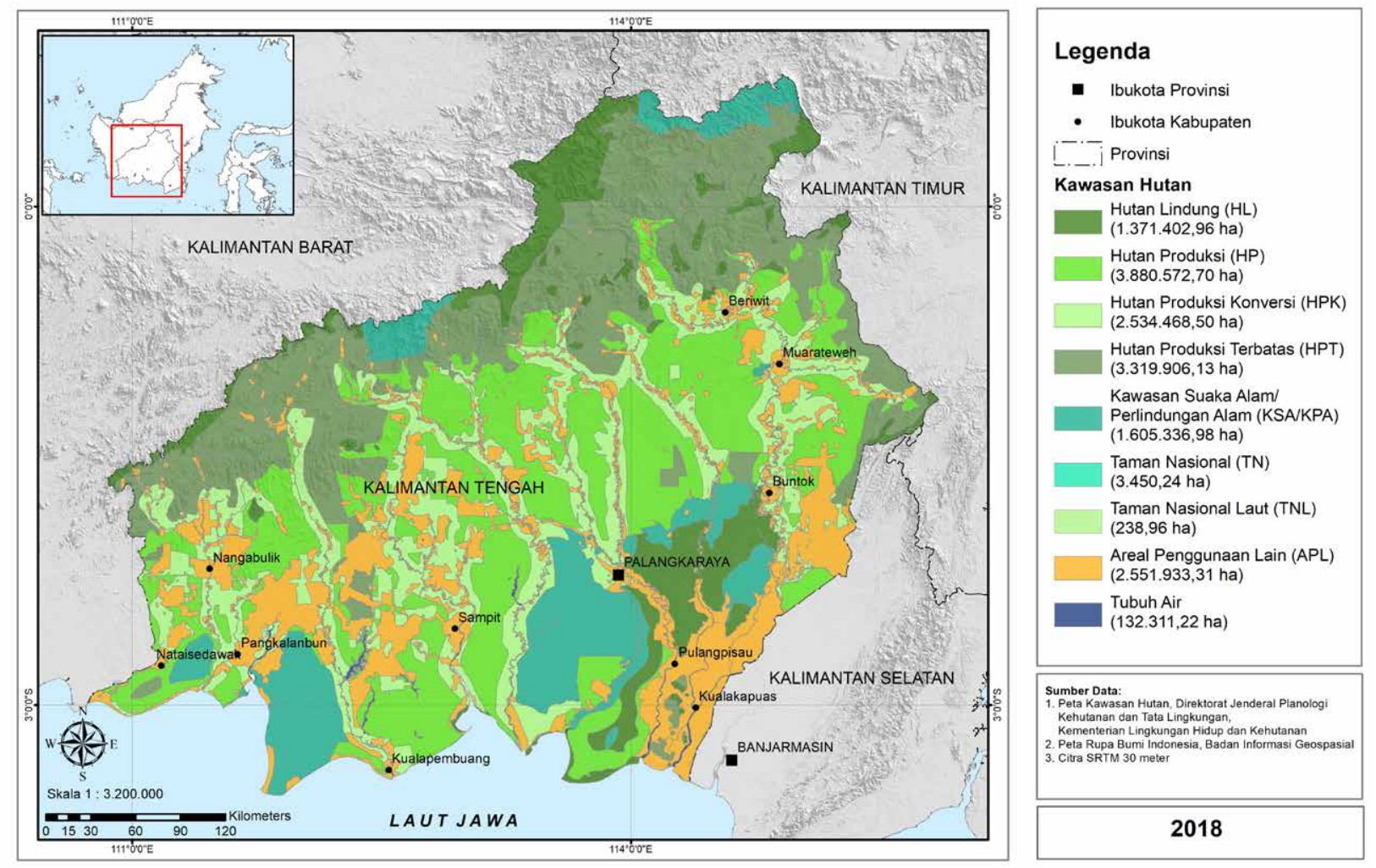

Gambar 8. Sebaran dan luasan kawasan hutan Provinsi Kalimantan Tengah

Note: Angka luas kawasan merupakan hasil analisis data spasial dan perhitungan, yang mungkin bisa berbeda dengan angka luasan resmi dari Kementerian Lingkungan Hidup dan Kehutanan.

Sumber: Analisis spasial (2018) 
Pada tahun 1984 disusun Rencana Induk Pengembangan Perkebunan (RIPP) Kalimantan Tengah, yang memasukan kelapa sawit sebagai salah satu tanaman yang cocok pada iklim A, kelas tanah III dan IV serta jenis tanah podsolid merah kuning. Pada Tahun 1992, masuk investor PT. Indo Turba Tengah bekerjasama dengan Angkatan Darat melalui Yayasan Kartika Eka Paksi yang didukung Salim Group di lokasi eks transmigrasi Amin Jaya di Kabupaten Kotawaringin Barat. Atas gagasan wakil gubernur Kalimantan Tengah, lokasi transmigrasi umum di Desa Amin Jaya yang ditinggalkan oleh penghuninya pada awalnya akan digantikan dengan Transmigrasi Angkatan Darat (TRANSAD) khusus bagi para pensiunan aparat militer angkatan darat. Namun rencana tersebut juga batal dilaksanakan. Pada tahun 1993, PT. Agro Astra Lestari bekerjasama dengan 10 perusahaan melakukan investasi perkebunan kelapa sawit di Desa Runtu Kabupaten Kotawaringin Barat (Sulaeman, 2009).

Perda No. 3 Tahun 1993 tentang Tata Ruang Kalimantan Tengah akhirnya memberi kemudahan bagi investor perusahaan kelapa sawit berinvestasi. Sampai 30 Juni 2009, tercatat ada 302 perusahaan perkebunan kelapa sawit dengan luasan 4.011.032 ha, yang terdiri dari perusahaan belum operasional 158 dengan luas 2.323 .063 ha dan yang operasional 144 dengan luasan 1.687 .969 ha. Dari 144 buah perusahaan kelapa sawit yang operasional tersebut TBS yang diproduksi mencapai 6.454.370 ton (data Tahun 2008) sementara CPO mencapai 1.290 .874 ton, yang berasal dari areal yang sudah tertanam seluas 632.446 ha. Investasi kebun, infrastruktur dan lain-lain mencapai Rp15,8 triliun ditambah investasi pabrik Rp6,5 triliun (Sulaeman, 2009).

Dalam beberapa tahun terakhir, berbagai investasi berbasis lahan mengalami peningkatan di beberapa wilayah kabupaten dan sebagian masuk ke wilayah pedalaman Kalimantan Tengah. Data (WALHI, 2017) menunjukkan sekitar $78 \%$ dari luas wilayah provinsi kini telah berubah menjadi areal konsesi lewat berbagai bentuk izin pengusahaan dan pengelolaan yang dikeluarkan oleh Kementerian Kehutanan atau pemerintah daerah. Sampai 2017, tercatat ada 323 perusahaan perkebunan kelapa sawit yang menguasai lahan seluas 4.051.416 ha. ${ }^{9}$ Selain perusahaan, perkebunan rakyat dan perkebunan perusahaan negara juga ikut berkontribusi pada besaran luas dan produksi kelapa sawit di provinsi ini, yang antara periode 2015-2017 terus mengalami perkembangan (Gambar 9).

Perkembangan perkebunan kelapa sawit yang cukup pesat diikuti oleh peningkatan investasi di provinsi ini (Gambar 10). Subsektor perkebunan kelapa sawit menempati peringkat kedua dalam hal penguasaan atas lahan.

\subsection{Peta konflik tenurial perkebunan kelapa sawit}

Proses tata ruang wilayah di Provinsi Kalimantan Tengah berlangsung sangat dinamis sejak berlakunya Tata Guna Hutan Kesepakatan (TGHK) pada 1982 yang menetapkan kawasan hutan dengan berbagai fungsi (Gambar 5). Paska berlakunya TGHK, pada 1993 pemerintah daerah mengeluarkan Perda No 5/1993 tentang Rencana Tata Ruang Wilayah Provinsi, yang sepuluh tahun kemudian pada 2003 dikukuhkan menjadi Perda No 8/2003. Perda tersebut mengatur pembagian proporsi kawasan hutan yang diperkuat dengan keluarnya Keputusan Menteri Kehutanan No. 292/2011. Pada 2012, Menteri Kehutanan mengeluarkan SK Menhut No. 529/2012 dan tiga tahun kemudian pada 2015, pemerintah daerah mengeluarkan Perda No. 5/2015 (Setiawan, Maryudi, Purwanto, \& Lele, 2017).

Sampai dengan 2012, Kalimantan Tengah merupakan salah satu provinsi yang belum menyelesaikan tata ruang karena belum terpadu dan serasinya tata ruang kehutanan dan tata ruang wilayah provinsi (Setiawan et al., 2017). Proses paduserasi tersebut seharusnya sudah selesai dilakukan dalam kurun waktu 1992-1999 (Kartodihardjo, 2008). Kondisi tersebut mengakibatkan terjadinya tumpang tindih penggunaan ruang, termasuk perkebunan kelapa sawit di dalam kawasan hutan yang perizinannya tidak diperoleh melalui cara-cara prosedural. Luas tumpang tindih tersebut ditaksir

9 Selain perkebunan kelapa sawit, terdapat 759 perusahaan sektor kehutanan yang menguasai lahan seluas 4.932.145,49 ha dan 563 perusahaan yang bergerak di sektor pertambangan dengan penguasaan lahan seluas 3.310. 490, 44 Ha. 


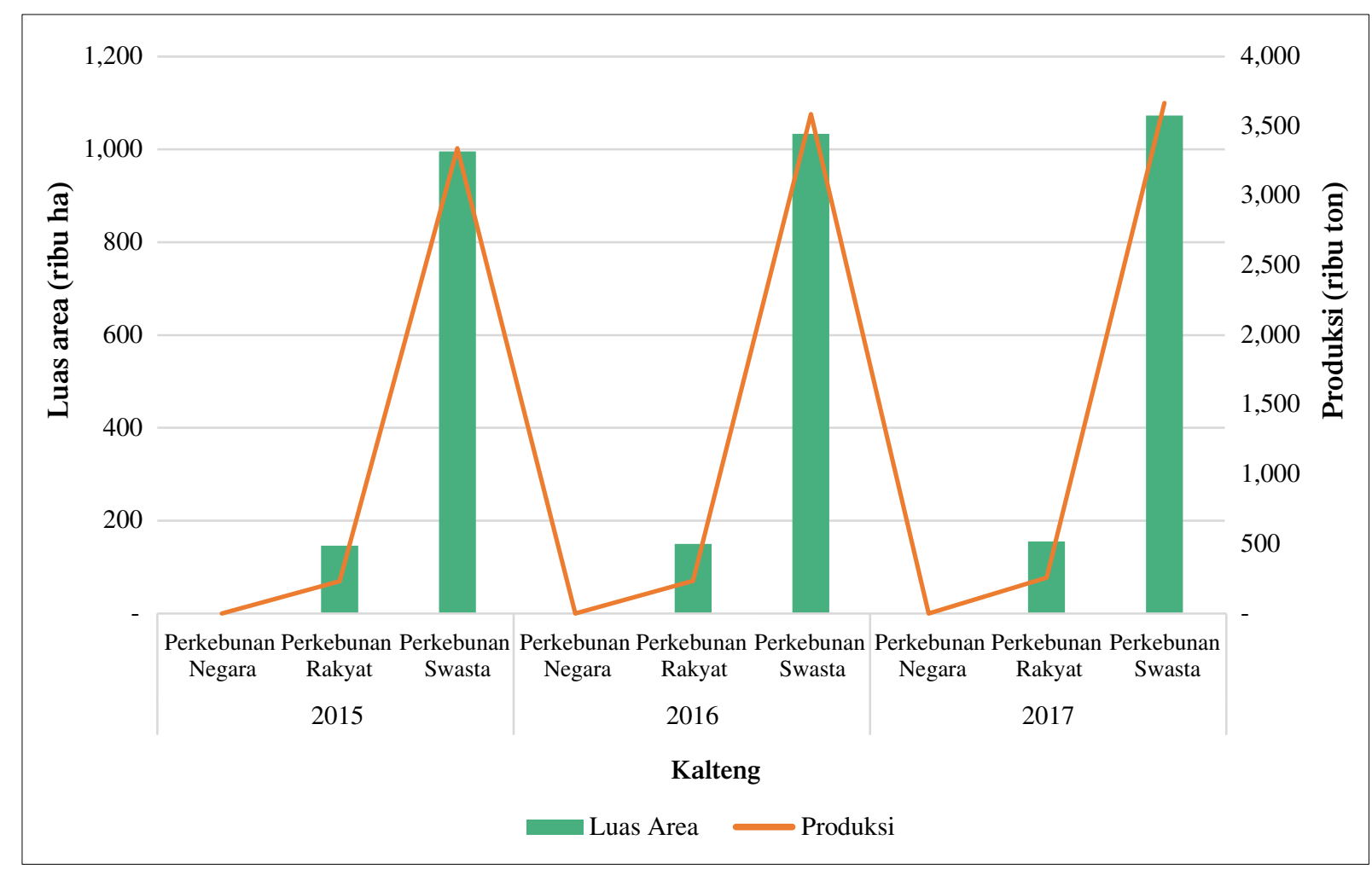

Gambar 9. Perkembangan luas dan produksi perkebunan kelapa sawit rakyat, negara dan swasta tahun 2015-2017 di Provinsi Kalimantan Tengah

Sumber: Statistik Perkebunan 2017 (data diolah)

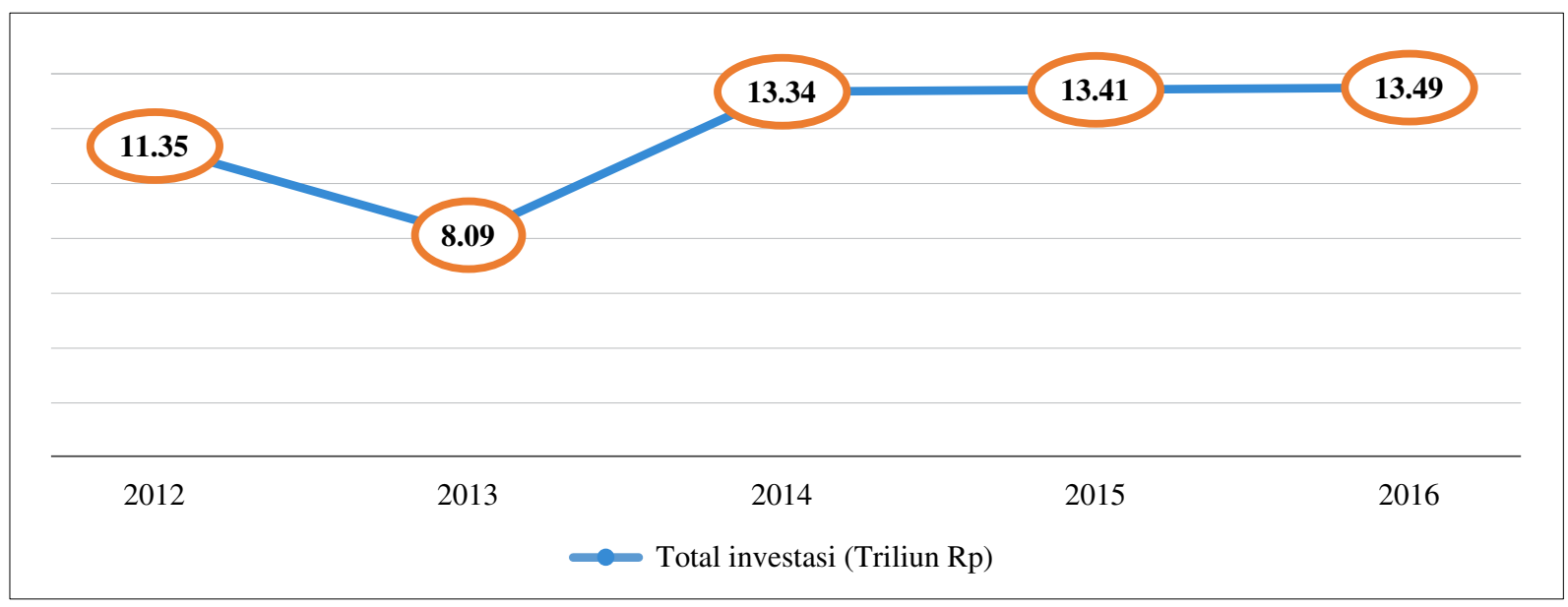

Gambar 10. Perkembangan investasi di Provinsi Kalimantan Tengah (triliun Rp)

Sumber: WALHI (2017)

mencapai luasan 3,9 juta ha perkebunan kelapa sawit, yang dikelola oleh sekitar 282 unit perusahaan (Setiawan et al., 2017). Dinamika konflik keruangan tersebut memunculkan apa yang disebut sebagai 'keterlanjuran,'dimana beberapa perusahaan perkebunan sawit yang dulunya berada di KPPL kemudian akhirnya masuk di kawasan hutan (Gambar 11).

Sekitar 1,5 juta ha lahan milik perusahaan perkebunan kelapa sawit di Provinsi Kalimantan Tengah diduga terindikasi ilegal karena menggunakan kawasan hutan (Tempo, 2016). Gubernur Kalimantan Tengah mencatat ada 47 perusahaan penanaman modal asing dengan penguasaan areal sekitar 400.000 ha. 


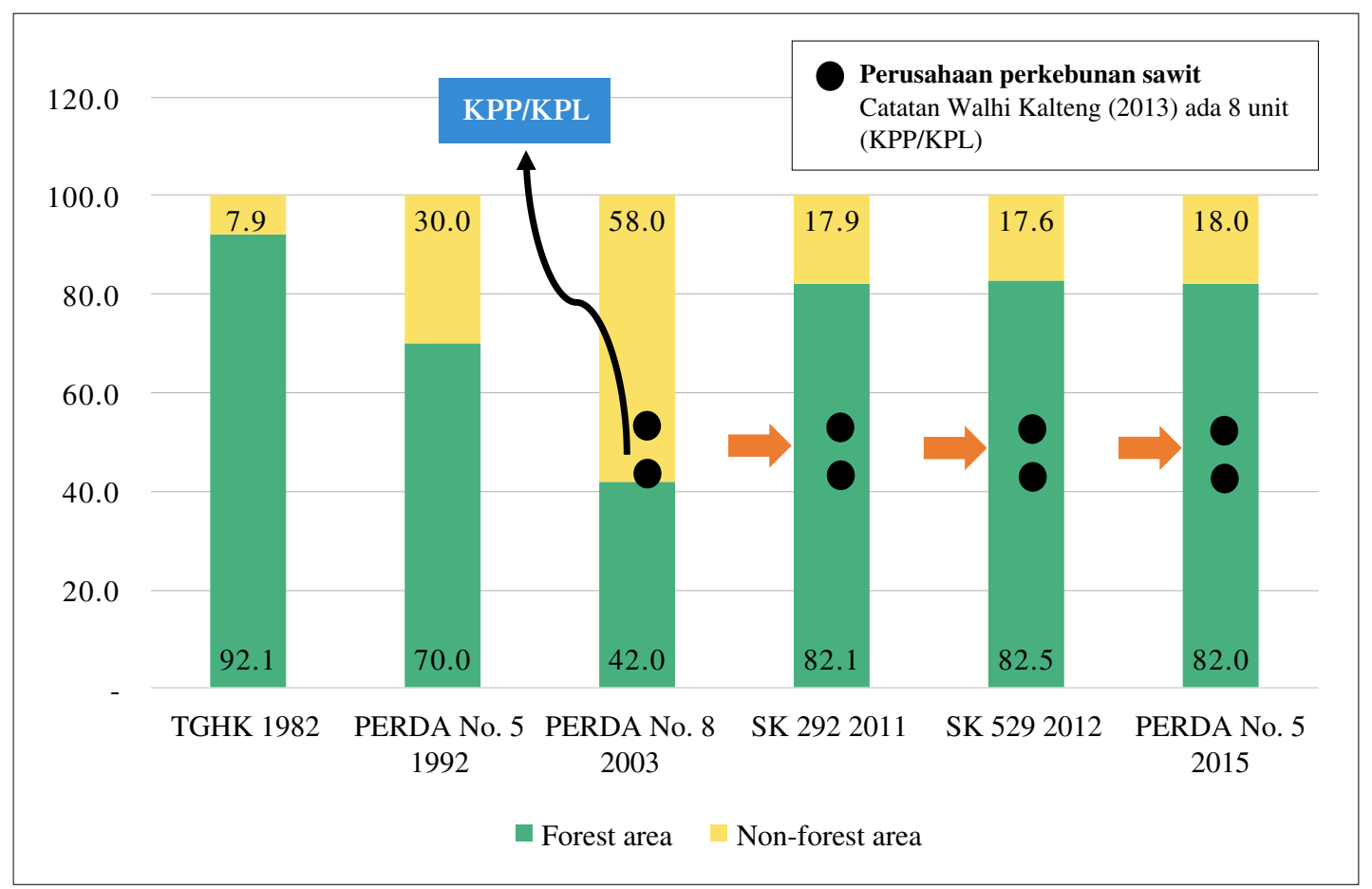

Gambar 11. Dinamika konflik ruang dan keterlanjuran perkebunan kelapa sawit

Sumber: AURIGA (2017)

Dari jumlah itu, 17 diantaranya diketahui ilegal (Kompas, 2017). AURIGA (2017) menemukan areal perkebunan kelapa sawit seluas 152.475 ha yang sudah dibebani HGU yang tumpang tindih dengan kawasan hutan pada berbagai fungsi dan izin pemanfaatan hutan. Gambar 12 menggambarkan sebaran wilayah perkebunan kelapa sawit yang sudah memperoleh HGU yang tumpang tindih antara lain dengan hutan lindung dengan luasan mencapai 4.178 ha, hutan konservasi 234 ha, hutan produksi 82.436 ha, hutan produksi terbatas 19.139 ha, IUPHHK-HTI 36.969 ha dan IUPHHK-HA seluas 9.520 ha.

Total luas perkebunan dengan berbagai komoditas yang terindikasi berada di dalam kawasan hutan di Kalimantan Tengah diperkirakan mencapai 1,7 juta yang tersebar di 14 kabupaten (BPKH, 2018). Hasil analisis spasial dari penelitian ini menunjukkan luas perkebunan kelapa sawit yang berada dalam kawasan hutan di Provinsi Kalimantan Tengah mencapai 894.841 ha. ${ }^{10}$ Dari luasan total tersebut, perkebunan yang berada di dalam kawasan hutan dengan fungsi HP dan HPK mencakup proporsi luas yang hampir sama yakni masing-masing sekitar 43\%. Perkebunan kelapa sawit juga diketahui berada di kawasan HL dan bahkan kawasan suaka alam atau kawasan pelestarian alam (KSA/KPA), sekalipun angka persentasenya kecil (Gambar 13).

Untuk memahami lebih rinci, sebaran perkebunan kelapa sawit di beberapa kabupaten studi dianalisis lebih lanjut. Di Kabupaten Kotawaringin Timur, misalnya, diketahui terdapat 338.251 ha perkebunan kelapa sawit yang berada di dalam kawasan hutan (Gambar 14), yang sebagian besar berada pada HPK $(55,8 \%)$ dan HP $(35,2 \%)$. Sebagian kecil areal perkebunan lainnya tersebar berada di hutan lindung $(0.3 \%)$ dan hutan produksi terbatas $(8,7 \%)$.

10 Dua nara sumber yang diwawancarai mengakui adanya HGU perkebunan yang berada di dalam kawasan hutan. Sekalipun dugaan tersebut disangkal oleh staf pertanahan setempat, namun diakui bahwa saat ada pertemuan pembahasan tentang tata ruang, pihak terkait menyajikan data-data izin yang berada di kawasan hutan tanpa menyebutkan nama perusahaan. Ini mengindikasikan adanya perkebunan dalam kawasan hutan, dan alasan tidak dibukanya informasi mengenai nama-nama perusahaan lebih disebabkan pertimbangan teknis agar iklim investasi di provinsi ini tidak terganggu. 


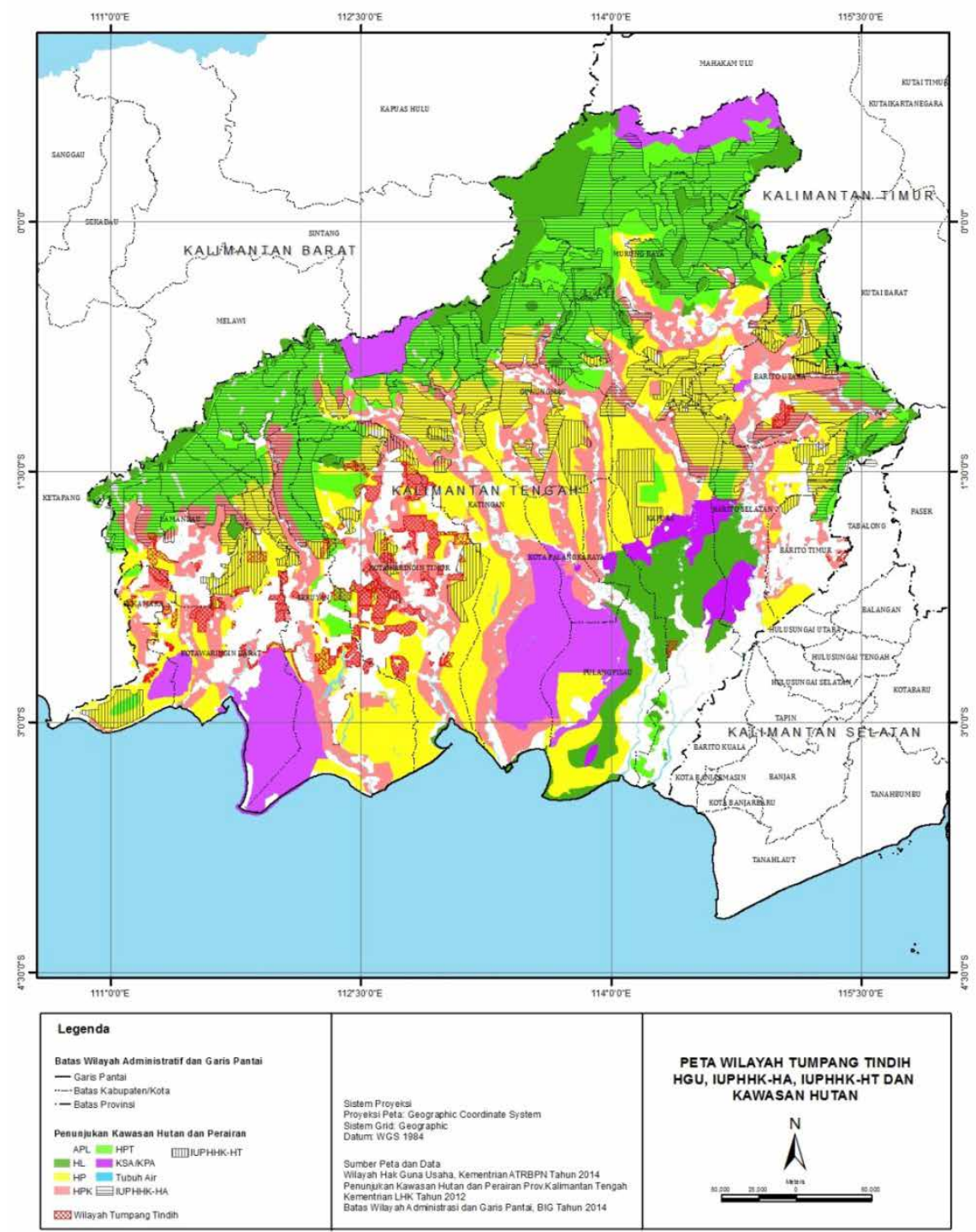

Gambar 12. Areal HGU perkebunan kelapa sawit di kawasan hutan dan izin pengelolaan hutan di Provinsi Kalimantan Tengah

Sumber: AURIGA (2017)

Total luas perkebunan kelapa sawit rakyat yang teridentifikasi di Kab. Kotawaringin Barat mencapai 43.784 ha sementara di Kabupaten Pulang Pisau tercatat sekitar 3.582 ha, yang sebarannya dapat dilihat pada Gambar 15a dan 15b.

Dengan mengacu pada SK Menteri Kehutanan No. 529/Menhut-II/2012 tentang penunjukan kawasan hutan, dari luas total 43.784 ha perkebunan kelapa sawit rakyat di Kabupaten Kotawaringin Barat, sekitar 23\% nya atau 10.133 ha berada di dalam kawasan hutan dengan berbagai fungsi (Tabel 3).

Dari total luasan 3.582 ha perkebunan kelapa sawit rakyat di Kabupaten Pulang Pisau, hanya 19\% saja yang terindikasi berada dalam kawasan hutan (Tabel 4).

Berdasarkan wawancara dengan berbagai pihak dan pengamatan lapangan, keberadaan perkebunan kelapa sawit dalam kawasan hutan tidak terlepas penyebab ketimpangan penguasaan dominan oleh korporasi sepanjang mata rantai produksi dan pengolahan produk minyak sawit dari mulai hulu hingga hiilir. Perambahan perkebunan kelapa sawit ke dalam kawasan hutan terjadi karena masyarakat termotivasi untuk memanfaatkan areal-areal yang mereka anggap open access, tidak ada yang menguasai, dan karena ketidaktahuan mereka terhadap batas kawasan hutan. 

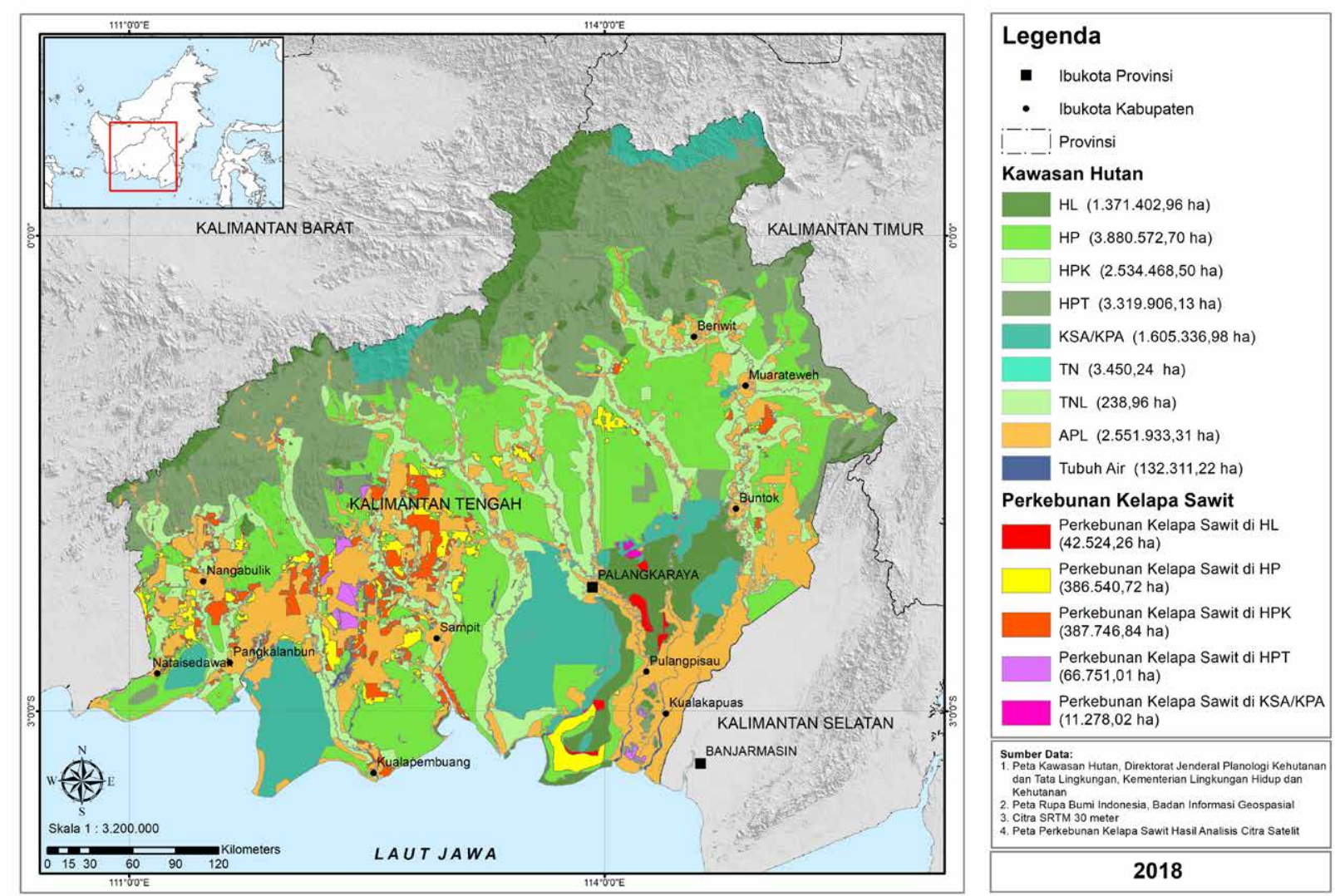

Gambar 13. Peta perkebunan kelapa sawit dalam kawasan hutan di Provinsi Kalimantan Tengah

Sumber: Analisis spasial (2018)
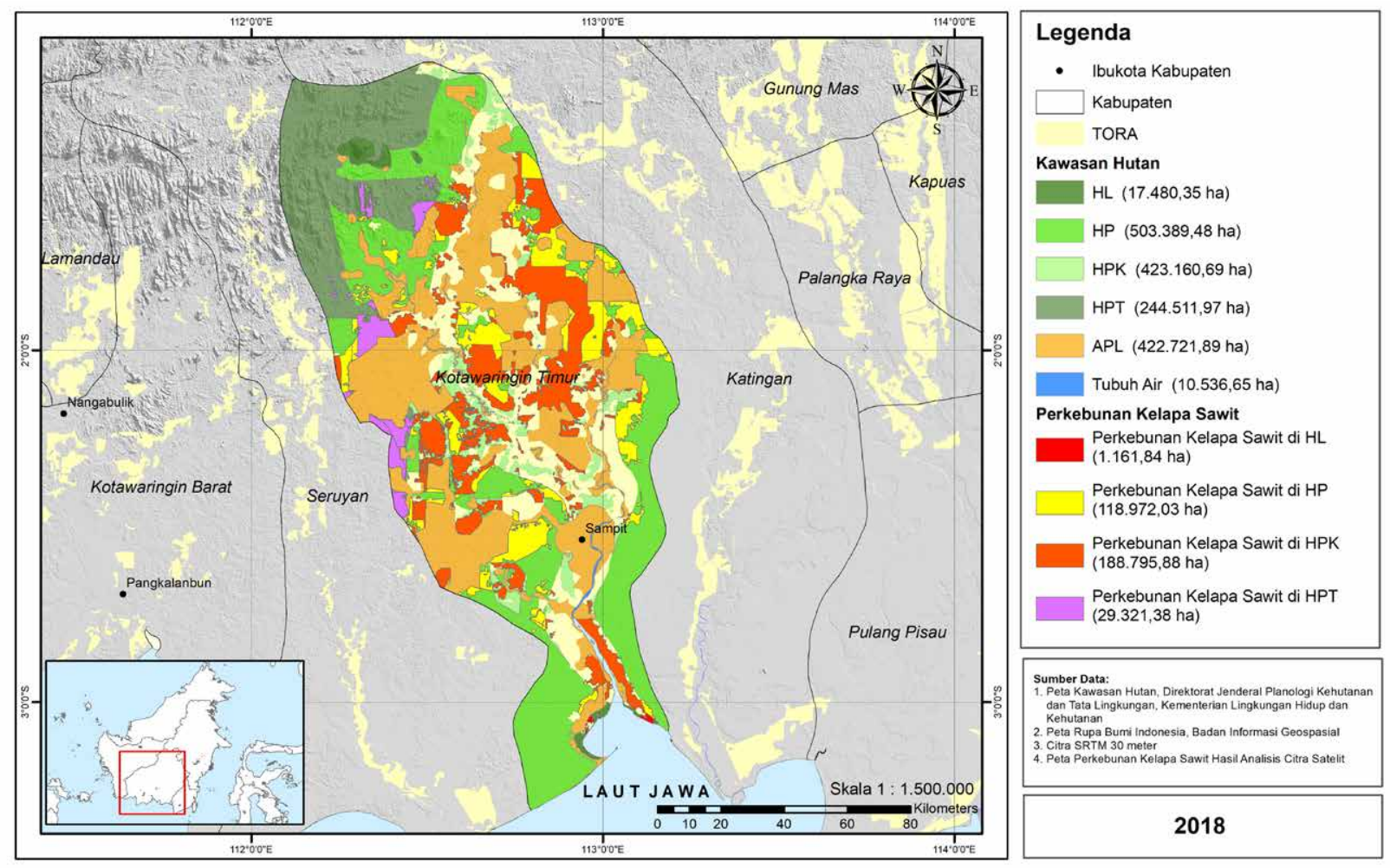

Gambar 14. Peta perkebunan kelapa sawit dalam kawasan hutan dan TORA Kabupaten Kotawaringin Timur Provinsi Kalimantan Tengah

Sumber: Analisis spasial (2018) 

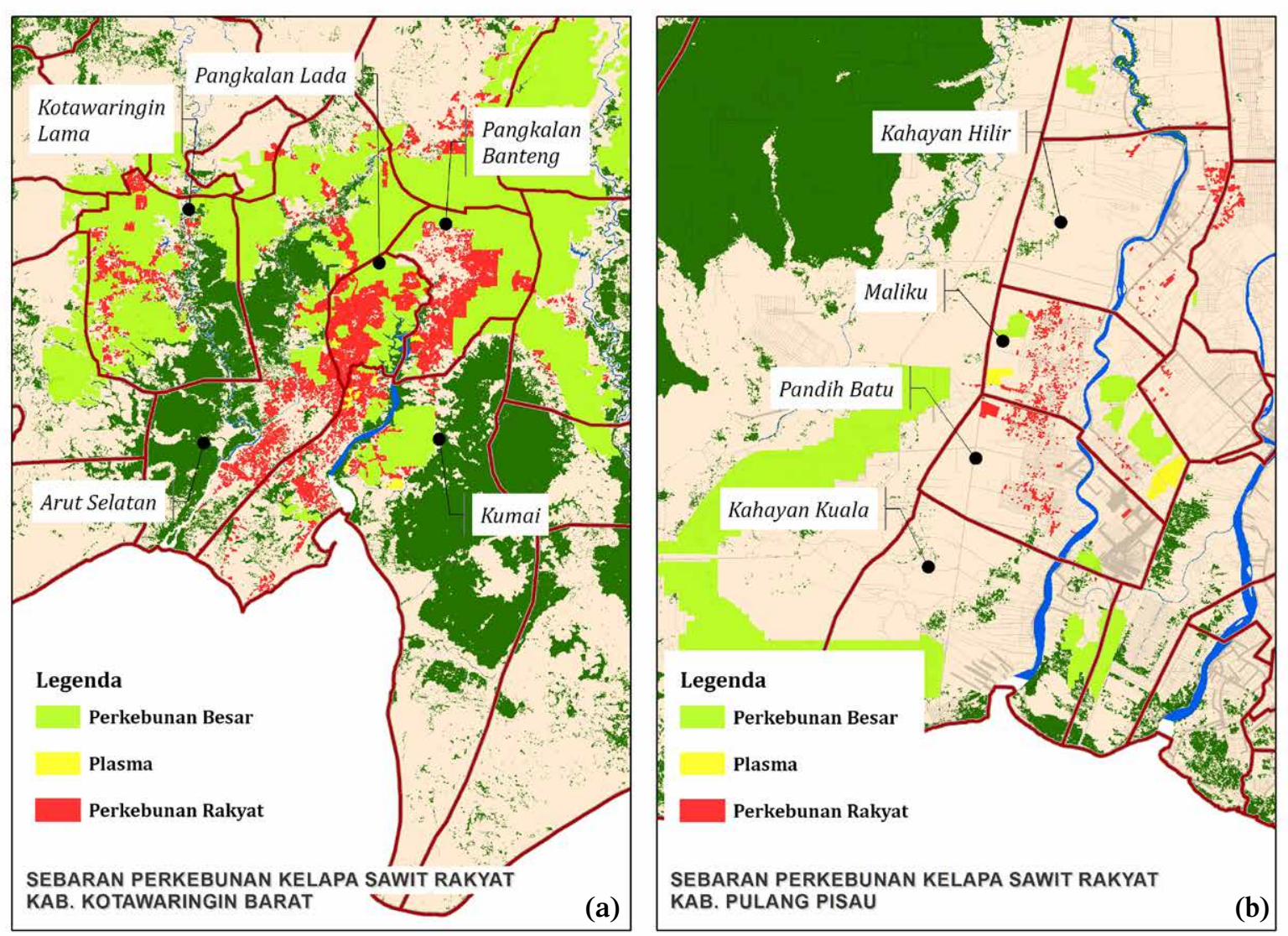

Gambar 15. Sebaran perkebunan kelapa sawit rakyat di Kabupaten (a) Kotawaringin Barat dan (b) Pulang Pisau

Sumber: Analisis spasial (2018)

Tabel 3. Luas perkebunan kelapa sawit rakyat di Kabupaten Kotawaringin Barat

\begin{tabular}{lc}
\hline Kawasan Hutan & Luas kebun sawit rakyat (ha) \\
\hline Hutan Produksi Konversi (HPK) & 6.590 \\
Hutan Produksi (HP) & 3.529 \\
Taman wisata alam & 14 \\
Total kawasan hutan & $\mathbf{1 0 . 1 3 3}$ \\
Areal Penggunaan Lain (APL) & 33.651 \\
Total kawasan hutan dan APL & $\mathbf{4 3 . 7 8 4}$ \\
\hline
\end{tabular}

Sumber: Analisis spasial (2018)

Tabel 4. Luas perkebunan kelapa sawit rakyat di Kabupaten Pulang Pisau

\begin{tabular}{lcr}
\hline Kawasan Hutan & Luas kebun sawit rakyat (ha) & \% \\
\hline Hutan Produksi Terbatas (HPT) & 9 & 0.25 \\
Hutan Produksi (HP) & 533 & 14.88 \\
Hutan Lindung (HL) & 153 & 4.27 \\
Areal Penggunaan Lain (APL) & 2,887 & 80.60 \\
Total & $\mathbf{3 , 5 8 2}$ &
\end{tabular}

Sumber: Analisis spasial (2018) 
Terjadinya tumpang tindih juga disebabkan oleh proses paduserasi tata ruang yang belum selesai, terutama penetapan kawasan hutan di dalam tata ruang daerah. Sebagai contoh, areal yang pada awalnya berdasarkan RTRWP/RTRWK ditetapkan sebagai Kawasan Pengembangan Produksi (KPP) atau Kawasan Pemukiman dan Penggunaan Lain (KPPL) - yang statusnya dengan Areal Penggunaan Lain (APL) - kemudian dengan keluarnya peraturan Menteri Kehutanan (Permenhut No 529/2012), areal tersebut dinyatakan sebagai kawasan hutan, baik fungsi hutan produksi atau hutan produksi terbatas. Akibatnya banyak perkebunan kelapa sawit yang terlanjur sudah dibangun di areal APL berada di dalam kawasan hutan.

Terjadinya tumpang tindih perkebunan kelapa sawit di kawasan hutan tersebut menambah gambaran tingginya kompleksitas konflik tenurial di Kalimantan Tengah. Misalnya, sepanjang tahun 2011 terjadi 40 kasus sengketa tenurial di provinsi ini (WALHI, 2017). Kasus sengketa yang terjadi terkait dengan persoalan tata kuasa yakni dalam bentuk HGU yang cacat hukum dan sengketa tata guna yang terjadi antara perkebunan dengan kehutanan dan peruntukan lain. 


\section{Perkembangan perkebunan kelapa sawit dan permasalahan tenurial di Kalimantan Barat}

\subsection{Perkembangan perkebunan kelapa sawit di Kalimantan Barat}

Peraturan Daerah tentang Tata Ruang Wilayah Provinsi Kalimantan Barat dan SK Menteri Kehutanan No. 733/2014 tentang Penunjukkan Kawasan Hutan dan Perairan di Provinsi Kalimantan Barat menunjukkan bahwa wilayah provinsi mencapai 14.73 juta ha, yang terdiri dari kawasan hutan 8,31 juta ha dan APL 6,42 juta ha. Sesuai rencana umum perkebunan, ditargetkan luas perkebunan kelapa sawit adalah 4 juta ha yang akan dicapai dalam kurun waktu 2014-2034 (Dinas Perkebunan Provinsi Kalimantan Barat, 2017). Perkembangan perkebunan kelapa sawit yang pesat di provinsi ini bukan proses yang singkat, tetapi telah melalui sejarah yang panjang. Peran pengusaha kolonial sangat penting untuk ditelusuri jejak-jejaknya. Pada sekitar 1920-an, pemerintah kolonial mendirikan perkebunan karet di Kalimantan Barat dan Kalimantan Selatan. Setelah mengenal lama sistem budidaya karet, masyarakat menjadi tidak begitu asing lagi ketika sistem perkebunan kelapa sawit dikenalkan (Setra, 2013). Sejarah penanaman kelapa sawit di provinsi ini juga tidak dapat dilepaskan dari peran penting PT. Perkebunan Nasional (PTPN XIII) yang pada tahun 1980an diberikan tanggung jawab oleh pemerintah untuk membuka lahan kelapa sawit melalui pola kerja sama dengan masyarakat. Salah satu kriteria yang ditetapkan oleh pemerintah provinsi adalah bahwa perkebunan kelapa sawit harus dibangun di wilayah kabupaten yang memiliki luas lahan minimal 8.000 ha dan berada dalam satu hamparan wilayah. Angka ini juga menjadi syarat pemerintah pusat untuk pembukaan lahan perkebunan kelapa sawit. Salah satu kabupaten yang memenuhi syarat minimal luas tersebut adalah Landak. Perkebunan kelapa sawit berkembang pada awalnya di Kecamatan Ngabang, Kabupaten Landak, dan di Kecamatan Parindu, Kecamatan Kembayan, Kecamatan Meliyau, Kabupaten Sanggau (Setra, 2013).

Syarat tentang batasan luasan tersebut tidak berlaku di Kabupaten Kapuas. Pada awal tahun 1980an, PTPN XIII diberi izin menyewa lahan pemerintah seluas 5.700 ha untuk membangun perkebunan kelapa sawit di tepi utara Sungai Kapuas. Konsesi ini termasuk tanah bekas NV Kapoewas/Agris yang mulai digunakan petani (Semedi \& Bakker, 2014). Seiring dengan semakin berkurangnya hutan primer, intensitas kegiatan penebangan kayu berkurang pada pertengahan tahun 1990an. Para pengusaha penebangan kayu melakukan ekspansi ke daerah baru dan membuka hutan untuk kemudian dibangun perkebunan kelapa sawit. Pada tahun 2010, tercatat ada 326 perusahaan kelapa sawit dengan luasan areal mencapai 4,8 juta ha atau sekitar sepertiga wilayah Kalimantan Barat (Setra, 2013).

Bagi para petani ini, pertemuan mereka dengan perusahaan perkebunan kelapa sawit penuh dengan cerita yang menantang. Masyarakat banyak yang kehilangan lahan dan tanaman akibat alih penguasaan lahan untuk perkebunan skala besar. Tuntutan masyarakat untuk memperoleh kompensasi atas hilangnya lahan umumnya ditolak pihak perusahaan dengan alasan bahwa masyarakat secara ilegal menduduki lahan negara. Setelah kehilangan alat produksi utama, banyak petani menjadi miskin, dan sebagian menjadi buruh perkebunan. Sementara, sebagian penduduk melintasi perbatasan dan bermigrasi ke Malaysia, dan sebagian lainnya pergi ke wilayah kota di Sanggau dan Pontianak untuk bekerja dan mencari nafkah. Satu dekade kemudian, dua perusahaan swasta, PT. Harapan Dharma dan PT. Sawit Permata berinvestasi di Kabupaten Kapuas. Perusahaan-perusahaan ini telah memperoleh izin untuk mengusahakan areal konsesi perkebunan seluas 38.810 ha, yakni masing-masing PT Harapan Dharma seluas 18.576 ha dan PT Sawit Permata 20.234 ha melalui skema perkebunan inti plasma (Semedi \& Bakker, 2014). 
Sampai 2016, luas areal perkebunan kelapa sawit di Provinsi Kalimantan mencapai 1.439.815 ha (Gambar 16), yang terdiri dari tanaman muda seluas 582.302 ha, tanaman menghasilkan 844.492 ha, dan tanaman tua/rusak 13.021 ha. Jumlah produksi kelapa sawit pada tahun 2016 sebesar 2.001.943 ton. ${ }^{11}$ Perkebunan kelapa sawit di provinsi ini hampir mencapai $12 \%$ dari luas perkebunan kelapa sawit nasional (11,7 juta ha) dengan luasan perkebunan petani swadaya mencapai 300.000 ha.

Seperti yang terjadi di Provinsi Kalimantan Tengah, struktur penguasaan perkebunan kelapa sawit juga terjadi ketimpangan, baik dalam hal luasan maupun produksi. Penguasaan perkebunan kelapa sawit di Provinsi Kalimantan Barat dikuasai sebagian besar oleh pihak perusahaan atau korporasi (Gambar 17).

\subsection{Peta konflik tenurial perkebunan kelapa sawit}

Peta konflik terkait sektor perkebunan di Kalimantan Barat menyerupai dengan kasus-kasus yang terjadi di Kalimantan Tengah yakni terkait dengan persoalan tata kuasa, tata guna dan tata usaha. Konflik terjadi dalam bentuk perorangan yakni berupa tuntutan individu masyarakat atas pengembalian kepemilikan tanah. Konflik juga terjadi antara perusahaan dengan kelompok masyarakat yang menuntut pengembalian tanah adat, ganti rugi tanam tumbuh dan tanah garapan, ganti rugi yang belum dibayarkan, perbaikan kerusakan lingkungan dan fasilitas umum serta tuntutan untuk dibangunkannya tanaman plasma. Konflik lainnya terjadi antar badan hukum, misalnya tumpang tindih penguasaan lahan antara perusahaan perkebunan dengan pertambangan, yang seringkali disebabkan tidak jelasnya peruntukan lahan dan batas wilayah. ${ }^{12}$

Dalam tiga tahun terakhir, konflik antara masyarakat dengan perusahaan perkebunan cenderung mengalami peningkatan di Kalimantan Barat. Pada tahun 2014, misalnya, Koalisi Masyarakat Sipil Kalimantan Barat (2015) mencatat setidaknya 57 komunitas masyarakat berkonflik dengan perusahaan perkebunan kelapa sawit. Kepolisian Daerah Kalimantan Barat mempublikasikan angka kasus konflik yang lebih tinggi pada tahun yang sama, yakni 101 konflik (Koalisi Masyarakat Sipil Kalimantan Barat, 2015). Pada tahun 2016, jumlah kasus konflik terkait usaha perkebunan meningkat menjadi 104 kasus (Badan Pertanahan Nasional Provinsi Kalimantan Barat, 2017).

Perkebunan perusahaan kelapa sawit yang terindikasi di dalam kawasan hutan di Provinsi Kalimantan Barat mencakup luasan 88.238 ha (Gambar 18). ${ }^{13}$ Sebagian besar dari perkebunan tersebut berada di hutan produksi $(53,7 \%)$ dan hutan produksi terbatas $(30,3 \%)$. Sebagian perkebunan lainnya dalam proporsi kecil berada di hutan lindung, hutan produksi terbatas dan kawasan konservasi. Menurut AURIGA (2017), sebagian perkebunan kelapa sawit yang sudah dibebani HGU diketahui berada pada kawasan dengan fungsi hutan produksi terbatas dengan luasan mencapai 1.205,43 ha dan hutan produksi seluas 7.168,62 ha. Sebagian perkebunan kelapa sawit diduga juga tumpang tindih dengan areal hutan tanaman industri seluas 930,21 ha, hutan lindung seluas 829,23 ha dan bahkan dengan hutan konservasi seluas 55,36 ha.

Di Kabupaten Landak diketahui terdapat 1.828 ha perkebunan yang berada di dalam kawasan hutan (Gambar 19), yang sebagian besar berada pada hutan produksi $(87,6 \%)$ dan hutan produksi terbatas $(11,5 \%)$. Di kabupaten ini teridentifikasi juga perkebunan yang berada di atas hutan lindung, sekalipun arealnya kecil. Tidak tercatat adanya perkebunan kelapa sawit di hutan produksi terbatas.

11 Menurut Kepala Dinas Perkebunan Provinsi Kalimantan Barat (2017)

12 Berdasarkan pemaparan nara sumber dari Badan Pertanahan Nasional wilayah Kalimantan Barat dalam acara FGD tentang beragam bentuk konflik terkait perkebunan kelapa sawit.

13 Kementerian Lingkungan Hidup dan Kehutanan menyatakan bahwa beberapa lahan ilegal diantaranya di Kalimantan Barat seluas 800 ribu ha (Warta Ekonomi 6 Januari 2017). 


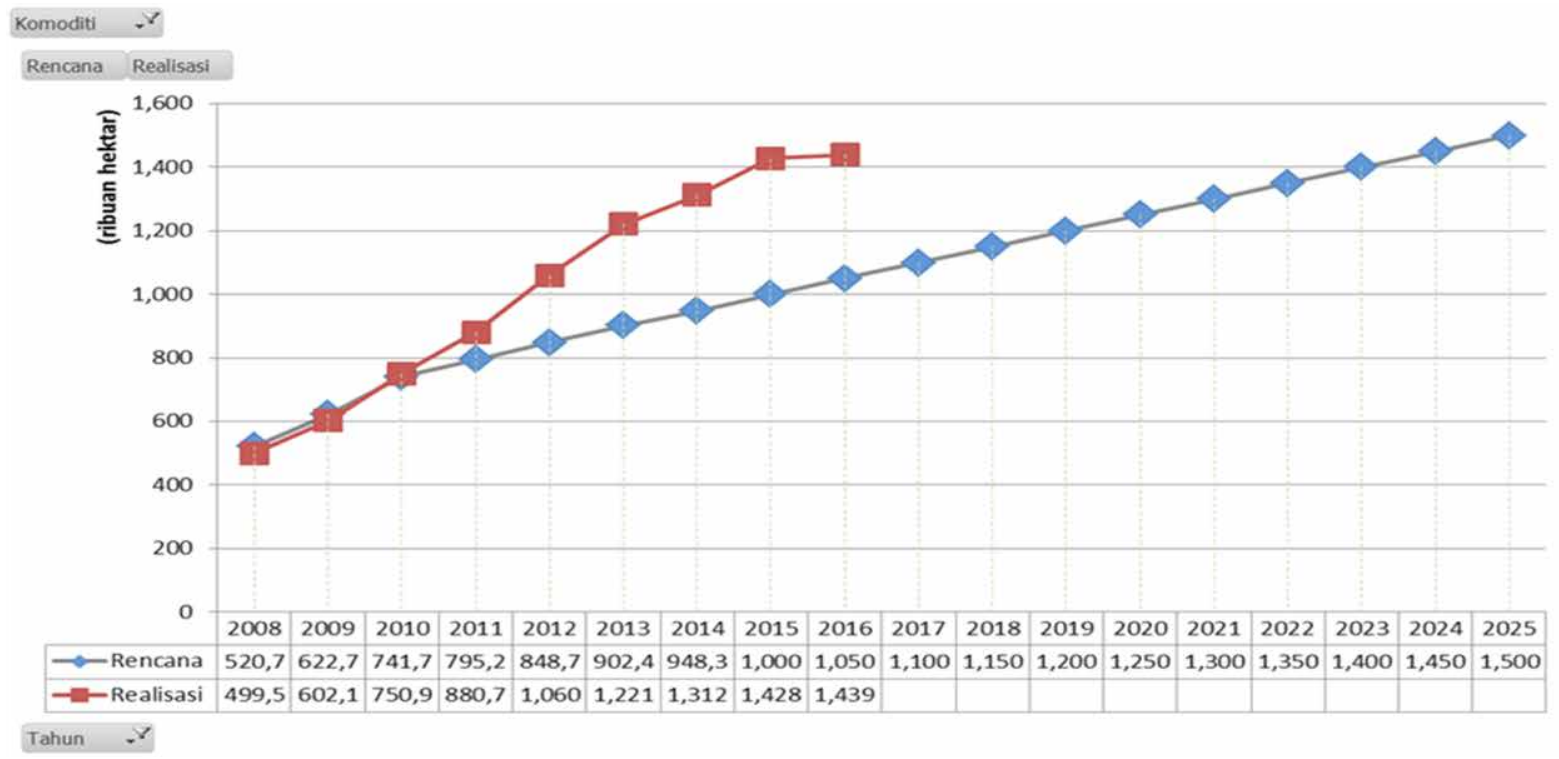

Gambar 16. Rencana dan realisasi pembangunan perkebunan kelapa sawit antara tahun 2008 sampai 2025 di Provinsi Kalimantan Barat

Sumber: Dinas Perkebunan Kalimantan Barat (2017)

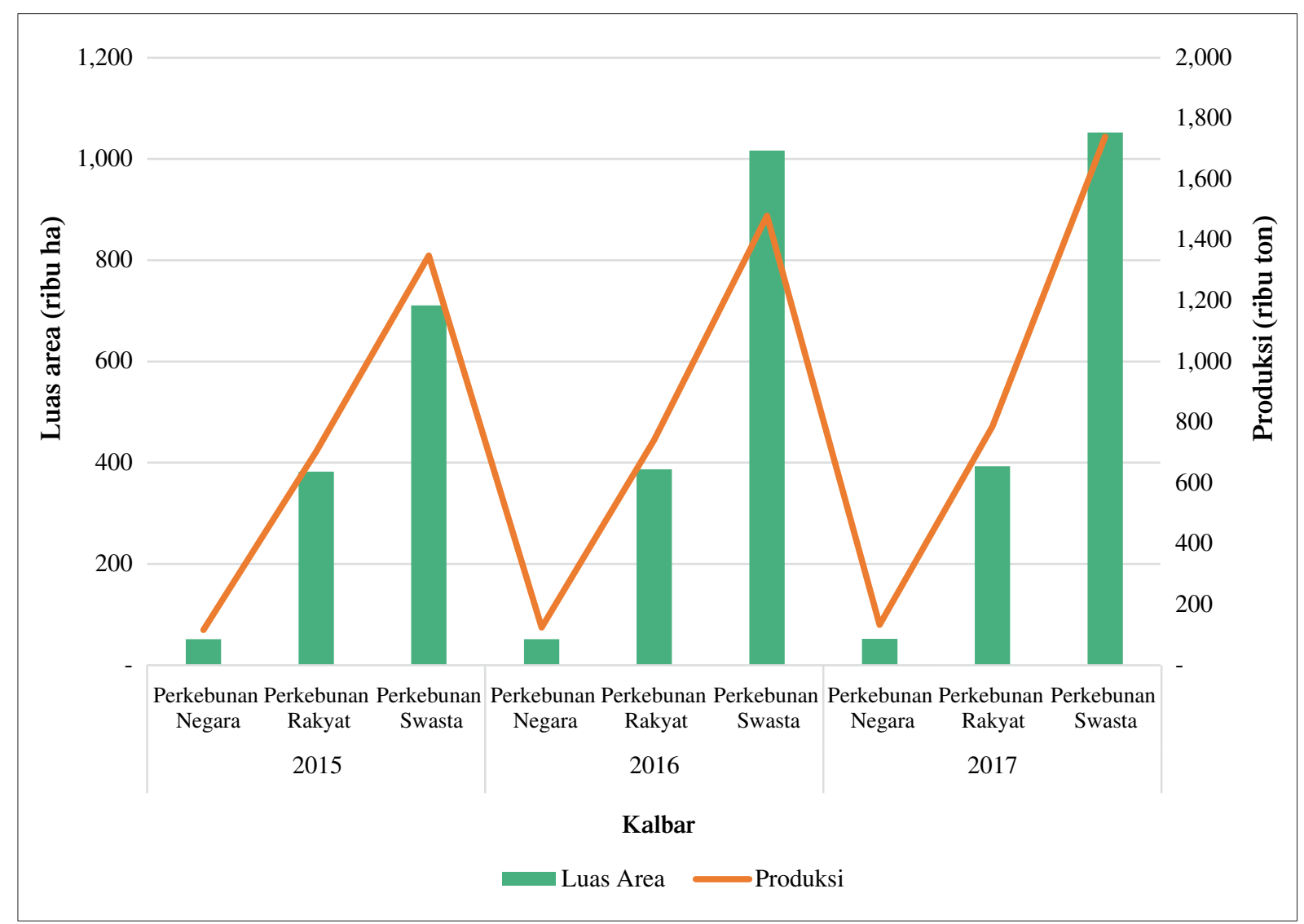

Gambar 17. Perkembangan luas dan produksi perkebunan kelapa sawit yang dikelola oleh perusahaan negara, swasta dan rakyat dari tahun 2015 sampai 2017 di Provinsi Kalimantan Barat

Sumber: Statistik Perkebunan 2017 (data diolah) 


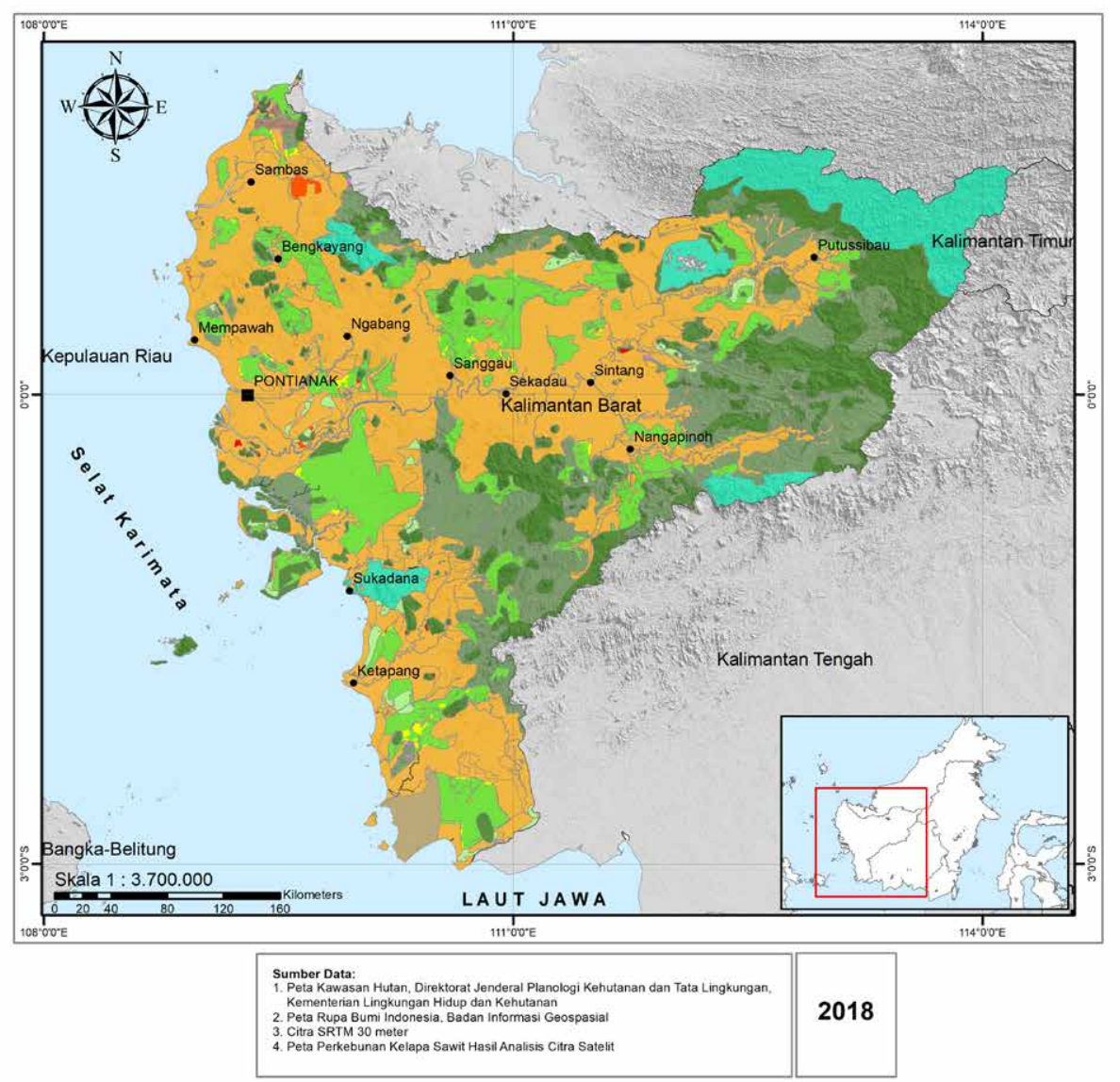

\begin{tabular}{|c|c|}
\hline \multicolumn{2}{|c|}{ Legenda } \\
\hline & Ibukota Kabupaten \\
\hline & Ibukota Provinsi \\
\hline & Provinsi \\
\hline \multicolumn{2}{|c|}{ Kawasan Hutan } \\
\hline & HL (2.295.082,59 ha) \\
\hline & HP $(2.125 .662,56$ ha) \\
\hline & HPK (197.732,32 ha) \\
\hline & HPT (2.124.018,01 ha) \\
\hline & KSA/KPA $(848,62$ ha) \\
\hline & TN (1.229.886,26 ha) \\
\hline & TNL (4.170,98 ha) \\
\hline & TWA (31.700,53 ha) \\
\hline & CA $(153.771,38 \mathrm{ha})$ \\
\hline & APL $(6.378 .113,32$ ha) \\
\hline & Tubuh Air ( $83.781,35$ ha) \\
\hline & $\begin{array}{l}\text { Junan Kelapa Sawit } \\
\text { Perkebunan Kelapa Sawit di HL } \\
(6.749,65 \text { ha) }\end{array}$ \\
\hline & $\begin{array}{l}\text { Perkebunan Kelapa Sawit di HP } \\
\text { ( } 47.374,58 \text { ha) }\end{array}$ \\
\hline & $\begin{array}{l}\text { Perkebunan Kelapa Sawit di HPK } \\
\text { (26.694,94 ha) }\end{array}$ \\
\hline & $\begin{array}{l}\text { Perkebunan Kelapa Sawit di HPT } \\
(6,161,15 \text { ha) }\end{array}$ \\
\hline & $\begin{array}{l}\text { Perkebunan Kelapa Sawit di CA } \\
(21,38 \mathrm{ha})\end{array}$ \\
\hline & $\begin{array}{l}\text { Perkebunan Kelapa Sawit di TN } \\
(47,20 \text { ha) }\end{array}$ \\
\hline & $\begin{array}{l}\text { Perkebunan Kelapa Sawit di TWA } \\
(1.189,22 \text { ha) }\end{array}$ \\
\hline
\end{tabular}

Gambar 18. Peta perkebunan kelapa sawit dalam kawasan hutan di Provinsi Kalimantan Barat Sumber: Analisis spasial (2018)
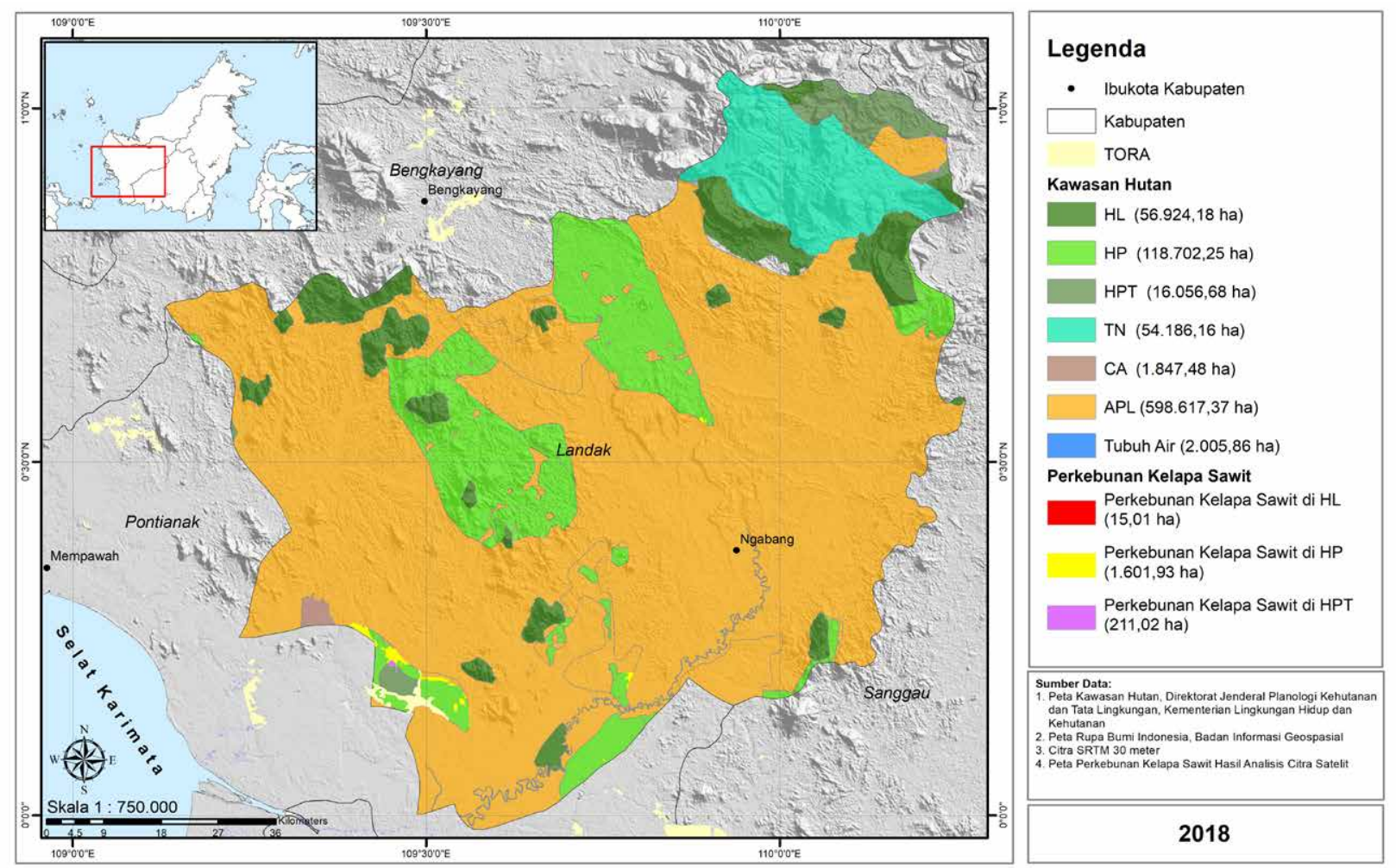

Gambar 19. Peta perkebunan kelapa sawit dalam kawasan hutan dan TORA di Kabupaten Landak, Provinsi Kalimantan Barat

Sumber: Analisis spasial (2018) 
Terjadinya tumpang tindih perkebunan dengan kawasan hutan di Kabupaten Landak diakui karena adanya perubahan kebijakan tata ruang dan kawasan hutan. Salah satu kasus menunjukkan adanya areal kebun seluas 200 ha yang menurut SK Menhut No. 259/2000 ${ }^{14}$ termasuk kawasan hutan. Dengan keluarnya SK Menhut No. 733/2014, ${ }^{15}$ areal tersebut ternyata kemudian dinyatakan masuk dalam kawasan hutan dengan fungsi hutan produksi konversi, sehingga harus dikeluarkan melalui proses pelepasan. Namun, ketika proses pelepasan berlangsung, diketahui bahwa ternyata tutupan areal tersebut berupa kebun tua, dan kawasannya belum ditata batas. Pihak pemerintah daerah menganggap kebijakan pemerintah pusat sering diberlakukan tanpa terlebih dahulu ada konsultasi. Diakui bahwa SK 733/2014 diberlakukan tanpa adanya proses audiensi atau konsultasi terlebih dahulu dengan pihak daerah, terutama pemerintah kabupaten, sehingga terkesan kebijakan datang secara tiba-tiba. ${ }^{16}$

Terkait dengan keberadaan perkebunan kelapa sawit di kawasan hutan, pihak Inspektorat Jenderal Kementerian Lingkungan Hidup dan Kehutanan sebenarnya pernah melakuan inspeksi, namun demikian hasil dari pemeriksaan tersebut belum diketahui hasilnya. ${ }^{17}$

Selain perkebunan perusahaan, areal perkebunan kelapa sawit rakyat juga diduga tumpang tindih dengan kawasan hutan di kabupaten lainnya, Sanggau, Sintang dan Kapuas Hulu, sekalipun luasannya kecil. Dengan mengacu pada SK 733/2014, perkebunan rakyat di ketiga kabupaten tersebut sebagian besar (98\%) atau sekitar 4.077 ha berada di APL, dan hanya sekitar 2\% saja atau 79 ha areal kebun sawit rakyat yang berada di dalam kawasan hutan.

14 Keputusan Menteri Kehutanan No. 259/Kpts-II/2000 tentang Penunjukan Kawasan Hutan dan Perairan di Wilayah Provinsi Kalimantan Barat seluas 9.178.760 ha

15 Keputusan Menteri Kehutanan No. 733/Menhut-II/2014 tentang Kawasan Hutan dan Konservasi Perairan Provinsi Kalimantan Barat

16 Hasil wawancara dengan Kepala Dinas Perkebunan Kabupaten Landak

17 Wawancara dengan staf BPKH Kalimantan Barat (2017) 


\section{Bagaimana pandangan para pihak terhadap perkebunan kelapa sawit di dalam kawasan hutan?}

Berdasarkan data primer penelitian, diketahui bahwa hampir lebih dari setengah dari responden (53\%) berpandangan bahwa perkebunan kelapa sawit yang berada di dalam kawasan hutan merugikan negara. Sekitar 27,7\% responden menyatakan kurang setuju dan 19,3\% responden menyatakan tidak setuju dengan pendapat tersebut. Pendapat yang mengaitkan keberadaan perkebunan kelapa sawit di dalam kawasan hutan dengan kerugian negara didasarkan pada pertimbangkan hilangnya pendapatan negara akibat tidak tercatatnya penggunaan kawasan hutan. Dari kajian Direktorat Jenderal Planologi Kehutanan dan Tata Lingkungan (2016), diperoleh taksiran kerugian yang dihitung dari asumsi perhitungan nilai sewa izin pinjam pakai yang nilainya Rp 1 juta/ha/bulan. Dengan asumsi luas total areal perkebunan di kawasan hutan mencapai 2,3 juta ha, maka taksiran kerugian mencapai Rp 27,6 triliun setiap tahun atau Rp 2,3 triliun setiap bulannya.

Dari hasil survey juga diketahui para pihak berpandangan bahwa perkebunan kelapa sawit berperan sebagai salah satu pemicu terjadinay deforestasi. Sebagian besar responden yakni 61,6\% dari sampel menyampaikan persetujuannya bahwa perkebunan kelapa sawit menjadi salah satu penyebab deforestasi, sementara sisanya sekitar $29,1 \%$ menyatakan pandangan kurang setuju $(29,1 \%)$ dan sebagian lain $(9.3 \%)$ menyatakan pandangan tidak setuju. 


\section{Kebijakan penyelesaian penguasaan perkebunan kelapa sawit dalam kawasan hutan}

Beberapa kebijakan sudah dikeluarkan sebagai upaya untuk mengatur alokasi lahan perkebunan yang berasal dari kawasan hutan dan untuk mengatasi kasus-kasus keterlanjuran perkebunan kelapa sawit, baik yang dikuasai oleh perusahaan maupun oleh masyarakat, yang berada di dalam kawasan hutan. Beberapa opsi penyelesaian antara lain pelepasan kawasan hutan, tukar menukar kawasan hutan, perhutanan sosial, reforma agraria dan penegakan hukum (Gambar 20). Pelepasan dan tukar menukar kawasan hutan yang diatur di dalam Peraturan Pemerintah No. 10/2010 dan beberapa peraturan perubahannya merupakan mekanisme untuk menyelesaian kasus-kasus penguasaan tanah di dalam kawasan hutan, terutama yang melibatkan perusahaan. Penyelesaian kasus-kasus penguasaan tanah oleh masyarakat mengacu pada Peraturan Presiden No. 88/2017 tentang penyelesaian penguasaan tanah dalam kawasan hutan.
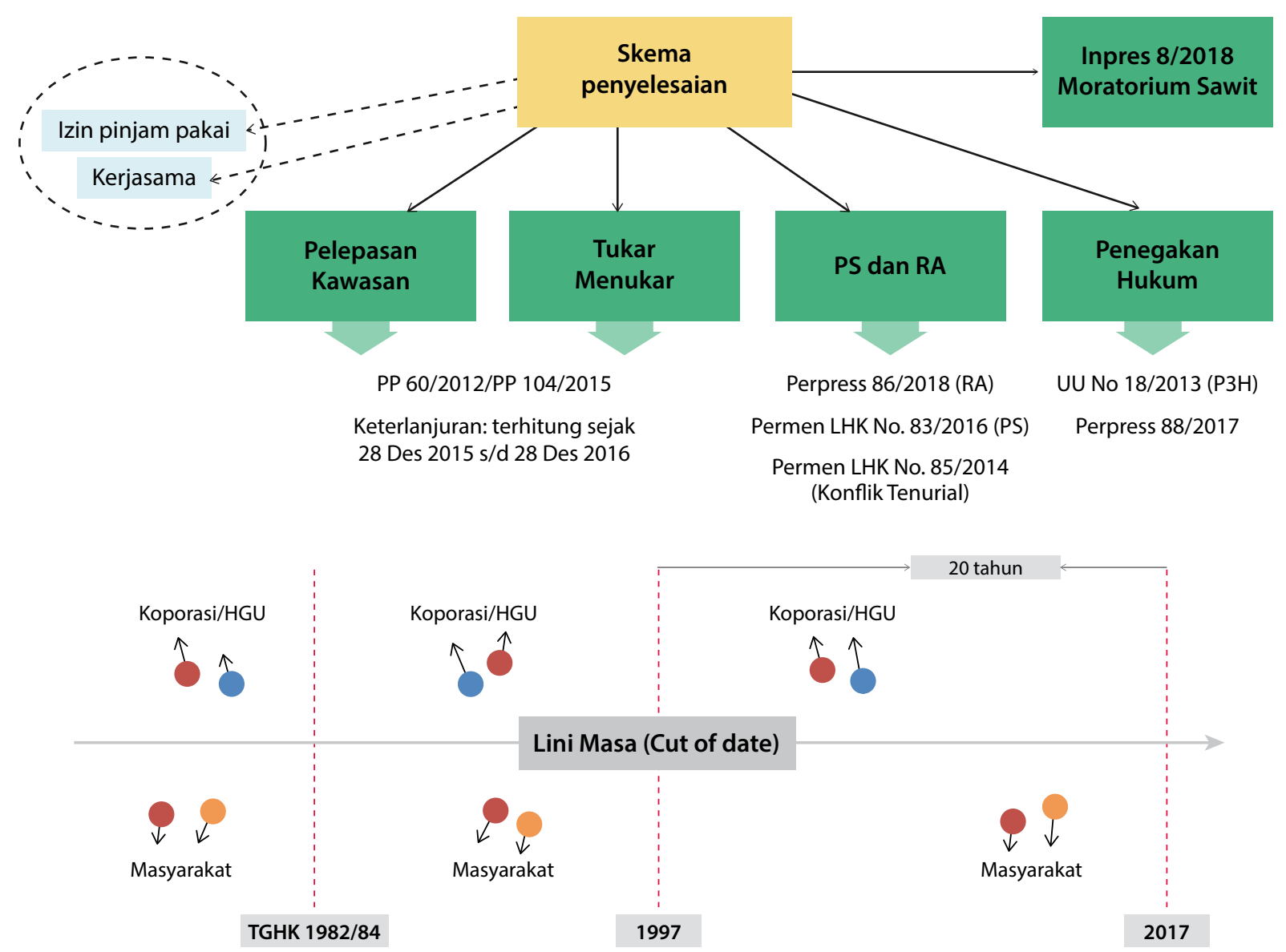

Gambar 20. Skema penyelesaian penguasaan lahan di kawasan hutan 


\subsection{Pelepasan dan tukar menukar kawasan hutan}

Untuk memenuhi kepentingan pembangunan di luar kegiatan kehutanan, kawasan hutan dapat diubah peruntukannya baik secara parsial maupun untuk wilayah provinsi, seperti diatur di dalam Peraturan Pemerintah No. 10/2010. ${ }^{18}$ Perubahan peruntukan secara parsial dapat dilakukan melalui tukar menukar dan pelepasan kawasan hutan. Yang dimaksud dengan tukar menukar kawasan hutan adalah perubahan kawasan hutan produksi tetap dan/atau hutan produksi terbatas menjadi bukan kawasan hutan yang diimbangi dengan memasukkan lahan pengganti dari bukan kawasan hutan menjadi kawasan hutan. Pelepasan kawasan hutan adalah perubahan peruntukan kawasan hutan produksi yang dapat dikonversi menjadi bukan kawasan hutan.

Kawasan hutan dapat diubah peruntukannya menjadi bukan kawasan hutan hanya jika berada pada kawasan dengan fungsi hutan produksi yang dapat dikonversi dan pada provinsi yang luas kawasan hutannya kurang dari $30 \%$. Hutan yang akan dilepas bisa dalam keadaan berhutan maupun tidak berhutan.

Dalam perkembangannya, banyak terjadi perubahan peruntukan dan fungsi kawasan hutan seiring dengan penyusunan rencana tata ruang wilayah provinsi dan kabupaten/kota, terutama setelah ditetapkannya UU No 26/2007 tentang Penataan Ruang. Hal ini telah mengakibatkan adanya perbedaan peruntukan ruang antara yang tertuang di dalam rencana tata ruang wilayah dengan peruntukan dan fungsi kawasan hutan, seperti yang terjadi di Provinsi Kalimantan Tengah. Dalam mengantisipasi ketidakpastian pemanfaatan ruang dan iklim investasi, pemerintah kemudian mengeluarkan Peraturan Pemerintah No. 60/2012 yang intinya memberikan kesempatan kepada pelaku usaha, yang areal usaha perkebunannya berada di dalam kawasan hutan, untuk mengajukan permohonan pelepasan kawasan hutan dan tukar menukar. Proses pelepasan kawasan hutan ditempuh jika lokasi perkebunan berada pada kawasan hutan dengan fungsi HPK, dan proses tukar menukar harus ditempuh jika lokasi perkebunannya berada pada kawasan hutan dengan fungsi HP atau HPT.

Sekalipun proses perubahan peruntukan kawasan hutan sudah cukup lengkap diatur dalam peraturan perundangan tersebut, ternyata dalam perkembangannya banyak masalah yang belum bisa diatasi seiring dengan meningkatnya tuntutan kebutuhan akan lahan dari luar sektor kehutanan. Dengan keluarnya keputusan Mahkamah Konstitusi No. 45/2011, penentuan kawasan hutan tidak lagi didasarkan pada penunjukan kawasan hutan, tetapi harus melalui tahap-tahap penataan batas, pemetaan dan penetapan kawasan hutan. Dalam menghadapi hal tersebut, pemerintah kemudian mengeluarkan Peraturan Pemerintah No. 104/2015 yang intinya sama berisi ketentuan tentang prosedur dan syaratsyarat perubahan peruntukan kawasan dengan peraturan perundangan-undangan sebelumnya, namun menekankan bahwa hutan produksi yang dapat dikonversi adalah yang tidak produktif.

Peraturan Pemerintah No. 104/2015 dimaksudkan untuk menyelesaikan kasus-kasus perizinan perkebunan kelapa sawit yang terlanjur diberikan oleh pemerintah daerah dan berada dalam kawasan hutan. Pada Pasal 51 disebutkan bahwa investor diberi kesempatan untuk mengajukan permohonan pelepasan kawasan hutan atau tukar menukar jika, berdasarkan peta kawasan hutan terakhir, areal perkebunan mereka berada pada hutan produksi yang dapat dikonversi, hutan produksi tetap atau hutan produksi terbatas. Menurut ketentuan tersebut, tenggat waktu yang diberikan adalah satu tahun sejak berlakunya peraturan pemerintah tersebut yakni sejak 28 Desember 2015 sampai 28 Desember 2016. Jika perkebunan mereka menurut peta kawasan hutan terakhir berada dalam kawasan hutan dengan fungsi konservasi dan/atau lindung, maka investor diberikan kesempatan untuk melanjutkan usaha perkebunannya pada areal tersebut selama satu daur tanaman pokok.

Tata cara pelepasan kawasan hutan lebih lanjut diatur dalam Peraturan Menteri Lingkungan Hidup dan Kehutanan No. 51/2016. Prinsip pelepasan kawasan hutan adalah bahwa kawasan hutan yang dilepaskan berada pada fungsi hutan produksi yang dapat dikonversi, dan memenuhi kriteria antara

18 tentang Tata Cara Perubahan Peruntukan dan Fungsi Kawasan Hutan 
lain: tidak dibebani izin penggunaan dan pemanfaatan lain, tidak produktif dan berada pada provinsi yang luas kawasannnya di atas 30\% serta tidak berada dalam peta izin indikatif penundaan pemberian izin baru (PIPIB). Menurut ketentuan dalam peraturan menteri tersebut, luas perkebunan kelapa sawit dari kawasan hutan yang dilepaskan tersebut paling banyak 60.000 ha untuk satu perusahaan atau grup perusahaan dengan ketentuan izin diberikan secara bertahap dengan luasan maksimal 20.000 ha dan proses pelepasan kawasan berikutnya dilaksanakan setelah ada evaluasi sejauh mana kawasan yang sebelumnya dilepaskan telah dimanfaatkan sesuai dengan izin usaha yang diajukan. Evaluasi juga dilakukan terhadap sejauh mana kewajiban untuk menyediakan seluas $20 \%$ dari total luas kawasan hutan yang dilepaskan untuk kebun masyarakat telah terpenuhi, dan apakah perkebunan yang dibangun telah mencapai minimal 50\% dari kawasan hutan yang dilepaskan sebelumnya.

Tukar menukar kawasan hutan dilakukan untuk memenuhi kebutuhan pembangunan di luar kegiatan kehutanan yang bersifat permanen, seperti diatur di dalam Peraturan Menteri Kehutanan No. P.32/2010, dan dua peraturan menteri lainnya yakni No. P.41/2012 dan No. P.27/2014 yang mengubah beberapa ketentuan. Perkebunan kelapa sawit dikategorikan dalam peraturan menteri tersebut sebagai salah satu bentuk kegiatan untuk kepentingan umum.

Penyelesaian tumpang tindih kawasan hutan dengan perkebunan, khususnya yang diketahui berada pada kawasan hutan dengan fungsi hutan produksi dan hutan produksi terbatas, dilakukan dengan proses tukar menukar kawasan hutan. Beberapa ketentuan umum tentang tukar menukar adalah tidak boleh mengurangi luas kawasan hutan tetap dan hanya dapat dilakukan apabila kawasan hutan yang dimohon berupa hutan produksi tidak dibebani izin penggunaan kawasan hutan dan pemanfaatan hutan. Selain itu, ada ketentuan tentang pentingnya mempertahankan daya dukung kawasan hutan yang layak dikelola, sehingga tukar menukar hanya dapat dilakukan pada wilayah dengan luas kawasan hutan paling sedikit $30 \%$ dari luas daerah aliran sungai, pulau, dan/atau provinsi dengan sebaran yang proporsional.

Salah satu isu penting dalam tukar menukar adalah tentang ketentuan lahan pengganti yang wajib diadakan pemohon sebagai kompensasi hilangnya kawasan hutan yang digunakan untuk perkebunan. Lahan pengganti harus memenuhi syarat-syarat kejelasan terkait letak, luas dan batas, serta terletak dalam daerah aliran sungai, provinsi atau pulau yang sama. Lahan pengganti juga harus bebas dari sengketa dan segala jenis pembebanan dan hak tanggungan. Ketentuan tentang keharusan letak lahan pengganti berbatasan langsung dengan kawasan hutan, seperti tertuang di dalam P.32/2010, dihilangkan melalui P.41/2012, mengingat kesulitan investor dalam memenuhi syarat tersebut. Ini sebagai salah satu bentuk kemudahan yang diberikan pemerintah dalam rangka peningkatan percepatan pelayanan tukar menukar kawasan hutan. Dalam Peraturan Menteri No. P.27/2014 yang mengubah lebih lanjut ketentuan tentang tukar menukar dari peraturan yang tersebut sebelumnya, persyaratan administrasi juga dipermudah dengan dibolehkannya rekomendasi berasal dari salah satu saja, yakni gubernur atau bupati terkait persetujuan atas kawasan hutan yang dimohon dan usulan lahan pengganti untuk dijadikan kawasan hutan.

Tukar menukar terkait dengan perkebunan kelapa sawit yang berada di provinsi atau pulau yang kawasan hutannya kurang dari 30\%, maka besarnya rasio paling sedikit adalah 1:2. Tetapi untuk wilayah dengan kawasan hutan masih di atas $30 \%$, maka rasio paling sedikit 1:1. Bagi provinsi yang tidak mempunyai areal bukan kawasan hutan yang cukup sebagai lahan pengganti, tetapi mempunyai kawasan hutan dengan fungsi hutan produksi yang dapat dikonversi, maka proses tukar menukar dapat dilakukan dengan mengubah fungsi hutan produksi yang dapat dikonversi menjadi hutan produksi tetap.

\subsection{Pola penyelesaian penguasaan dan pemanfaatan tanah dalam kawasan hutan oleh masyarakat}

Peraturan Presiden No. 88/2017 mengatur beberapa pola penyelesaian kasus-kasus masyarakat yang menguasai tahan garapan di dalam kawasan hutan, yang terjadi sebelum atau sesudah status kawasan hutan ditetapkan. Berdasarkan Peraturan tersebut, lahan garapan didefinisikan sebagai bidang tanah di dalam kawasan hutan yang dikerjakan dan dimanfaatkan oleh seseorang atau sekelompok orang yang 
dapat berupa sawah, ladang, kebun campuran dan/atau tambak. Sekalipun definisi tersebut tidak cukup jelas menegaskan apakah kebun sawit rakyat merupakan bagian dari tanah garapan, namun - seperti dijelaskan pada bagian selanjutnya - ada peluang untuk menyelesaikan kasus-kasus kebun sawit rakyat yang sudah terlanjur berada di dalam kawasan hutan. Sumardjono, Simarmata, \& Wibowo (2018) menyatakan bahwa kebun sawit termasuk lahan garapan sekalipun tidak secara eksplisit disebutkan di dalam peraturan tersebut, karena penggunaan kata 'dapat' dalam menentukan cakupan lahan garapan. Indikasi masuknya kebun sawit sebagai salah satu bentuk lahan garapan dapat dilihat dari definisi petani dengan salah satu bidangnya perkebunan seperti diatur pada Pasal 1(23) dan penegasan bahwa pelepasan HPK tidak produktif yang salah satunya diperuntukan bagi kebun rakyat, seperti diatur pada Pasal 3 (2) dan Pasal 13 (4c) Peraturan Menteri Lingkungan Hidup dan Kehutanan No. P.17/2018. ${ }^{19}$

Untuk melaksanakan ketentuan Pasal 18 (1) dan 19 (3) Peraturan Presiden No. 88/2017 yang mengatur pembentukan tim inventarisasi dan verifikasi penguasaan tanah dalam kawasan hutan, Menteri Koordinator Bidang Perekonomian mengeluarkan pedoman pelaksanaan tugas inventarisasi dan verifikasi penguasaan tanah, seperti dituangkan dalam Peraturan No. 3/2018. Pedoman tersebut menjadi acuan bagi Tim Inventarisasi dan Verifikasi Penguasaan Tanah dalam Kawasan Hutan (PTKH) dan pemerintah daerah serta pemangku kepentingan lainnya. ${ }^{20}$ Tugas tim adalah untuk melakukan sosialisasi, menerima pendaftaran secara kolektif, melakukan pendataan lapangan dan analisis terkait data fisik dan yuridis bidang-bidang tanah dan juga terkait aspek lingkungan, serta memberikan rekomendasi tentang pola atau skema penyelesaian yang dapat berupa pengeluaran bidang tanah dari kawasan hutan, pemukiman kembali, tukar menukar, atau pemberian akses pengelolaan hutan melalui program perhutanan sosial.

\subsubsection{Perubahan batas kawasan hutan dan objek reforma agraria}

Kasus-kasus masyarakat yang menguasai tanah garapan atau kebun sawit di dalam kawasan hutan berpeluang diselesaikan melalui (1) pelepasan kawasaan hutan dari HPK tidak produktif atau (2) perubahan batas kawasan hutan dari kawasan hutan produksi atau kawasan hutan lindung yang telah dikuasai, dimiliki, digunakan dan dimanfaatkan untuk permukiman, fasilitas umum dan/atau fasilitas sosial, dan lahan garapan. Lahan-lahan garapan di kawasan hutan yang sudah berupa kebun sawit yang dikuasasi dan dimanfaatkan oleh masyarakat masuk diselesaikan melalui mekanisme penyediaan TORA yang kedua. Sementara itu, kawasan hutan dari HPK tidak produktif yang dilepaskan dapat juga diperuntukan bagi kebun rakyat. ${ }^{21}$

Namun, persyaratannya adalah bahwa tanah garapan atau kebun sawit tersebut dikuasai oleh masyarakat sebelum kawasan hutan dimaksud ditunjuk. Jika penguasaan lahan tersebut terjadi setelah kawasan hutannya ditunjuk, maka tanah garapan dapat dikeluarkan dari kawasan hutan berfungsi produksi dan lindung, sepanjang penguasaan masyarakat atas lahan dimaksud sudah berlangsung lebih dari 20 tahun secara berturut-turut. Persyaratan lainnya adalah bahwa luas kawasan hutan di wilayah tersebut masih diatas $30 \%$ dari luas daerah aliran sungai, pulau atau provinsi. Tanah tersebut kemudian menjadi bagian tanah objek reforma agraria. Kriteria lainnya adalah tentang batas maksimal tanah yang dapat dimohon oleh perseorangan, yakni maksimal 5 ha. ${ }^{22}$

19 Peraturan Menteri Lingkungan Hidup dan Kehutanan No. P.17/MENLHK/SETJEN/KUM.1/5/2018 tentang Tata Cara Pelepasan Kawasan Hutan dan Perubahan Batas Kawasan Hutan untuk Sumber Tanah Objek Reforma Agraria (dikeluarkan pada 25 Mei 2018)

20 Peraturan Menteri Koordinator Bidang Perekonomian No. 3/2018 tentang pedoman pelaksanaan tugas tim investarisasi dan verifikasi penguasaan tanah dalam kawasan hutan, yang diterbitkan pada 30 April 2018

21 Pasal 2 (3), Pasal 3 (1) dan (2) Peraturan Menteri Lingkungan Hidup dan Kehutanan No. P.17/2018 tentang Tata Cara Pelepasan Tata Cara Pelepasan Kawasan Hutan dan Perubahan Batas Kawasan Hutan untuk Sumber Tanah Objek Reforma Agraria (dikeluarkan pada 25 Mei 2018)

22 Bab III Pendaftaran permohonan inventarisasi dan verifikasi penguasaan tanah dalam kawasan hutan yang tertuang dalam Peraturan Menteri Koordinator Bidang Perekonomian No. 3/2018 tentang pedoman pelaksanaan tugas tim investarisasi dan verifikasi penguasaan tanah dalam kawasan hutan (diterbitkan pada 30 April 2018) 
Tidak serta merta semua tanah garapan yang memenuhi persyaratan tersebut dapat langsung dikeluarkan dari kawasan hutan. Hanya tanah garapan yang sudah diidentifikasi sebagai sumber tanah objek reforma agraria (TORA) dan masuk di dalam Peta Indikatif Alokasi Kawasan Hutan untuk Penyediaan TORA yang ditetapkan Menteri, yang dapat dikeluarkan. ${ }^{23}$ Berdasarkan peta indikatif alokasi kawasan hutan untuk penyediaan sumber tanah objek reforma agraria (TORA) yang diterbikan Menteri Menteri Lingkungan Hidup dan Kehutanan pada April 2017, luas penyediaan TORA mencapai \pm 4.853 .550 ha tersebar di berbagai wilayah provinsi, yang berasal dari berbagai sumber. ${ }^{24}$ Sampai saat ini, angka luasan tersebut sudah mengalami dua kali pemutakhiran yang dituangkan di dalam SK Menteri Lingkungan Hidup dan Kehutanan (Tabel 5). ${ }^{25}$

Tabel 5. Sumber TORA sesuai SK Menteri Lingkungan Hidup dan Kehutanan No. 180/2017 dan revisi perubahannya

\begin{tabular}{llccc}
\hline \multirow{2}{*}{ No } & Kriteria Sumber TORA & \multicolumn{3}{c}{ Luas (ha) } \\
\cline { 3 - 5 } & SK No. 180 & SK No. 6979 & SK No. 3154 \\
\hline 1 & $\begin{array}{l}\text { Alokasi 20\% kebun untuk masyarakat dari pelepasan } \\
\text { kawasan hutan untuk perkebunan }\end{array}$ & 437.937 & 719.636 & 417.485 \\
2 & HPK tidak produktif & 2.169 .960 & 1.587 .421 & 1.834 .539 \\
3 & $\begin{array}{l}\text { Program pemerintah untuk pencadangan pencetakan } \\
\text { sawah baru }\end{array}$ & 65.363 & 71.027 & 67.028 \\
4 & Permukiman transmigrasi beserta fasilitasi sosial & 514.909 & 516.533 & 502.382 \\
& $\begin{array}{l}\text { dan fasilitasi umum yang sudah memperoleh } \\
\text { persetujuan prinsip }\end{array}$ & & & \\
5 & Permukiman, fasilitas sosial dan umum & 439.116 & 588.786 & 642.835 \\
6 & Lahan garapan sawah dan tambak rakyat & 379.227 & 358.928 & 366.504 \\
7 & $\begin{array}{l}\text { Pertanian lahan kering yang menjadi sumber mata } \\
\text { pencaharian utama masyarakat setempat }\end{array}$ & 847.038 & 1.015 .467 & 1.118 .965 \\
& & $4,853,550$ & 4.857 .797 & $\mathbf{4 . 9 4 9 . 7 3 8}$ \\
\hline
\end{tabular}

Sumber: (Direktorat Pengukuhan dan Penatagunaan Kawasan Hutan, 2018b)

Ada peluang cukup besar untuk menyelesaikan kasus-kasus tanah garapan atau kebun sawit yang dikuasai masyarakat melalui proses perubahan batas kawasan hutan. Tabel 5 menunjukkan dua sumber tanah potensial yang dapat dimanfaatkan untuk menyelesaikan kasus kebun sawit rakyat di dalam kawasan hutan, yang luasannya 2.252.024 ha atau mencakup 45,5\% dari total sumber TORA berdasarkan hasil revisi terbaru (SK 3154):

1. Sumber pertama adalah lahan-lahan yang diperuntukan untuk membangun kebun masyarakat, yang menjadi bagian dari kewajiban perusahaan dalam memenuhi ketentuan $20 \%$ dari luas kawasan hutan yang dilepaskan untuk dijadikan perkebunan perusahaan. Dalam hal ini, pembangunan kebun masyarakat dapat diarahkan pada lahan-lahan di kawasan hutan sekitar konsesi perusahaan yang sudah terlanjur ditanami sawit oleh masyarakat setempat, dengan prioritas diberikan kepada yang sudah memenuhi persyaratan yang ditetapkan.

2. Sumber kedua berasal dari lahan-lahan hasil pelepasan kawasan hutan dengan fungsi HPK yang sudah tidak produktif, yang luasannya secara nasional berdasar hasil pemutakhiran terakhir

23 Pasal 3 (3c) Peraturan Menteri Lingkungan Hidup dan Kehutanan No. P.17/MENLHK/SETJEN/KUM.1/5/2018 tentang Tata Cara Pelepasan Kawasan Hutan dan Perubahan Batas Kawasan Hutan untuk Sumber Tanah Objek Reforma Agraria

24 Surat Keputusan Menteri Lingkungan Hidup dan Kehutanan No. 180/MENLHK/SETJEN/KUM.1/4/2017 tentang peta indikator alokasi kawasan hutan untuk penyediaan sumber tanah objek reforma agraria (TORA)

25 No. 6979 da 3154. Revisi terhadap sumber tanah TORA didasarkan pada pertimbangan penyesuaian terhadap hasil tata batas kawasan hutan, peta rupabumi Indonesia, penafsiran citra resolusi tinggi, usulan dari berbagai pihak, dan rekomendasi dari Badan Pemeriksa Keuangan (Direktur Pengukuhan dan Penatagunaan Kawasan Hutan 2018) 
mencapai sekitar 1,8 juta ha. Sumber kedua ini memberi peluang lebih besar penyelesaian kasuskasus kebun sawit rakyat di kawasan hutan mengingat skala luasnya yang lebih besar.

Kasus-kasus perkebunan kelapa sawit rakyat di dalam kawasan hutan di Kalimantan Tengah dan Kalimantan Barat berpeluang diselesaikan melalui skema TORA. Tabel 6 menyajikan sumber TORA di kedua provinsi, berdasarkan SK 180 dan hasil pemutakhiran data terakhir (SK 3154).

Tabel 6. Luas areal indikatif TORA di Provinsi Kalimantan Barat dan Kalimantan Tengah

\begin{tabular}{|c|c|c|c|c|c|}
\hline \multirow{3}{*}{ No } & \multirow{3}{*}{ Kriteria Sumber TORA } & \multicolumn{4}{|c|}{ Luasan (ha) } \\
\hline & & \multicolumn{2}{|c|}{ Kalimantan Barat } & \multicolumn{2}{|c|}{ Kalimantan Tengah } \\
\hline & & SK 180 & SK 3154 & SK 180 & SK 3154 \\
\hline 1 & $\begin{array}{l}\text { Alokasi } 20 \% \text { untuk kebun masyarakat dari } \\
\text { pelepasan kawasan hutan untuk perkebunan }\end{array}$ & 28.859 & 27.316 & 97.869 & 100.059 \\
\hline 2 & $\begin{array}{l}\text { Hutan Produksi yang dapat DiKonversi } \\
\text { (HPK) tidak produktif }\end{array}$ & 18.731 & 17.661 & 542.913 & 328.845 \\
\hline 3 & $\begin{array}{l}\text { Program pemerintah untuk pencadangan } \\
\text { pencetakan sawah baru }\end{array}$ & 29.297 & 29.215 & 35.996 & 26.741 \\
\hline 4 & $\begin{array}{l}\text { Permukiman transmigrasi beserta fasilitas } \\
\text { sosial dan fasilitas umum yang sudah } \\
\text { memperoleh persetujuan prinsip }\end{array}$ & 5.852 & 5.852 & 61.062 & 57.869 \\
\hline 5 & $\begin{array}{l}\text { Permukiman, fasilitas sosial dan fasilitas } \\
\text { umum }\end{array}$ & 13.140 & 75.668 & 25.149 & 29.434 \\
\hline 6 & $\begin{array}{l}\text { Lahan garapan berupa sawah dan tambak } \\
\text { rakyat }\end{array}$ & 4.667 & 14.034 & 42.143 & 61.603 \\
\hline \multirow[t]{2}{*}{7} & $\begin{array}{l}\text { Pertanian lahan kering yang menjadi } \\
\text { sumber mata pencaharian utama masyarakat } \\
\text { setempat }\end{array}$ & 12.619 & 31.910 & 186.018 & 227.079 \\
\hline & Total & 113.166 & 201.656 & 991.149 & 831.630 \\
\hline
\end{tabular}

Sumber: SK Menteri LHK No. 180 dan No. 3154/2018 (Ditjen Planologi Kehutanan dan Tata Lingkungan 2018)

Berdasarkan hasil pemutakhiran (SK 3154), persentase luas indikatif TORA dari berbagai sumber yang dialokasikan untuk Kalimantan Tengah mencakup 16,8\% dari luas indikatof TORA nasional, sementara untuk Kalimantan Barat hanya sekitar 4\% saja (Tabel 6). Luasan potensial sumber TORA yang dapat diarahkan untuk menyelesaikan penguasaan lahan di kawasan hutan di Kalimantan Tengah adalah 428.904 ha yang bersumber dari alokasi 20\% kewajiban perusahaan dan HPK yang tidak produktif. Sementara itu, di Kalimantan Barat hanya 44.977 ha saja yang tersedia.

Berdasarkan hasil analisis spasial, dari total luas perkebunan kelapa sawit yang terindikasi masuk dalam kawasan hutan di Provinsi Kalimantan Tengah yang mencapai 894.841 ha, diketahui hanya sekitar 24.859 ha atau 2,8\% yang masuk ke dalam areal indikatif alokasi TORA berdasarkan data SK No. $180 .{ }^{26}$ Ternyata kebun sawit yang terindikasi di dalam kawasan hutan tersebar tidak hanya di kedua sumber potensial TORA tetapi juga di sumber TORA lainnya seperti di lahan garapan sawah dan tambak rakyat, permukiman transmigrasi (Tabel 7).

Lokasi-lokasi kebun sawit seperti disajikan pada Tabel 7 dapat dijadikan prioritas pertama untuk diselesaikan melalui TORA. Namun, untuk memperluas cakupan dan mengoptimalkan program

26 Berdasarkan hasil tumpang susun antara peta sebaran kebun sawit di dalam kawasan hutan dengan peta indikatif TORA menurut SK Menteri Lingkungan Hidup dan Kehutanan No. 180/2017. 
Tabel 7. Sebaran kebun sawit di kawasan hutan di Kalimantan Tengah di berbagai sumber TORA

\begin{tabular}{llc}
\hline No & Kriteria Sumber TORA & Luas (ha) \\
\hline 1 & Alokasi 20\% untuk kebun masyarakat dari Pelepasan Kawasan Hutan & 4.347 \\
& untuk Perkebunan & 7.951 \\
4 & Hutan Produksi yang dapat DiKonversi (HPK) tidak produktif & 6.301 \\
5 & Permukiman transmigrasi beserta fasilitas sosial dan fasilitas umum yang & 59 \\
6 & sudah memperoleh persetujuan prinsip & 4.399 \\
7 & Permukiman, fasilitas sosial dan fasilitas umum & 1.801 \\
& Pahan garapan berupa sawah dan tambak rakyat & $\mathbf{2 4 . 8 5 9}$ \\
\hline
\end{tabular}

Sumber: Hasil analisis spasial (2018)

reforma agraria, maka luas kebun sawit lainnya ( 869.982 ha), terutama yang benar-benar lahan garapan masyarakat (sebagai subjek prioritas TORA), dapat diusulkan dalam revisi peta indikatif penyediaan sumber TORA selanjutnya. Jika ditemukan kendala dari sisi persyaratan, prosedur dan teknis administrasi dalam penerapan skema TORA, maka perlu inovasi kebijakan yang lebih efektif dan efisien seperti land amnesty (dibahas lebih lanjut).

Luasan sumber TORA yang berasal dari alokasi $20 \%$ untuk kebun masyarakat dan HPK tidak produktif di setiap kabupaten di kedua provinsi disajikan pada Tabel 8.

Hasil analisis lebih lanjut dengan menumpangsusunkan luasan dan sebaran perkebunan kelapa sawit rakyat di berbagai fungsi hutan - yang diidentifikasi berdasarkan citra satelit - dengan peta sumber TORA menunjukkan adanya peluang penyelesaian kebun sawit dalam kawasan hutan di Kabupaten Kotawaringin Barat. Ada potensi areal indikatif sekitar 13.299 ha tanah yang berasal dari alokasi $20 \%$ untuk kebun masyarakat dan HPK tidak produktif disediakan melalui skema TORA untuk kabupaten tersebut (Tabel 8). Namun, berdasarkan hasil analisis spasial, dari 10.133 ha perkebunan kelapa sawit rakyat yang teridentifikasi berada di dalam kawasan hutan (Tabel 3), yang dapat diselesaikan melalui skema TORA hanya seluas 2.614 ha (Tabel 9) yang berasal sumber TORA semua kriteria. Sedangkan sisanya seluas 7.519 ha belum masuk dalam skema TORA.

Peta indikatif TORA senantiasa akan diperbarui secara periodik setiap 6 bulan sekali, dengan memperhatikan antara lain hasil penafsiran citra satelit resolusi tinggi dan usulan para pihak. Ada peluang penyelesaian kebun sawit rakyat di dalam kawasan hutan melalui skema TORA, sehingga prioritas dapat diarahkan pada kebun-kebun sawit rakyat yang sudah ada dengan harapan petani yang menguasainya dapat memperoleh bukti legalitas. Tapi perlu diketahui bahwa tidak seluruh lahan yang disediakan melalui skema TORA diperuntukkan bagi penyelesaian kebun sawit di dalam kawasan hutan tetapi juga untuk kepentingan lainnya.

\subsubsection{Skema perhutanan sosial}

Jika penguasaan lahan garapan terjadi setelah kawasan hutan ditunjuk dan kurang dari 20 tahun, maka pola penyelesaiannya dilakukan melalui pemberian akses pengelolaan hutan melalui program perhutanan sosial. Ini berlaku jika bidang tanah yang dikuasai berada pada kawasan hutan dengan fungsi lindung atau produksi pada provinsi dengan luas kawasan hutan kurang dari $30 \%$ dari luas daerah aliran sungai, pulau, dan/atau provinsi. Demikian juga, jika tanah garapan dan kebun sawit yang dikuasai pekebun terjadi di wilayah dengan luas kawasan hutannya lebih dari $30 \%$, maka pekebun diberikan opsi penyelesaian dalam bentuk akses pengelolaan hutan melalui program perhutanan sosial, jika mereka baru menguasai lahan tersebut kurang dari 20 tahun. 
Tabel 8. Sebaran sumber TORA di setiap kabupaten di Provinsi Kalimantan Tengah dan Kalimantan Barat

\begin{tabular}{|c|c|c|c|}
\hline \multirow[t]{2}{*}{ Provinsi/kabupaten } & \multicolumn{3}{|l|}{ Sumber TORA (ha) } \\
\hline & $\begin{array}{l}\text { Alokasi } 20 \% \text { untuk kebun } \\
\text { masyarakat dari pelepasan } \\
\text { kawasan hutan untuk perkebunan }\end{array}$ & $\begin{array}{l}\text { Hutan Produksi yang dapat } \\
\text { DiKonversi (HPK) tidak } \\
\text { produktif }\end{array}$ & Total \\
\hline Kalimantan Barat & 28.859 & 18.731 & 47.590 \\
\hline Kapuas Hulu & & 3.806 & 3.806 \\
\hline Kayong Utara & 63 & 281 & 344 \\
\hline Ketapang & 21.856 & 7.107 & 28.963 \\
\hline Kuburaya & 1.808 & 2.559 & 4.367 \\
\hline Melawi & & 1.652 & 1.652 \\
\hline Mempawah & & 638 & 638 \\
\hline Sambas & 1.240 & & 1.240 \\
\hline Sanggau & 3.893 & 1.333 & 5.226 \\
\hline Sintang & & 1.354 & 1.354 \\
\hline Kalimantan Tengah & 97.910 & 542.749 & 640.659 \\
\hline Barito Kuala & 1 & & 1 \\
\hline Barito Selatan & 1.772 & 16.148 & 17.920 \\
\hline Barito Timur & 8.082 & 7.544 & 15.626 \\
\hline Barito Utara & 6.565 & 121.175 & 127.739 \\
\hline Gunungmas & 21.277 & 82.982 & 104.259 \\
\hline Kapuas & 4.881 & 34.417 & 39.298 \\
\hline Katingan & 15.906 & 53.548 & 69.454 \\
\hline Kota Palangka Raya & 2.243 & 5.456 & 7.699 \\
\hline Kotawaringin Barat & 1.948 & 11.351 & 13.299 \\
\hline Kotawaringin Timur & 9.114 & 72.930 & 82.044 \\
\hline Lamandau & 10.001 & 40.291 & 50.292 \\
\hline Murung Raya & & 50.561 & 50.561 \\
\hline Pulang Pisau & 7.529 & 7.176 & 14.706 \\
\hline Seruyan & 3.430 & 35.982 & 39.412 \\
\hline Sukamara & 5.162 & 3.187 & 8.350 \\
\hline Total & 126.769 & 561.479 & 688.249 \\
\hline
\end{tabular}

Sumber: Analisis spasial berdasarkan data TORA SK Menteri Lingkungan Hidup dan Kehutanan No. 180/2017

Tabel 9. Luas dan sebaran perkebunan kelapa sawit rakyat di Kabupaten Kotawaringin Barat di berbagai wilayah sumber TORA

\begin{tabular}{|c|c|c|c|c|c|}
\hline \multirow[t]{2}{*}{ No } & \multirow[t]{2}{*}{ Kriteria Sumber TORA } & \multicolumn{4}{|c|}{ Kotawaringin Barat (ha) } \\
\hline & & APL & HP & HPK & Total \\
\hline 1 & $\begin{array}{l}\text { Alokasi } 20 \% \text { untuk kebun masyarakat dari pelepasan } \\
\text { kawasan hutan untuk perkebunan }\end{array}$ & 35.52 & & 577.48 & 612.99 \\
\hline 2 & Hutan Produksi yang dapat dikonversi (HPK) tidak produktif & & & 903.21 & 903.21 \\
\hline 4 & $\begin{array}{l}\text { Permukiman transmigrasi beserta fasilitas sosial dan fasilitas } \\
\text { umum yang sudah memperoleh persetujuan prinsip }\end{array}$ & 455.81 & 0.43 & 38.18 & 494.43 \\
\hline 5 & Permukiman, fasilitas sosial dan fasilitas umum & 0.19 & 12.42 & 628.56 & 641.17 \\
\hline \multirow[t]{2}{*}{7} & $\begin{array}{l}\text { Pertanian lahan kering yang menjadi sumber mata } \\
\text { pencaharian utama masyarakat setempat }\end{array}$ & & 91.29 & 362.66 & 453.94 \\
\hline & Total & 491.52 & 104.13 & 2.510 .09 & 3.105.74 \\
\hline
\end{tabular}

Sumber: Data primer dan Sumber TORA berdasarkan SK Menteri Lingkungan Hidup dan Kehutanan No. 180/2017 
Peraturan Menteri Lingkungan Hidup dan Kehutanan No. P.83/Menlhk/Setjen/Kum.1/10/2016 mendefinisikan perhutanan sosial sebagai sistem pengelolaan hutan lestari yang dilaksanakan dalam kawasan hutan negara atau hutan hak/hutan adat dengan menempatkan masyarakat setempat atau masyarakat hukum adat sebagai pelaku utama. Selain menyelesaikan permasalahan tenurial, penerapan pola perhutanan sosial dimaksudkan untuk meningkatkan kesejahteraan masyarakat sekaligus menjaga keseimbangan lingkungan dan dinamika sosial budaya. Perhutanan sosial dapat dilaksanakan dalam berbagai bentuk seperti hutan desa, hutan kemasyarakatan, hutan tanaman rakyat, hutan rakyat, hutan adat dan kemitraan kehutanan.

Perhutanan sosial dapat menjadi salah satu pola penyelesaian kasus-kasus penguasaan masyarakat terhadap kawasan hutan, yang sebagian sudah menjadi lahan garapan dan kebun kelapa sawit. Namun demikian, ketentuan yang tertuang dalam peraturan menteri secara tegas menyebutkan larangan bagi pemilik izin hutan desa, hutan kemasyarakatan, hutan tanaman rakyat, hutan adat dan kemitraan kehutanan untuk menanam kelapa sawit di areal hak atau izinnya. ${ }^{27}$ Namun, sebagai bagian dari ketentuan peralihan, jika dalam areal perhutanan sosial yang menjadi objek penyelesaian konflik telah ada tanaman sawit, maka pemilik izin masih diperbolehkan untuk memeliharanya sampai 12 tahun sejak masa tanam tetapi ada keharusan untuk menanam pohon berkayu sekurang-kurangnya 100 pohon per ha diantara tanaman sawit tersebut. ${ }^{28}$ Jika dalam proses identifikasi dan verifikasi ditemukan tanaman kelapa sawit berumur kurang dari tiga tahun maka tanaman sawit tersebut harus dimusnahkan, tetapi jika umurnya lebih dari 3 tahun, maka pemilik diperbolehkan memanfaatkannya sampai usia tanaman mencapai setengah daur. ${ }^{29}$

\subsubsection{Penanganan konflik}

Untuk menyelesaikan konflik tenurial yang melibatkan masyarakat termasuk masyarakat adat yang menguasai, mengelola, memanfaatkan dan menggunakan kawasan hutan, Menteri Lingkungan Hidup dan Kehutanan mengeluarkan peraturan No. P.84/Menlhk-Setjen/2015 tentang penanganan konflik tenurial kawasan hutan. Melalui peraturan tersebut, Menteri mengatur tata cara penyelesaian konflik yang didahului dengan permohonan, verifikasi oleh tim independen penanganan konflik tenurial kawasan hutan (tim IPKTKH), dan asesmen yang dilakukan oleh tim asesor. Hasil analisis tim asesor terdiri dari tiga usul penyelesaian yakni melalui mediasi, perhutanan sosial dan penegakan hukum.

\subsubsection{Penegakan hukum}

Pencegahan dan pemberantasan perusakan hutan sebenarnya sudah diatur di dalam Undang Undang No. 18/2013. Dalam peraturan perundang-undangan tersebut, perusakan hutan didefinisikan sebagai sebuah proses, cara atau perbuatan merusak hutan melalui kegiatan pembalakan liar, penggunaan kawasan hutan tanpa izin atau penggunaan izin yang bertentangan dengan maksud dan tujuan pemberian izin di dalam kawasan hutan yang telah ditetapkan, yang telah ditunjuk ataupun yang sedang diproses penetapannya oleh pemerintah. Tanpa merinci secara khusus asal muasal terjadinya kasus-kasus perkebunan kelapa sawit yang terlanjur berada di dalam kawasan hutan, penggunaan kawasan hutan secara tidak sah didefinisikan sebagai kegiatan terorganisasi yang dilakukan di dalam kawasan hutan untuk perkebunan tanpa persetujuan menteri.

Pencegahan perusakan hutan adalah segala upaya yang dilakukan untuk menghilangkan kesempatan terjadinya perusakan hutan. Adalah kewajiban pemerintah dan pemerintah daerah untuk melakukan pencegahan terjadinya perusakan hutan dengan cara meningkatkan koordinasi lintas sektor, memenuhi kebutuhan aparat pengaman hutan beserta sarana dan prasarananya, memberikan insentif bagi para pihak yang berjasa dalam menjaga kelestarian hutan dan menyediakan peta penunjukan kawasan hutan dan/

27 Pasal 56 (5) Peraturan Menteri Kehutanan No. P.83/Menlhk/Setjen/Kum.1/10/2016 tentang perhutanan sosial

28 Pasal 65 (h) Peraturan Menteri Kehutanan No. P.83/Menlhk/Setjen/Kum.1/10/2016 tentang perhutanan sosial

29 Disampaikan oleh Dr.Ir. Eka Widodo Soegiri MM., Direktur Penyelesaian Konflik Tenurial dan Hutan Adat (PKTHA), pada pertemuan focus group discussion tentang yang diselenggarakan pada Masalah Tenurial Sawit dan Skenario Penyelesaiannya, Hotel Akmani, Jakarta 29 Maret 2017 
atau koordinat geografis sebagai acuan bersama dalam menetapkan dasar yuridis batas kawasan hutan. Salah satu cara untuk mengurangi adanya peluang terjadinya perusakan hutan dalam bentuk dirambahnya kawasan hutan oleh perkebunan adalah dengan meningkatkan peran serta masyarakat. Melaui jejaring sosial dan kemitraan, masyarakat dapat berperan penting di dalam upaya pencegahan perambahan kawasan hutan dengan cara menyampaikan informasi kepada aparat penegak hukum dan meningkatkan kesadaran berbagai pihak tentang pentingnya kelestarian hutan dan dampak negatif perusakan hutan.

Dari uraian tersebut terlihat jelas bahwa kasus-kasus keterlanjuran perkebunan kelapa sawit yang berada di dalam kawasan hutan di berbagai wilayah, tidak hanya terjadi karena ketidaksadaran pelaku ketika merambah kawasan hutan dan kegiatan terorganisasi yang sengaja menggunakan kawasan hutan dengan memanfaatkan kelemahan aparat, tetapi juga karena dipicu oleh masalah maladministrasi ${ }^{30}$ yang dilakukan oleh penyelenggara negara. Pertanyaanya kemudian yang muncul adalah sejauh mana masyarakat berperan aktif di dalam mencegah terjadinya kasus keterlanjuran perkebunan di dalam kawasan hutan, yang juga akan terkait dengal soal sejauh mana masyarakat diberikan peran dan bagaimana proses penetapan sebuah keputusan berjalan, apakah sudah cukup transparan sehingga bisa diketahui oleh publik.

Ketentuan pidana yang diatur dalam Undang Undang No 18/2013 sudah cukup tegas yang dikenakan pada perseorangan, korporasi dan bahkan pejabat yang sekedar lalai atau sengaja membiarkan terjadinya penggunaan kawasan hutan tanpa izin. Individu yang dengan sengaja melakukan kegiatan perkebunan tanpa izin menteri di dalam kawasan hutan atau membawa alat berat untuk kegiatan perkebunan dan/atau mengangkut hasil perkebunan dari dalam kawasan hutan diancam dengan pidana penjara 3 sampai 10 tahun dan denda Rp1,5 sampai Rp5 miliar. ${ }^{31}$ Ketentuan pidana bagi pelaku korporasi diancam dengan pidana yang lebih berat yakni 8 sampai 20 tahun penjara dan Rp20 sampai Rp50 miliar denda jika mereka terbukti melakukan kegiatan perkebunan di atas kawasan hutan tanpa izin dan membawa alat berat ke dalamnya. Selain itu, jika yang pejabat lalai dalam melaksanakan tugas mencegah penggunaan kawasan hutan secara tidak sah diancam pidana 6 bulan sampai 5 tahun penjara dan denda Rp200 juta sampai Rp1 miliar. Pidana penjara dan denda semakin besar ancamannya jika pejabat memang sengaja membiarkan terjadinya penyerobotan kawasan hutan oleh kegiatan perkebunan, yakni pidana penjara 1 sampai 10 tahun dan denda Rp1 miliar sampai Rp10 milar.

\subsection{Kebijakan terkait lainnya}

Selain Kementerian Lingkungan Hidup dan Kehutanan, beberapa instansi pemerintah lainnya juga mengeluarkan kebijakan yang sekalipun tidak langsung terkait dengan penyelesaian tenurial perkebunan kelapa sawit di dalam kawasan hutan, tetapi berperan dalam mengatur dan mengantisipasi dampak negatif dari terjadinya gangguan yang diakibatkan tumpang tindih perkebunan dengan kawasan. Direktorat Jenderal Perkebunan mengeluarkan pedoman teknis penanganan gangguan dan konflik usaha perkebunan (Direktorat Jenderal Perkebunan 2016). Pedoman tersebut memberikan panduan bagi para pihak terutama aparat pemerintah di sektor perkebunan dalam menangani gangguan dan konflik dengan beragam tipologi dalam bentuk lahan, kehutanan dan non-lahan. Dalam hal lahan dan kehutanan, berbagai kasus gangguan dan konflik yang tercakup dalam pedoman tersebut antara lain: penggunaan tanah adat, belum selesaikan penetapan tata ruang wilayah daerah, penyerobotan areal perkebunan oleh masyarakat, tumpang tindih lahan perkebunan dengan kawasan pertambangan dan izin baru perkebunan, tuntutan masyarakat terhadap kebun plasma yang telah dijanjikan dan lahan perusahaan yang sudah habis masa HGU nya, lahan yang ditelantarkan, dan lokasi usaha perkebunan yang berada di dalam kawasan hutan akibat telah dilakukannya pembukaan lahan sebelum memperoleh persetujuan pelepasan kawasan hutan dari Menteri Lingkungan Hidup dan Kehutanan.

30 Ombudsman mendefinisikan maladministrasi sebagai perilaku atau perbuatan melawan hukum, melampaui wewenang, menggunakan wewenang untuk tujuan lain dari yang menjadi tujuan wewenang tersebut, termasuk kelalaian atau pengabaian kewajiban hukum dalam penyelenggaraan pelayanan publik yang dilakukan oleh penyelenggara negara dan pemerintahan yang menimbulkan kerugian materiil dan/atau in materiil bagi masyarakat dan orang perseorangan

31 Pasal 92 (1) Undang Undang No. 18/2013 
Salah satu tawaran penyelesaian yang lebih cepat dari sisi cut of date sesungguhnya bisa menggunakan Peraturan Menteri Agraria dan Tata Ruang/Kepala Badan Pertanahan Nasional No. 10 Tahun 2016 tentang tata cara penetapan hak komunal atas tanah masyarakat hukum adat dan masyarakat yang berada dalam kawasan tertentu. Yang dimaksud kawasan tertentu dalam peraturan ini adalah kawasan hutan atau perkebunan (Pasal 1, Ayat 2). Pemberian hak komunal kepada masyarakat hukum adat dilakukan setelah berbagai persyaratan dipenuhi. Persyaratan tersebut antara lain bahwa masyarakat tersebut menguasai secara fisik tanah paling tidak 10 tahun secara berturt- turut dan mereka masih menggantungkan pemenuhan kebutuhan sehari-hari secara langsung pada hasil bumi di wilayah tersebut, sehingga tanah dimaksud menjadi sumber utama kehidupan dan mata pencaharian masyarakat. Persyaratan lain adalah masih berjalannya kegiatan sosial dan ekonomi yang terintegrasi dengan kehidupan masyarakat.

Terjadinya kasus-kasus perkebunan kelapa sawit perusahaan yang berada di kawasan hutan sebenarnya dapat dicegah jika ketentuan-ketentuan di dalam Peraturan Menteri Agraria dan Tata Ruang/Kepala Badan Pertanahan Nasional No. 5/2015 tentang izin lokasi dan No. 7/2017 tentang pengaturan dan tata cara penetapan HGU diterapkan. Meskipun lahan untuk perkebunan yang digunakan dapat berasal dari berbagai sumber termasuk dari kawasan hutan, Pasal 9 Peraturan Menteri No. 7/2017 tersebut menegaskan bahwa sebelum HGU diterbitkan atas tanah tersebut, maka status kawasan hutannya harus terlebih dahulu diubah dan izin pelepasan diperoleh dari Menteri Lingkungan Hidup dan Kehutanan. Pasal 9 ayat $2 b$ menyatakan bahwa HGU dapat diberikan untuk areal yang di dalamnya terdapat daerah penyangga untuk kepentingan konservasi, dengan syarat pengelolaan, pemeliharaan dan pengawasannya menjadi tanggung jawab pemegang HGU.

\subsection{Kebijakan penyelesaian masalah tenurial di tingkat daerah}

Di tingkat daerah, beberapa pemerintah daerah telah mengeluarkan berbagai kebijakan untuk mencegah masuknya perkebunan kelapa sawit ke dalam kawasan hutan dan untuk menyelesaikan konflik tenurial terkait perkebunan kelapa sawit. Peraturan Daerah Provinsi Kalimantan Tengah No. 5/2011 tentang pengelolaan usaha perkebunan berkelanjutan telah mengatur beberapa ketentuan tentang keharusan investor untuk memperoleh izin pelepasan kawasan hutan terlebih dahulu sebelum IUP diterbitkan, ${ }^{32}$ apabila areal yang dimohonkan berasal dari kawasan hutan. Sekalipun tidak secara khusus menyangkut tumpang tindih perkebunan dengan kawasan hutan, peraturan daerah tersebut mengatur pembentukan forum komunikasi di tingkat provinsi dan kabupaten yang berperan dalam menyelesaikan persoalan-persoalan konflik dan gangguan usaha perkebunan. Untuk mengatasi konflik, pemberi izin juga mempunyai kewajiban untuk membentuk tim terpadu.

Pada 2010, misalnya, Gubernur Kalimantan Tengah membentuk tim pencegahan, penertiban, penanganan dan penyelesaian gangguan usaha perkebunan melalui Keputusan Gubernur No. 188.44/335/2010, dan kemudian pada 2012 membentuk tim pencegahan dan penyelesaian sengketa tanah/lahan melalui Keputusan Gubernur No 188.44/108/2012. Untuk menangani konflik secara terpadu di subsektor perkebunan, pada 2014 Gubernur Kalimantan Tengah kembali mengeluarkan Peraturan Gubernur No. 42/2014 yang intinya memberi pedoman bagi para pihak dalam mencegah, menangani, memediasi, melakukan pemulihan paska konflik dan membangun sistem informasi dan pengawasan terhadap berbagai konflik terkait perkebunan. Terdapat dua lembaga yang penting untuk membantu penanganan konflik, yakni forum komunikasi dan tim terpadu yang beranggotakan wakil-wakil dari pemerintah daerah, tokoh masyarakat, adat, pelaku usaha perkebunan, akademisi. Tim terpadu bertugas memfasilitasi upaya penyelesaian konflik termasuk memediasi para pihak yang terlibat konflik dan mengeluarkan rekomendasi kepada gubernur sebagai bahan pengambilan keputusan.

32 Pasal 42 Peraturan Daerah Kalimantan Tengah No. 5/2001 


\subsection{Kebijakan dan prospek penyelesaian masalah tenurial ke depan}

Pada tahun 2018 dikeluarkan setidaknya dua peraturan perundang-undangan yang menjadi dasar untuk lebih mengefektifkan penyelesaian tenurial, termasuk perkebunan kelapa sawit di kawasan hutan dan mempercepat pencapaian sasaran reforma agraria, yaitu pengentasan kemiskinan dan pemerataan ekonomi. Pertama, Instruksi Presiden No. 8/2018 tentang Penundaan dan Evaluasi Perizinan Perkebunan Kelapa Sawit serta peningkatan Produktivitas Perkebunan Kelapa Sawit, yang dikeluarkan pada 19 September 2018, diharapkan membuka peluang penyelesaian tumpang tindih perkebunan kelapa sawit di atas kawasan hutan melalui cara-cara yang lebih efektif. Setidaknya ada tiga kementerian teknis dan satu kementerian koordinator yang diberikan instruksi untuk melaksanakan kegiatan-kegiatan yang terkait dengan penyelesaian tenurial perkebunan kelapa sawit. Kementerian KLHK diinstruksikan untuk menunda pelepasan kawasan hutan, memverifikasi data perkebunan kelapa sawit yang telah dilepaskan melalui proses pelepasan atau tukar menukar, dan mengidentifikasi perkebunan kelapa sawit yang terindikasi berada dalam kawasan hutan. Berdasarkan hasil verifikasi dan evaluasi, salah satu opsi penyelesaian adalah dengan menetapkan langkah-langkah hukum atau tuntutan ganti rugi atas penggunaan kawasan hutan untuk perkebunan kelapa sawit.

Kedua, Peraturan Presiden No. 86/2108 tentang reforma agraria, yang diterbitkan pada 24 September 2018. Sementara Peraturan Presiden 88/2017 lebih diarahkan pada penyelesaian penguasaan tanah di kawasan hutan, Peraturan Presiden No. 86/2018 diterbitkan untuk mengatasi ketimpangan penguasaan dan pemilikan tanah dalam rangka menciptakan keadilan agraria. Peraturan presiden ini lebih menegaskan pengaturan tanah-tanah yang telah ditetapkan sebagai objek redistribusi tanah, termasuk antara lain tanah yang berasal dari pelepasan kawasan dan/atau hasil perubahan batas kawasan yang telah diselesaikan penguasaannya sesuai ketentuan peraturan perundang-undangan. Selain menetapkan batas maksimal 5 ha untuk lahan pertanian, dalam peraturan presiden tersebut juga ditetapkan tiga subjek reforma agraria yakni perseorangan, kelompok masyarakat dan badan hukum seperti yayasan, koperasi atau badan usaha milik desa. Subjek reforma agraria perseorangan antara lain petani gurem, petani penggarap, buruh tani dan buruh yang tidak memiliki tanah, guru honorer dan pegawai tidak tetap..$^{33}$

33 Pasal 12 ayat (3) Peraturan Presiden No. 86/2018 tentang reforma agraria 


\section{Evaluasi implementasi kebijakan penyelesaian tenurial perkebunan kelapa sawit}

Berdasarkan analisis hasil wawancara dan pengamatan lapangan, serta berbagai pandangan para pihak yang disampaikan pada rangkaian focus group discussion dan lokakarya, terdapat beberapa catatan penting yang dapat dijadikan bahan evaluasi pelaksanaan ke depan dari kebijakan penyelesaian kasus-kasus perkebunan kelapa sawit perusahaan yang terlanjur berada di kawasan hutan (pelepasan dan tukar menukar kawasan hutan) dan kasus-kasus penguasaan tanah berupa kebun sawit rakyat di kawasan hutan (TORA, perhutanan sosial).

\subsection{Pelepasan atau tukar menukar kawasan}

Kasus-kasus perkebunan perusahaan yang terlanjur berada di kawasan hutan diselesaikan melalui mekanisme pelepasan atau tukar menukar. Sampai Oktober 2018, perkebunan kelapa sawit yang telah diselesaikan melalui mekanisme PP 60/2012 dan PP 104/2015 tercatat hanya mencapai luas 186.220 ha yang diajukan oleh 42 unit perusahaan. Ini artinya bahwa baru sekitar 23\% saja dari seluruh luasan perkebunan perusahaan yang diindikasikan berada di dalam kawasan hutan, yang mencapai luasan 800.000 menurut data resmi dari Direktorat Jenderal Perkebunan.

Banyaknya kasus keterlanjuran yang tidak dapat diselesaikan karena sebagian besar pelaku usaha tidak dapat memenuhi kriteria yang ditetapkan Pasal 51 PP 104/2015 terutama kewajiban untuk menyediakan lahan pengganti bagi perkebunan yang berada di kawasan hutan dengan fungsi hutan produksi/hutan produksi terbatas. Diakui bahwa dalam praktiknya, sangat sulit bagi perusahaan untuk menyediakan lahan pengganti atas kawasan hutan yang akan dikonversi menjadi perkebunan sesuai syarat-syarat yang ditetapkan, sekalipun kriteria lahan pengganti sudah lebih dipermudah. Hal ini menyebabkan sebagian besar perusahaan belum sempat mengajukan permohonan pelepasan kawasan dan tukar menukar kawasan kepada Menteri KLHK sampai tenggat waktu yang telah ditetapkan, yakni tanggal 28 Desember 2016 (Direktorat Pengukuhan dan Penatagunaan Kawasan Hutan, 2018a).

Selain itu, sebagian perkebunan perusahaan ternyata ditemukan KLHK (2018) memang berada di dalam areal dengan status kawasan hutan menurut RTRWP dan bukan pada Kawasan Budidaya NonKehutanan (KBNK) atau Kawasan Pengembangan Produksi (KPP) atau Kawasan Pemukiman dan Pengembang Lainnya (KPPL), yang sebenarnya tidak memenuhi ketentuan di dalam Pasal 51 PP $104 / 2015$.

Keengganan sebagian pelaku usaha untuk mengajukan permohonan pelepasan kawasan dan tukar menukar disebabkan antara lain karena alasan bahwa kasus keterlanjuran terjadi bukan karena kesalahan pihak perusahaan, tetapi lebih karena ketidakkonsistenan aturan penetapan kawasan hutan berdasarkan RTWRK/P dan SK Menteri KLHK. ${ }^{34}$ Sampai saat ini belum ada mekanisme regulasi yang mengatur tata cara perusahaan mengajukan perizinan pelepasan atau tukar menukar setelah tenggat waktu tersebut. Kondisi ini, jika berlarut, tentu akan menciptakan ketidakpastian hukum dan investasi. Hal lain yang dianggap penting oleh pelaku usaha di dalam menghadapi permasalahan tenurial yang berlarut-larut ini adalah adanya pengakuan pemerintah terhadap keberadaan mereka.

34 Seperti disampaikan melalui diskusi kelompok dalam rangkaian FGD di kedua provinsi 
Instruksi Presiden No. 8/2018 secara khusus telah memberi mandat kepada Kementerian KLHK untuk memverifikasi data perkebunan kelapa sawit yang telah dilepaskan melalui proses pelepasan atau tukar menukar dan mengidentifikasi perkebunan kelapa sawit yang terindikasi berada dalam kawasan hutan. Ini memberi peluang dilakukannya verifikasi dan evaluasi terhadap perusahaan-perusahaan yang kebunnya berada di dalam kawasan hutan. Dengan melihat beragam tipologi perkebunan kelapa sawit perusahaan di dalam kawasan hutan, maka proses verifikasi dan evaluasi perlu diarahkan pada:

1. Lokasi keberadaan perkebunan perusahaan dan status kawasan hutan menurut RTRWK/P dan SK Menteri KLHK. Jika keberadaan perkebunan tersebut jelas-jelas berada di dalam areal yang statusnya menurut RTRWK/P maupun SK Menteri KLHK berada di dalam kawasan hutan, maka sanksi sesuai dengan UU No. 18/2013 tentang Pencegahan dan Pemberantasan Perusakan Hutan dapat diterapkan. Opsi penyelesaiannya adalah dengan menetapkan langkah-langkah hukum atau tuntutan ganti rugi atas penggunaan kawasan hutan untuk perkebunan kelapa sawit, karena adanya indikasi pelanggaran dan tidak diikutinya tahap-tahap prosedural penggunaan kawasan hutan. ${ }^{35}$ Namun, jika perkebunan yang diketahui berada di dalam kawasan hutan disebabkan karena inkonsistensi penetapan kawasan hutan menurut RTRWK/P dan SK Menteri KLHK, maka perlu dibuka kesempatan kedua (terakhir) bagi perusahaan untuk mengajukan permohonan pelepasan atau tukar menukar dengan mengamandemen Pasal 51 PP 104/2015 dengan batas waktu selama satu tahun. Salah satu argumen yang muncul adalah bahwa batas waktu yang ditetapkan Pasal 51 PP 104/2015 dianggap terlalu pendek dan berimplikasi berbeda bagi perusahaan-perusahaan dengan dukungan modal usaha skala besar dan kecil dalam memenuhi tata cara pemenuhan persyaratan yang ditetapkan.

2. Pemanfaatan areal dan kondisi hutan yang berada dalam konsesi perkebunan. Jika areal yang diklaim oleh perusahaan belum dikerjakan/dibangun perkebunan kelapa sawit dan/atau kondisi hutannya masih produktif, maka bagian dari areal tersebut mutlak harus dikembalikan sebagai kawasan hutan.

3. Sejauh mana komitmen pelaku usaha perkebunan bersangkutan terhadap Indonesian Sustainable Palm Oil (ISPO), yang dicerminkan melalui penilaian secara obyektif dan independen terhadap pemenuhan prinsip dan kriteria (a) legalitas usaha perkebunan, yakni kewajiban memfasilitasi pembangunan kebun masyarakat seluas $20 \%$, dan (b) pengelolaan dan pemantauan lingkungan, yakni upaya menyisihkan areal hutan dengan nilai konservasi tinggi.

Selain itu perlu juga dibuka kemungkinan penyelesaian kasus-kasus keterlanjuran dengan mengeluarkan suatu kebijakan dan mekanisme aturan yang baru, misalnya sewa pakai lahan, yang didasarkan pada prinsip-prinsip yang menguntungkan bagi negara tetapi tidak membebani pelaku usaha dan masyarakat (Direktorat Pengukuhan dan Penatagunaan Kawasan Hutan, 2018a). Usulan (Direktorat Jenderal Planologi Kehutanan dan Tata Lingkungan, 2016) tentang penetapan Penerimaan Negara Bukan Pajak (PNBP) sewa pakai sebesar Rp 1 juta per ha atas kawasan hutan yang dirambah pelaku usaha mungkin dapat dipertimbangkan kembali, disesuaikan dengan nilai saat ini dan dituangkan di dalam peraturan perundangan-undangan yang mengikat. Berdasar asumsi tersebut dan luas perkebunan di kawasan hutan 2,3 juta ha, penerimaan negara setiap tahunnya ditaksir mencapai Rp 27,6 triliun. Tentu saja, ketentuan sewa pakai harus diterapkan secara selektif dan sesuai dengan tipologi kasus perambahan perkebunan perusahaan.

\subsection{Tanah Objek Reforma Agraria (TORA)}

Dengan pertimbangan untuk mempertahankan kontribusi perkebunan rakyat terhadap produksi minyak sawit nasional dan memberikan legalitas kepada pekebun sawit agar bisa memenuhi persyaratan berkelanjutan, maka penting untuk melihat beberapa catatan tentang sejauhmana efektivitas reforma

35 Penegakan hukum merupakan salah satu langkah yang bisa diambil, tetapi diakui bahwa diperlukan energi yang besar untuk menempuh jalur tersebut. Biaya untuk penegakan hukum dengan cara membabat kebun sawit, misalnya, membutuhkan biaya Rp 4 juta per hektar (KLHK 2018, Santoso 2018). 
agraria melalui TORA di dalam menyelesaikan penguasaan kebun sawit dalam kawasan hutan oleh masyarakat. Pertama, peraturan perundang-perundangan yang ada belum menegaskan masuknya kebun sawit ke dalam kategori lahan garapan, sekalipun pengaturannya secara implisit sudah ada. Penegasan masuknya kebun sawit ke dalam kategori lahan garapan diperlukan agar memberikan landasan hukum yang kuat.

Kedua, di dalam mekanisme perubahan batas kawasan hutan, lahan garapan yang bisa diselesaikan harus dikuasai oleh masyarakat bersangkutan lebih dari 20 tahun secara berturut-turut. Kriteria tersebut tampaknya sulit untuk dipenuhi, terutama di wilayah-wilayah yang pengembangan perkebunan kelapa sawitnya belum berkembang lama. (Schoneveld et al., n.d.) menemukan bahwa di wilayah sampel di Kalimantan Tengah dan Kalimantan Barat, kebun sawit rakyat swadaya yang paling tua dan juga diperkirakan lama penguasaan lahannya oleh masyarakat, baru berumur 13 tahun. Dengan demikian, akan sulit bagi pekebun sawit di wilayah tersebut memenuhi kriteria waktu penguasaan ini dan menikmati manfaat kebijakan reforma agraria. Perlu dipertimbangkan untuk menetapkan lama waktu penguasaan lahan yang lebih pendek, misalkan 10 tahun dengan menyertakan kewajiban bagi pekebun untuk memenuhi prinsip dan kriteria ISPO bagi usaha kebun swadaya (misalnya dalam legalitas kebun, penerapan praktik-praktik pertanian yang baik, organisasi dan kewajiban mengelola dan memantau lingkungan). Dengan cara tersebut, pekebun selain memperoleh legalitas sekaligus juga didorong untuk memproduksi hasil sawit atau tandan buah segar yang memenuhi prinsip-prinsip minyak sawit berkelanjutan.

Ketiga, seperti yang dijelaskan sebelumnya, ada perbedaan antara lokasi TORA yang tertuang di dalam peta indikatif dengan lokasi-lokasi potensial lahan garapan, dalam hal ini kebun-kebun sawit rakyat, yang layak untuk diselesaikan melalui reforma agraria. Penyesuaian dan pemutakhiran data dan peta indikatif TORA masih perlu dilakukan, misalnya dengan melihat peta distribusi perkebunan kelapa sawit rakyat, agar lebih banyak lahan garapan yang bisa terakomodir. Perlu ada rekonsiliasi data peta dengan data survey lapangan dari berbagai lembaga dan organisasi yang aktif melakukan pemetaan lahan-lahan garapan di kawasan hutan yang dikuasai masyarakat yang layak diselesaikan. (Konsorsium Pembaruan Agraria, 2017)mengkritisi program TORA yang dinilai tidak sejalan dengan spirit reforma agraria sejati, karena penetapan lokasi TORA tidak berdasarkan atas inisiatif organisasi masyarakat sipil dan serikat-serikat tani yang berada di wilayah konflik agraria.

Keempat, ada sedikit peluang penyelesaian penguasaan kebun sawit rakyat di kawasan hutan melalui mekanisme pelepasan kawasan hutan dari HPK yang tidak produktif. Sekalipun kebijakan tersebut diarahkan salah satunya bagi kebun rakyat, ${ }^{36}$ namun subjek perorangan penerima TORA dari hasil pelepasan kawasan HPK tidak produktif tersebut telah ditetapkan secara ketat kriteria pekerjaannya. Masyarakat yang menjadi subjek penerima TORA adalah yang pekerjaannya sebagai petani gurem, penyewa tanah, petani penggarap, buruh tani, nelayan kecil, petambak garam kecil, guru honorer, pekerja harian lepas, buruh, pedagang informal dan pegawai negeri sipil yang tidak memiliki tanah. Dengan demikian, petani atau pekebun yang saat ini menguasai kebun sawit di dalam kawasan hutan tidak serta merta masuk di dalam kategori tersebut. Pemberian hak tenurial terutama dalam bentuk hak kepemilikan perlu diprioritaskan kepada orang perseorangan yang memang belum memiliki tanah dan benar-benar menyandarkan penghidupannya pada lahan yang berada dalam sengketa. Namun, untuk mengoptimalkan tujuan peningkatan produktivitas lahan, maka definisi penerima TORA dari hasil pelepasan kawasan HPK tidak produktif perlu diperluas agar mencakup petani atau pekebun yang menguasai lahan dengan luasan terbatas dengan kompetensi atau kemampuan mengelola lahan, sehingga resiko tanah terlantar nantinya akan bisa dikurangi.

36 Pasal 12 Peraturan Presiden No. 86/2018 tentang Reforma Agraria dan Pasal 3 (2c) Peraturan Menteri Lingkungan Hidup dan Kehutanan No. P.17/MENLHK/SETJEN/KUM.1/5/2018 tentang Tata Cara Pelepasan Kawasan Hutan dan Perubahan Batas Kawasan Hutan untuk Sumber Tanah Objek Reforma Agraria. 
Kelima, dalam menyelesaikan kasus-kasus kebun sawit rakyat yang berada di kawasan hutan, adalah sangat penting untuk memahami karakteristik dan keragaman tipologi pekebun. Dengan pemahaman tersebut, setiap upaya penerapan kebijakan penyelesaian penguasaan tanah oleh masyarakat di kawasan hutan akan lebih tepat sasaran. Dengan mengacu pada wilayah studi di Kalimantan Tengah dan Kalimantan Barat, (Schoneveld et al., n.d.) menemukan ada 6 tipologi pekebun swadaya, yakni (1) petani subsisten, (2) petani perintis atau early adopter, (3) pekerja migran, (4) petani migran, (5) petani usahawan (entrepreneur) dan (6) petani elit lokal.

Dengan mengacu pada penerima subjek TORA di atas, maka prioritas penyelesaian penguasaan tanah di kawasan hutan dapat diarahkan pada petani sawit yang masuk dalam kategori petani subsisten, petani perintis, pekerja dan petani migran yang rata-rata penguasaan kebunnya antara 4 ha sampai 5 ha. Setelah status tanahnya menjadi lebih jelas dan legal setelah melalui proses pelepasan kawasan HPK tidak produktif atau perubahan batas kawasan hutan, akan dilakukan penataan akses yang mencakup upaya-upaya peningkatan kapasitas kelembagaan dan keterampilan, pendampingan usaha, pemberian akses permodalan dan pemasaran, seperti diamanatkan di dalam Peraturan Presiden 86/2018. Dalam konteks mendukung produksi minyak sawit nasional, maka upaya-upaya tersebut perlu diarahkan pada bagaimana petani sawit dapat memenuhi kriteria keberlanjutan menurut ISPO maupun RSPO. Petani subsiten dan petani migran merupakan dua kelompok, yang menurut (Schoneveld et al., n.d.), perlu mendapat prioritas dukungan legal dan teknis karena lemahnya keterkaitan mereka dengan sektor swasta dan pasar, serta kerentanan dan ketergantungan penghasilannya yang sangat besar pada hasil kebun sawit.

Penguasaan kebun sawit di kawasan hutan oleh petani yang masuk ke dalam kategori petani usahawan dan elit lokal disarankan penyelesaiannya melalui proses penegakan hukum dengan menerapkan ketentuan-ketentuan pidana seperti diatur di dalam Undang Undang No. 18/2013 tentang Pencegahan dan Pemberantasan Perusakan Hutan. Kedua kelompok petani sawit tersebut menguasai rata-rata areal kebun antara 7 sampai 15 ha, dan mereka umumnya cukup bermodal dan cenderung melakukan pelanggaran dengan mengambil resiko membangun kebunnya di kawasan hutan melalui jual beli lahan ilegal (Jelsma et al., 2017; Potter, 2016; Schoneveld et al., n.d.). Tingkat absente dari kedua kelompok tersebut umumnya tinggi, dimana mereka mengakui sebagai pemilik, tetapi tidak tinggal tinggal di sekitar kebun sawit - ini mempersulit kedua kelompok petani ini untuk memenuhi kriteria subjek reforma agraria seperti ditetapkan pada Pasal 12 (2) Peraturan Presiden 86/2018 tentang keharusan bertempat tinggal di wilayah objek redistribusi. Schoneveld et al. (n.d.) lebih lanjut menggambarkan bahwa kelompok tani usahawan juga biasanya mempunyai usaha kecil-kecilan lainnya seperti membuka toko dan penjualan TBS, dan petani elit lokal merupakan petani yang cukup berada, berpendidikan dan secara politis mempunyai kedudukan dan pengaruh yang kuat. Penghasilan utama mereka bukan berasal dari hasil berkebun sawit.

\subsection{Perhutanan sosial}

Perhutanan sosial dipandang sebagai salah satu solusi di dalam menyelesaikan permasalahan penguasaan tanah, khususnya terkait dengan kebun sawit masyarakat di dalam kawasan hutan (Santoso, 2018). Namun, perhutanan sosial dengan ketentuan-ketentuannya yang berlaku saat ini tampaknya bukan merupakan solusi ideal jangka panjang untuk menyelesaikan kebun sawit masyarakat di kawasan hutan, terutama jika dilihat dari perspektif mendorong peran petani sawit dalam menopang produksi minyak sawit nasional secara berkelanjutan. Keharusan untuk mengganti dan memusnahkan tanaman sawit, jika diketahui umur tanaman kurang dari tiga tahun, dan diberikannya izin untuk tetap memelihara tanaman sawit hanya sampai 12 tahun sejak masa tanam atau setengah daur, menjadi kendala utama penerapan skema tersebut.

Sampai saat ini tidak ada catatan resmi tentang realisasi penyelesaian penguasaan tanah dalam bentuk kebun sawit melalui perhutanan sosial. Tergantung pada setiap kasus, dimana ada kelompok masyarakat yang menjadi objek skema perhutanan sosial dengan sadar akan mengikuti ketentuan 
penggantian tanaman tersebut demi memperoleh akses legal terhadap lahan yang mereka usahakan. Pada kasus lain, masyarakat akan secara rasional berpikir untuk terus mengusahakan kebun sawitnya karena pertimbangan rasional bahwa komoditas tersebut lebih cepat dan menguntungkan, misalnya dibanding kayu, dan tata niaga komoditas sawit yang lebih sederhana dibandingkan kayu.

Dalam hal ini, perhutanan sosial dapat menjadi strategi kompromistis dan tawaran solusi sementara untuk menyelesaikan penguasaan tanah dalam bentuk kebun sawit masyarakat yang terlanjur berada di dalam kawasan hutan. Dengan berjalannya waktu sebelum berakhirnya rotasi tanaman sawit yang diperbolehkan, akan ada evaluasi. Strategi kompromistis tersebut mungkin dapat dilakukan dengan strategi jangka benah seperti yang ditawarkan oleh UGM (2018) dimana kawasan hutan yang telah terlanjur dibuka masyarakat menjadi kebun sawit untuk dikembalikan menjadi hutan kembali, dengan memulihkan ekosistemnya sehingga menyerupai hutan alam. Masyarakat bisa tetap dapat mengusahakan kebun sawit tersebut tetapi dengan menerapkan pendekatan pengelolaan model agroforestri yang mengkombinasikan dengan tanaman lain guna meningkatkan produktivitas lahan dan biodiversitas. Melalui strategi tersebut, struktur yang awalnya monokultur menjadi heterokultur, dan tujuan aspek sosial berupa perbaikan pendapatan keluarga petani dan aspek ekologi berupa keragaman ekosistem dapat terpenuhi.

\subsection{Amnesti tanah: Opsi penyelesaian tenurial}

Kasus-kasus penguasaan tanah di dalam kawasan hutan berakar pada persoalan ekonomi, sosial dan politik yang rumit, dan upaya penegakan hukum untuk menyelesaikan kasus-kasus tersebut seringkali tidak membuahkan hasil dan justru menyulut reaksi kontraproduktif dari pihak-pihak yang terlibat. Upaya penyelesaian tenurial perkebunan kelapa sawit di dalam kawasan hutan perlu dikombinasikan dengan pengampunan atas tanah atau amnesti tanah (land amnesty) yang diharapkan dapat mengatasi keterbatasan-keterbatasan yang ada pada peraturan perundang-undangan yang berlaku saat ini. Usulan penerapan instrumen land amnesty diperkuat oleh para pihak yang menginginkan penyelesaian tenurial secara tuntas, seperti disampaikan melalui rangkaian FGD yang diselenggarakan di Provinsi Kalimantan Barat dan Kalimantan Tengah.

Dari sisi istilah, amnesty berasal dari Bahasa Latin yang berarti pemberiaan maaf atau pemaafan (Omadjohwoefe, 2011), atau keputusan yang dibuat pemerintah untuk memaafkan orang atau pihak-pihak, baik individu maupun kelompok, yang telah melakukan kegiatan ilegal dan keputusan untuk tidak memberikan hukuman (Federation for American Immigration Reform, 2014). Amnesty merupakan bentuk pelepasan dan pemafaan dari hukuman akibat tindakan-tindakan kriminal, perlawanan dan pemberontakan yang biasanya terjadi terhadap negara dan masyarakat. Biasanya, anmesty selalu didasarkan pada hukum dan mempunyai tenggat waktu tertentu untuk memberi peluang bagi yang bersangkutan untuk menerima pemaafan (Ekumaoko, 2013).

Dalam hal ini, land amnesty dapat menjadi satu upaya pengampunan bagi pihak-pihak yang menguasai tanah dan menjadikannya kebun sawit di kawasan hutan. Land amnesty dapat ditargetkan kepada perseorangan, kelompok masyarakat dan badan hukum, yang penerapannya beragam tergantung kondisi di sepanjang kontinum. Pada satu sisi ekstrim, amnesti diberikan kepada pihak-pihak yang menguasai tanah secara ilegal dalam kawasan hutan dengan membebaskan mereka dari sanksi hukum tetapi mensyaratkan mereka untuk membayar pajak-pajak yang belum dibayar, misalnya Pajak Bumi dan Bangunan (PBB). Setelah memenuhi kewajibannya, mereka diberi hak legal untuk mengelola tanah dalam batasan luasan dan waktu tertentu. Dalam kasus mereka yang terkena aturan batas penguasaan, mereka diwajibkan untuk menyerahkan kelebihan lahan kepada negara, sesuai peraturan perundang-undangan yang berlaku.

Pada titik ekstrem lainnya, amnesti dapat juga diberikan kepada pihak-pihak yang menguasai tanah secara ilegal dan negara memberikan hak legal pengelolaan kepada yang bersangkutan tanpa ada persyaratan memenuhi kewajiban-kewajiban, misalnya membayar pajak. Ini dengan kondisi bahwa 
tanah benar-benar murni dikelola masyarakat setempat dan menjadi sumber mata pencaharian masyarakat dan keluarganya.

Untuk menyelesaikan penguasaan tanah dalam bentuk kebun sawit masyarakat di kawasan hutan, penerapan land amnesty perlu dipersyaratkan dan ditetapkan tentang luasan dan kekompakan areal yang berada dalam satu hamparan dan tidak terpencar-pencar, status masyarakat lokal/adat, masa garapan, bentuk kelembagaan yang tepat, dan adanya dukungan pemerintah daerah dalam bentuk pemberian insentif dan bantuan pendanaan. Dalam hal luasan, diusulkan agar batas maksimal lahan yang menjadi objek land amnesty adalah 4 ha, dengan pertimbangan bahwa luasan 4 ha kebun sawit setidaknya dapat menopang kehidupan rumah tangga yang layak. Luasan tanah di atas batas 4 ha cenderung untuk pertanda ambisius dan bentuk keserakahan. ${ }^{37}$

Secara khusus, land amnesty sebagai sebuah terobosan dapat diterapkan untuk menjawab keterbatasan peraturan saat ini, misalnya, terhadap aturan TORA yang hanya diberian kepada penggarap lahan yang penguasaan lahannya lebih dari 20 tahun. Demi mewujudkan keadilan, kepastian usaha dan kemanfaatan, maka TORA perlu juga diberikan kepada subjek pekebun sawit yang sekalipun penguasaan lahannya kurang dari 20 tahun tetapi sangat berpotensi dalam meningkatkan produktivitas lahan dan mempraktikkan teknik-teknik pertanian yang berkelanjutan.

Apakah instrumen land amnesty justru akan mendorong semakin luasnya deforestasi dan ketidakadilan? Apa yang terjadi di Brazil dengan diterapkannya kebijakan land amnesty mungkin dapat menjadi pelajaran untuk penerapannya di Indonesia. Brazil menerapkan kebijakan land amnesty dengan memberikan pemaafan kepada petani kecil yang secara ilegal melakukan penggundulan hutan. Berdasarkan Undang Undang Kehutanan Brazil tahun 2012, ada sekitar 90\% dari lahan perdesaan yang dapat digolongkan masuk dalam kebijakan amnesty. Petani dengan dengan luas penguasaan tanah rata-rata 20 ha di bagian selatan Brazil sampai 440 ha di Amazon diberikan amnesti sepanjang deforestasi yang dikibatkan oleh mereka terjadi sebelum bulan Juli 2012. Sekalipun diklaim ada keberhasilan kebijakan tersebut di dalam memberikan kepastian legal untuk pemilik lahan dan lebih mendorong mereka berinvestasi dan menjaga hutan, masih ada perdebatan tentang apakah penerapan kebijakan tersebut justru memperluas deforestasi. Kebijakan yang disepakati pemerintah federal pada bulan Juli 2017 tersebut ditentang oleh organisasi lingkungan dan petani dengan alasan bahwa pemberian land amnesty hanya menguntungkan pemilik lahan skala besar dan para penebang pohon ilegal. ${ }^{38}$

Untuk menghindari terjadinya dampak negatif dari penerapan land amnesty tersebut, maka subjek penerima harus diikat dalam suatu perjanjian - seperti juga telah diatur bagi subjek reforma agraria $^{39}$ - di dalam memenuhi kewajiban dan menghindari larangan. Penerima land amnesty wajib menggunakan, mengusahakan dan memanfaatkan kebunnya sendiri secara produktif dan dengan teknik-teknik perkebunan yang baik dan berkelanjutan, tidak memperluas lahan dari yang sudah ditetapkan, wajib memelihara dan melestarikan sumberdaya alam dan hutan di atas tanah dan di sekitarnya, serta tidak mengalihkan hak tanpa izin dari pihak yang berwenang. Land amnesty juga harus diberikan kepada masyarakat atau kelompok masyarakat yang tepat dan tidak terindikasi terkait dengan pemodal, sehingga tujuan peningkatan kesejahteraan dan kemandirian ekonomi masyarakat lokal/adat dapat terwujud.

37 Berdasarkan pandangan para pihak yang disampaikan di dalam diskusi kelompok di Palangkaraya tanggal 4 April 2018

38 Human Right Watch 2017. Brazil: Envets of 2017. https://www.hrw.org/world-report/2018/country-chapters/ brazil\#f893a0

39 Pasal 24, Pasal 25 dan Pasal 26 Peraturan Presiden No. 86/2018 tentang Reforma Agraria, khususnya yang mengatur tentang kewajiban dan larangan penerima tanah objek reforma agraria 


\section{Kesimpulan dan rekomendasi}

Permasalahan tenurial perkebunan kelapa sawit di dalam kawasan hutan yang saat ini terindikasi mencapai 2,5 juta ha tidak terlepas dari sejarah perkembangan investasi kehutanan dan perkebunan dan pelepasan kawasan hutan untuk perkebunan. Praktik dan strategi pengadaan dan penguasaan lahan untuk perkebunan kelapa sawit baik yang melibatkan perusahaan atau badan usaha maupun masyarakat perseorangan, sekalipun sebagian melalui dilakukan melalui tata cara yang legal, telah berperan di dalam mendorong terjadinya perkebunan kelapa sawit di dalam kawasan hutan. Permasalahan tenurial ini juga disebabkan oleh lemahnya tata kelola yakni berubah-ubahnya kebijakan nasional dan daerah terkait dengan peruntukan tata ruang dan kawasan hutan, belum tuntasnya proses pengukuhan kawasan hutan, dan perambahan kawasan hutan oleh oknum-oknum yang sering dipicu penyebab utamanya oleh ketimpangan struktural dan keserakahan ekonomi. Sekalipun diakui ada peningkatan performa penyelesaian konflik tenurial melalui berbagai pilihan kebijakan, seperti pelepasan dan tukar menukar kawasan hutan, TORA, perhutanan sosial dan penegakan hukum, namun implementasi dari kebijakan-kebijakan tersebut masih belum efektif.

Hasil analisis spasial dari penelitian ini mengkonfirmasi keberadaan perkebunan kelapa sawit di dalam kawasan hutan yang beragam luasannya telah disampaikan berbagai pihak sebelumnya. Di Provinsi Kalimantan Tengah, ditemukan sekitar 894.841 ha perkebunan kelapa sawit yang berada dalam kawasan hutan, sementara di Kalimantan Barat jauh lebih kecil yakni sekitar 88.238 ha, yang tersebar umumnya di hutan produksi dan hutan produksi terbatas. Di tingkat kabupaten, perkebunan kelapa sawit juga ditemukan di dalam kawasan hutan seluas 10.133 ha di Kabupaten Kotawaringin Barat, 695 ha di Kabupaten Pulang Pisau, 1.828 ha di Kabupaten Landak, dan 79 ha di Kabupaten Sanggau, Sintang dan Kapuas Hulu.

Perlu dipertimbangkan beberapa hal berikut untuk lebih mengefektifkan implementasi kebijakan di dalam menyelesaikan penyelesaian tenurial perkebunan kelapa sawit di dalam kawasan agar permasalahannya tidak berlarut-larut dan tujuan kepastian investasi dan keadilan dapat tercapai.

1. Perusahaan-perusahaan perlu diberikan kesempatan kedua untuk mengajukan permohonan izin pelepasan kawasan atau tukar menukar dari Menteri KLHK dengan menetapkan batas waktu yang baru. Proses verifikasi dan evaluasi secara ketat perlu dilakukan dengan melihat tipologi perkebunan dalam hal lokasi, penyebab permasalahan, pemanfaatan areal dan komitmen terhadap pemenuhan prinsip dan kriteria minyak sawit berkelanjutan sesuai ISPO.

2. Untuk menyelesaikan penguasaan kebun sawit oleh masyarakat di kawasan hutan dan mendorong mereka untuk lebih produktif sekaligus menjaga kontribusi mereka terhadap produksi minyak sawit nasional secara berkelanjutan, maka ketentuan-ketentuan tentang TORA perlu disesuaikan. Lahan garapan untuk kebun sawit perlu lebih definisikan secara lebih jelas, prasyarat penguasaan lahan garapan perlu diperpendek, dan penyesuaian dan pemutakhiran peta indikatif TORA perlu direkonsiliasi dengan data survey dari berbagai pihak lain. Selain itu, penerima subjek TORA melalui mekanisme pelepasan kawasan hutan dari HPK yang tidak produktif perlu diperluas dengan mempertimbangkan subjek pemilik lahan sawit dengan kompetensi mengelola lahan produktif. Perlu juga dipahami karakteristik tipologi pekebun sawit dan memasukan petani subsisten, petani perintis, pekerja migran dan petani migran sebagai objek penerima TORA.

3. Penegakan hukum melalui penerapan Undang Undang No. 18/2013 dan ketentuan lain tentang tuntutan ganti rugi diterapkan bagi perusahaan-perusahaan yang- berdasarkan verifikasi dan evaluasi - perkebunan kelapa sawitnya berada dalam kawasan secara ilegal dan bukan karena inkonsisten kebijakan. Langkah-langkah hukum serupa perlu diterapkan bagi perkebunan rakyat yang masuk dalam kategori petani usahawan dan elit lokal.

4. Upaya penyelesaian tenurial perkebunan kelapa sawit di dalam kawasan hutan perlu dikombinasikan dengan pengampunan atas tanah atau amnesti tanah (land amnesty) yang 
diharapkan dapat mengatasi keterbatasan-keterbatasan yang ada pada peraturan perundangundangan yang berlaku saat ini. Land amnesty sebaiknya diprioritaskan kepada petani atau pekebun skala kecil yang kebun sawitnya secara de jure tidak bisa masuk atau menjadi bagian program reforma agraria.

5. Untuk mengurangi kerugian negara dari hilangnya potensi pajak penggunaan lahan di kawasan hutan oleh pelaku usaha, perlu juga dipertimbangkan pemberian legalisasi secara terbatas pada kebun-kebun yang terlanjur berada di kawasan hutan produksi, yang luasannya ditentukan berdasarkan kajian ekologi, sosial dan ekonomi. Selain batasan maksimal luas, misalkan $10 \%$ dari seluruh total luasan kawasan hutan produksi di lokasi tersebut, pelaku usaha juga diwajibkan memenuhi ketentuan perizinan lain yang relatif lebih ketat dibandingkan pelaku usaha perkebunan yang berada di luar kawasan hutan, seperti keharusan menyisihkan proporsi 'areal bernilai konservasi tinggi' yang lebih luas. Selain itu, tentunya perusahaan juga diwajibkan memenuhi kewajiban-kewajiban lain terkait membayar pajak bumi dan bangunan, sewa lahan, pungutan lain, seperti pungutan untuk dana konservasi. Untuk kasus-kasus perkebunan sawit yang berada di kawasan konservasi dan pelestarian alam diselesaikan melalui penegakan hukum atau skema perhutanan sosial dan kemitraan konservasi.

6. Kebijakan dan aturan yang terkoordinasi, terintegrasi dan tersinkronisasi antara sistem tata guna lahan, kehutanan dan tata ruang di tingkat pemerintah pusat (yang melibatkan kementerian terkait seperti Kementerian Agraria dan Tata Ruang, Kementerian Lingkungan Hidup dan Kehutanan) dan pemerintah daerah mutlak diperlukan untuk menyelesaikan dan menghindari terjadinya konflik agraria. Koordinasi, integrasi dan sinkronisasi tersebut mencakup seluruh tahap mulai dari perencanaan, pelaksanaan sampai pada pengawasan pemanfaatan lahan.

7. Rekonstruksi tata batas wilayah pedesaan dan penyusunan tata ruang desa dan tata guna lahannya yang berbasis ekologis bisa menjadi pilihan kebijkan untuk memitigasi konflik tenurial perkebunan di tingkat tapak. Kasus tumpang tindih lahan perkebunan perusahaan dengan lahanlahan pertanian atau pun ladang masyarakat desa, seperti kasus di Dabong Kabupaten Kubu Raya, Provinsi Kalimantan Barat akan bisa dihindari manakala tata ruang desa telah tersusun dengan baik. 


\section{Daftar pustaka}

Arts, B., Leroy, P., \& van Tatenhove, J. (2006). Political modernisation and policy arrangements: A framework for understanding environmental policy change. Public Organization Review, 6(2), 93-106. https://doi.org/10.1007/s11115-006-0001-4

AURIGA. (2017). Analisis ekspansi kebun sawit di hutan negara dan potensi kerugiannya. Disampaikan pada FGD Penyelesaian Masalah Tenurial Perkebunan Sawit menuju Pengelolaan Sawit Berkelanjutan, 29 Maret 2017 di Jakarta.

AURIGA. (2019). Pemetaan Tutupan Sawit Nasional. Disampaikan pada acara Konsultasi Pakar "Tipologi penguasaan lahan perkebunan sawit di dalam kawasan hutan dan strategi penyelesaiannya" tanggal 14 Februari 2019 di Jakarta.

Badan Pertanahan Nasional Provinsi Kalimantan Barat. (2017). Perkembangan hak guna usaha (HGU) untuk perkebunan sawit dan permasalahannya di Kalimantan Barat. Disampaikan pada FGD Penyelesaian Masalah Tenurial Perkebunan Sawit menuju Perkebunan Berkelanjutan, 29 Agustus 2017 di Pontianak.

Badrun, M. (2011). Milestone of change: Developing a nation through oil palm “PIR.” Jakarta: Directorate General of Estate Crops, Ministry of Agriculture of the Republic of Indonesia.

Beckert, B., Dittrich, C., \& Adiwibowo, S. (2014). Contested land : An analysis of multi-layered conflicts in Jambi Province, Sumatra, Indonesia. Austrian Journal of South-East Asian Studies, 7(1), 75-92. https://doi.org/10.14764/10.ASEAS-2014.1-6

Bronkhorst, E., Cavallo, E., van Dorth tot Medler, M.-M., Klinghammer, S., Smit, H. H., Gijsenbergh, A., \& van der Laan, C. (2017). Current practices and innovations in smallholder palm oil finance in Indonesia and Malaysia: Long-term financing solutions to promote sustainable supply chains. Info Brief CIFOR No 186. Bogor, Indonesia: CIFOR. https://doi.org/10.17528/cifor/006585006585

Budidarsono, S., Sirait, M. T., \& Pradhan, U. (2014). A new trend in palm oil production in the context of changing global demands: a portrayal of oil palm development in Riau Province, Sumatra, Indonesia. Brief No. 43. Bogor, Indonesia: World Agroforestry Centre (ICRAF), Southeast Asia Regional Program.

Colchester, M., \& Chao, S. (2011). Oil palm expansion in South East Asia: An overview. In M. Colchester \& S. Chao (Eds.), Oil palm expansion in South East Asia: Trends and implications for local communities and indigenous peoples (p. 264). Moreton-in-Marsh, England: Forest Peoples Programme.

Colchester, M., Jiwan, N., \& Chao, S. (2013). Conflict or consent? Oil palm expansion and community rights. Paper presented in Annual World Bank conference on land poverty, April 8-11 2013 at Washington D.C.

Cramb, R., \& Sujang, P. S. (2016). Oil palm smallholders and state policies in Sarawak. In R. Cramb \& J. F. McCarthy (Eds.), The Oil Palm Complex: Smallholders, Agribusiness and the State in Indonesia and Malaysia (pp. 247-282). Singapore: NUS Press. https://doi.org/10.2307/j. ctv1xz0km.12

Daemeter Consulting. (2015). Overview of Indonesian oil palm smallholder farmers: A typology of organizational models, needs, and investment opportunities. Bogor, Indonesia: Daemeter Consulting.

Deininger, K., \& Byerlee, D. (2011). Rising global interest in farmland: Can it yield sustainable and equitable benefits? Washington D.C.: The World Bank. https://doi.org/10.1596/978-0-8213-8591-3

Dinas Perkebunan Provinsi Kalimantan Barat. (2017). Kebijakan daerah untuk mendukung pengelolaan sawit berkelanjutan dari aspek legalitas dan produktivitas. Disampaikan pada FGD Penyelesaian Masalah Tenurial Perkebunan Sawit Menuju Pengelolaan Sawit Berkelanjutan, 29 Agustus 2017 di Pontianak.

Direktorat Jenderal Perkebunan. (2015). Statistik Perkebunan Indonesia 2014-2016: Kelapa Sawit. Jakarta, Indonesia: Direktorat Jenderal Perkebunan, Kementerian Pertanian. 
Direktorat Jenderal Perkebunan. (2016). Pedoman teknis penanganan gangguan dan konflik usaha perkebunan tahun 2016. Jakarta, Indonesia: Direktorat Jenderal Perkebunan, Kementerian Pertanian.

Direktorat Jenderal Perkebunan. (2017). Dukungan pendanaan bagi peningkatan produktivitas kelapa sawit nasional serta peningkatan kesejahteraan petani sawit. Disampaikan pada FGD Optimalisasi dana perkebunan kelapa sawit untuk mewujudkan pengelolaan sawit berkelanjutan, 30 Maret 2017 di Jakarta.

Direktorat Jenderal Perkebunan. (2018a). Komitmen perbaikan sawit Indonesia. Disampaikan pada Rembug Nasional Petani Kelapa Sawit Indonesia, 28 November 2018 di Jakarta.

Direktorat Jenderal Perkebunan. (2018b). Prakondisi ISPO perkebunan. Disampaikan pada Lokakarya Nasional Sawit Rakyat menuju ISPO, 19 Maret 2018 di Jakarta.

Direktorat Jenderal PHKA. (2012). Progress kegiatan PHKA dalam rangka penurunan emisi di sektor kehutanan. Disampaikan pada Workshop Identifikasi Kegiatan di Sektor Kehutanan yang Berpotensi Dalam Penurunan Emisi, Peningkatan Serapan dan Simpanan Karbon, 20 November 2012 di Bogor.

Direktorat Jenderal Planologi Kehutanan dan Tata Lingkungan. (2016). Penyelesaian (non litigasi) pelanggaran pemanfaatan dan penggunaan kawasan hutan secara tidak sah. Jakarta, Indonesia.

Direktorat Penelitian dan Pengembangan Kedeputian Bidang Pencegahan KPK RI. (2016). Kajian sistem pengelolaan komoditas kelapa sawit. Jakarta, Indonesia.

Direktorat Pengukuhan dan Penatagunaan Kawasan Hutan. (2018a). Kebijakan penyelesaian masalah tenurial perkebunan kelapa sawit di kawasan hutan. Disampaikan pada Lokakarya Linking science to policy: Peran penelitian dalam mendorong upaya penyelesaian tenurial sawit di kawasan hutan, 22 November 2019 di Bogor, Indonesia. Bogor, Indonesia.

Direktorat Pengukuhan dan Penatagunaan Kawasan Hutan. (2018b). Revisi II peta indikatif alokasi kawasan hutan untuk penyediaan sumber TORA. Disampaikan pada FGD Pemutakhiran peta indikatif penyediaan sumber TORA revisi II berdasarkan SK Menteri LHK 3154 tahun 2018, 6-8 Juni 2018 di Bogor.

Djajapertjunda, S. \& Djamhuri, E. (2013). Hutan dan kehutanan Indonesia dari masa ke masa. Bogor, Indonesia: IPB Press.

Ekumaoko, C. E. (2013). The amnesty question in post conflict Niger Delta and peace-building. Arabian Journal of Business and Management Review (OMAN Chapter), 2(10), 1-12.

Federation for American Immigration Reform. (2014). Defining amnesty for the factually impaired. FAIR Issue Brief. Washington D.C.: FAIR.

Gingold, B. (2010). Degraded land, sustainable palm oil, and Indonesia's future. Retrieved December 5, 2017, from http://www.wri.org/stories/2010/07/degraded-land-sustainable-palm-oil-and-indonesias-future

Hall, D. (2011). Land grabs, land control, and Southeast Asian crop booms. Journal of Peasant Studies, 38(4), 837-857. https://doi.org/10.1080/03066150.2011.607706

Jelsma, I., Schoneveld, G. C., Zoomers, A., \& van Westen, A. C. M. (2017). Unpacking Indonesia's independent oil palm smallholders: An actor- disaggregated approach to identifying environmental and social performance challenges. Land Use Policy, 69, 281-297. https://doi.org/10.1016/j. landusepol.2017.08.012

Kartodihardjo, H. (2008). Perlindungan dan perebutan ruang: Apa prioritas restrukturisasi kehutanan? In Bahan Diskusi FORCI IPB (pp. 1-3). Bogor, Indonesia: IPB.

Kementerian Kehutanan RI. (2011). Peraturan Menteri Kehutanan RI No. P.49/Menhut-II/2011 tentang Rencana Kehutanan Tingkat Nasional (RKTN) tahun 2011-2030. Indonesia.

Koalisi Masyarakat Sipil Kalimantan Barat. (2015). Potret perkebunan kelapa sawit Kalimantan Barat: Merusak bumi, menuai korupsi. Policy Brief. Kalimantan Barat: Koalisi Masyarakat Sipil Kalimantan Barat.

Kompas. (2015). Produksi CPO pada 2020 capai 40 juta ton. Retrieved December 4, 2017, from https:// ekonomi.kompas.com/read/2015/08/06/151118626/Produksi.CPO.Pada.2020.Capai.40.Juta.Ton

Kompas. (2016). Kemitraan, modus perusahaan sawit untuk menghindari pajak? Retrieved December 5, 2017, from https://regional.kompas.com/read/2016/10/19/15182931/kemitraan.modus. perusahaan.sawit.untuk.menghindari.pajakKompas. (2017). Gubernur Kalteng sebut 17 PMA perkebunan di wilayahnya ilegal. Retrieved December 5, 2017, from https://regional.kompas.com/ read/2017/06/22/07165051/gubernur.kalteng.sebut.17.pma.perkebunan.di.wilayahnya.ilegal 
Konsorsium Pembaruan Agraria. (2017). KPA persiapkan lokasi prioritas reforma agraria dan sistem perkebunan sawit yang berkeadilan. Retrieved January 2, 2019, from https://perkumpulanwallacea. wordpress.com/2017/11/14/kpa-persiapkan-lokasi-prioritas-reforma-agraria-dan-sistemperkebunan-sawit-yang-berkeadil...

Krishna, V. V., Kubitza, C., Pascual, U., \& Qaim, M. (2017). Land markets, property rights, and deforestation: Insights from Indonesia. World Development, 99, 335-349. https://doi.org/10.1016/j. worlddev.2017.05.018

Lee, J. S. H., Abood, S., Ghazoul, J., Barus, B., Obidzinski, K., \& Koh, L. P. (2014). Environmental impacts of large-scale oil palm enterprises exceed that of smallholdings in Indonesia. Conservation Letters, 7(1), 25-33. https://doi.org/10.1111/conl.12039

Li, T. M. (2017). Intergenerational displacement in Indonesia's oil palm plantation zone. Journal of Peasant Studies, 44(6), 1160-1178. https://doi.org/10.1080/03066150.2017.1308353

McCarthy, J. F., Gillespie, P., \& Zen, Z. (2012). Swimming upstream: Local Indonesian production networks in "globalized" palm oil production. World Development, 40(3), 555-569. https://doi. org/10.1016/j.worlddev.2011.07.012

McCarthy, J. F., \& Zen, Z. (2016). Agribusiness, agrarian change, and the fate of oil palm smallholders in Jambi. In R. Cramb \& J. F. Mccarthy (Eds.), The oil palm complex: smallholders, agribusiness and the state in Indonesia and Malaysia (pp. 109-154). Singapore: NUS Press. https://doi. org/10.2307/j.ctv1xz0km.9

Molenaar, J. W., Persch-Orth, M., Lord, S., Taylor, C., \& Harms, J. (2013). Diagnostic study on Indonesian oil palm smallholders: Developing a better understanding of their performance and potential. Jakarta, Indonesia.

Myers, R., Sanders, A. J. P., Larson, A. M., Prasti, R. D. ., \& Ravikumar, A. (2016). Analyzing multilevel governance in Indonesia: Lessons for REDD+ from the study of land-use change in Central and West Kalimantan (CIFOR Working Paper 202). Bogor, Indonesia. https://doi.org/10.17528/ cifor/006058

Omadjohwoefe, O. S. (2011). Amnesty initiative and the dilemma of sustainable development in the Niger Delta Region of Nigeria. Journal of Sustainable Development, 4(4), 249-258. https://doi. org/10.5539/jsd.v4n4p249

Pacheco, P., Schoneveld, G., Dermawan, A., Komarudin, H., \& Djama, M. (2018). Governing sustainable palm oil supply: Disconnects, complementarities, and antagonisms between state regulations and private standards. Regulation and Governance. https://doi.org/10.1111/rego.12220

Paoli, G. D., Gillespie, P., Wells, P. L., Havoni, L., Sileuw, A., Franklin, N., \& Schweithelm, J. (2013). Oil palm in Indonesia: Governance, decision making and implications for sustainable development: Summary for policy makers and practitioners. Jakarta, Indonesia: The Nature Conservancy.

Potter, L. (2016). How can the people's sovereignty be achieved in the oil palm sector? Is the plantation model shifting in favour of smallholders? In J. McCarthy \& K. Robinson (Eds.), Land and Development in Indonesia: Searching for the People's Sovereignty (pp. 315-342). ISEAS - Yusof Ishak Institute.

Prabowo, D., Maryudi, A., Senawi, \& Imron, M. A. (2017). Conversion of forests into oil palm plantations in West Kalimantan, Indonesia: Insights from actors' power and its dynamics. Forest Policy and Economics, 78, 32-39. https://doi.org/10.1016/j.forpol.2017.01.004

Pusat Kebijakan Kerjasama Perdagangan Internasional. (2015). Analisis strategi Indonesia untuk meningkatkan akses pasar produk crude palm oil (CPO) Indonesia ke Amerika Serikat. Jakarta, Indonesia.

Roundtable on Sustainable Palm Oil. (2016). RSPO Smallholders Definition. Retrieved January 9, 2019, from https://www.rspo.org/smallholders/rspo-smallholders-definition

Santoso, H. (2018). Penataan kebun sawit rakyat di dalam kawasan hutan: Persiapan menuju sertifikasi ISPO. Jakarta, Indonesia. Retrieved from http://revampingispo.com/publikasi/DownloadFile/17/ Penataan-Kebun-sawit-Rakyat-di-dalam-kawasan-hutan

Schoneveld, G., van der Harr, S., Ekowati, D., Andrianto, A., Komarudin, H., Okarda, B., \& Pacheco, P. (n.d.). Certification, good agricultural practice and smallholder heterogeneity: The differentiated performance of independent oil palm farmers in Indonesian Borneo. Submitted to Global

Environmental Change Journal. 
Semedi, P., \& Bakker, L. (2014). Between land grabbing and farmers' benefits: Land transfers in West Kalimantan, Indonesia. The Asia Pacific Journal of Anthropology, 15(4), 376-390. https://doi.org/ 10.1080/14442213.2014.928741

Setiawan, E. N., Maryudi, A., Purwanto, R. H., \& Lele, G. (2016). Opposing interests in the legalization of non-procedural forest conversion to oil palm in Central Kalimantan, Indonesia. Land Use Policy, 58, 472-481. https://doi.org/10.1016/j.landusepol.2016.08.003

Setiawan, E. N., Maryudi, A., Purwanto, R. H., \& Lele, G. (2017). Konflik tata ruang kehutanan dengan tata ruang wilayah (Studi kasus penggunaan kawasan hutan tidak prosedural untuk perkebunan sawit Provinsi Kalimantan Tengah). BHUMI: Jurnal Agraria Dan Pertanahan, 3(1), 51-66. https://doi.org/10.31292/jb.v3i1.89

Setra, M. S. (2013). Indigenous peoples in Indonesia: The struggle for "legal" recognition. Disampaikan pada Konferensi Scaling Up Strategies to Secure Community Land and Resource Rights, 19-20 September 2013 di Interlaken. Interlaken. Retrieved from http://www. rightsandresources.org/documents/files/doc_6343.pdf

Simmons, P., Winters, P., \& Patrick, I. (2005). An analysis of contract farming in East Java, Bali, and Lombok, Indonesia. Agricultural Economics, 33, 513-525. https://doi.org/10.1111/j.15740864.2005.00096.x

Subarudi, \& Ginoga, K. L. (2014). Alternatif solusi konflik kehutanan versus kebun kelapa sawit: Sebuah pembelajaran bagi sektor kehutanan. In I. Hakim \& L. R. Wibowo (Eds.), Hutan untuk rakyat: Jalan terjal reforma agraria di sektor kehutanan (p. 476). Yogyakarta, Indonesia: LKiS Yogyakarta.

Sulaeman, F. (2009). Sejarah perkebunan kelapa sawit di Kalimantan Tengah. Retrieved December 10, 2017, from http://kalteng.go.id/ogi/viewarticle.asp?ARTICLE_id=969

Sumardjono, M. S. W., Simarmata, R., \& Wibowo, R. A. (2018). Penyelesaian masalah penguasaan dan pemanfaatan kawasan hutan untuk perkebunan sawit rakyat. Laporan Kajian Hukum. Jakarta, Indonesia: Yayasan Kehati.

Susanti, A. (2016). Oil palm expansion in Riau province, Indonesia: Serving people, planet and profit? Utrecht University, Faculty of Geosciences.

Tempo. (2016). 1 , 5 juta hektare lahan sawit di Kalteng diduga ilegal. Retrieved December 5, 2017, from https://nasional.tempo.co/read/774457/15-juta-hektare-lahan-sawit-di-kalteng-diduga-ilegal

UGM. (2018). UGM tawarkan rekomendasi atasi polemik tanaman sawit di kawasan hutan. Retrieved January 2, 2019, from https://ugm.ac.id/id/news/17239-ugm.tawarkan.rekomendasi.atasi.polemik. tanaman.sawit.di.kawasan.hutan

WALHI. (2017). Konflik tenurial dan penyelesaiannya. Disampaikan pada FGD Penyelesaian Masalah Tenurial Perkebunan Sawit menuju Perkebunan Berkelanjutan, 18 Juli 2017 di Palangka Raya.

Wicke, B., Sikkema, R., Veronika, D., \& Faaij, A. (2011). Exploring land use changes and the role of palm oil production in Indonesia and Malaysia. Land Use Policy, 28(1), 193-206. https://doi. org/10.1016/j.landusepol.2010.06.001

Winrock International. (2017). The key characteristics of independent smallholders in the context of sustainable palm oil: Profile Bengkalis and Siak District, Riau; Ketapang and Kubu Raya District, West Kalimantan; and North Konawe District, Southeast Sulawesi. Aliansi Sawit Lestari Indonesia (ASLI) Project Report. Winrock, USAID, SPKS.

Zen, Z., Barlow, C., Gondowarsito, R., \& McCarthy, J. F. (2016). Interventions to promote smallholder oil palm and socio-economic improvement in Indonesia. In R. Cramb \& J. F. McCarthy (Eds.), The oil palm complex: smallholders, agribusiness and the state in Indonesia and Malaysia (pp. 78-108). Singapore: NUS Press. https://doi.org/10.2307/j.ctv1xz0km.8 



\section{DOI: $10.17528 /$ cifor $/ 007337$}

Working Paper CIFOR berisi hasil penelitian tahap awal atau lanjut, yang merupakan isu penting terkait hutan tropis, dan perlu dipublikasikan pada waktu yang tepat. Makalah tersebut dibuat untuk menginfomasikan sekaligus mendorong dilakukannya pembahasan. Isinya telah ditinjau secara internal, tetapi belum melewati proses tinjauan sesama rekan dari luar yang memakan waktu lebih lama.

Paper ini mendiskusikan fenomena perkebunan sawit yang berada secara ilegal di dalam kawasan hutan dengan studi kasus di Kalimantan Tengah dan Kalimantan Barat. Melalui metode wawancara mendalam, diskusi kelompok terfokus dan lokakarya, penelitian dilakukan sepanjang tahun 2017 dengan menyoroti isu-isu seputar tenurial terkait sektor kehutanan dan perkebunan kelapa sawit. Analisis dilakukan dengan mereview sejarah perkembangan investasi kehutanan dan perkebunan, dan melihat bagaimana praktik dan strategi para aktor di dalam menguasai dan memperluas lahan perkebunan kelapa sawit. Juga dianalisis bagaimana efektivitas implementasi kebijakan seperti pelepasan dan tukar menukar kawasan hutan untuk penggunaan non kehutanan, moratorium perizinan sawit, reforma agraria atau Tanah Obyek Reforma Agraria (TORA) dan perhutanan sosial di dalam menyelesaikan masalah penguasaan lahan. Paper menawarkan beberapa opsi kebijakan dan terobosan dalam upaya mendorong penyelesaian masalah tenurial perkebunan sawit. penelitian inovatif, mengembangkan kapasitas para mitra dan terlibat secara aktif dalam dialog dengan semua pemangku kepentingan untuk memberi masukan terhadap berbagai kebijakan dan praktik yang memengaruhi hutan dan masyarakat. CIFOR merupakan bagian dari Pusat Penelitian CGIAR, dan memimpin Program Penelitian CGIAR pada Hutan, Pohon dan Wanatani (FTA). Kantor pusat kami berada di Bogor, Indonesia, dengan kantor wilayah di Nairobi, Kenya; Yaounde, Kamerun; Lima, Peru dan Bonn, Jerman.

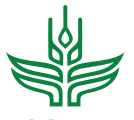

